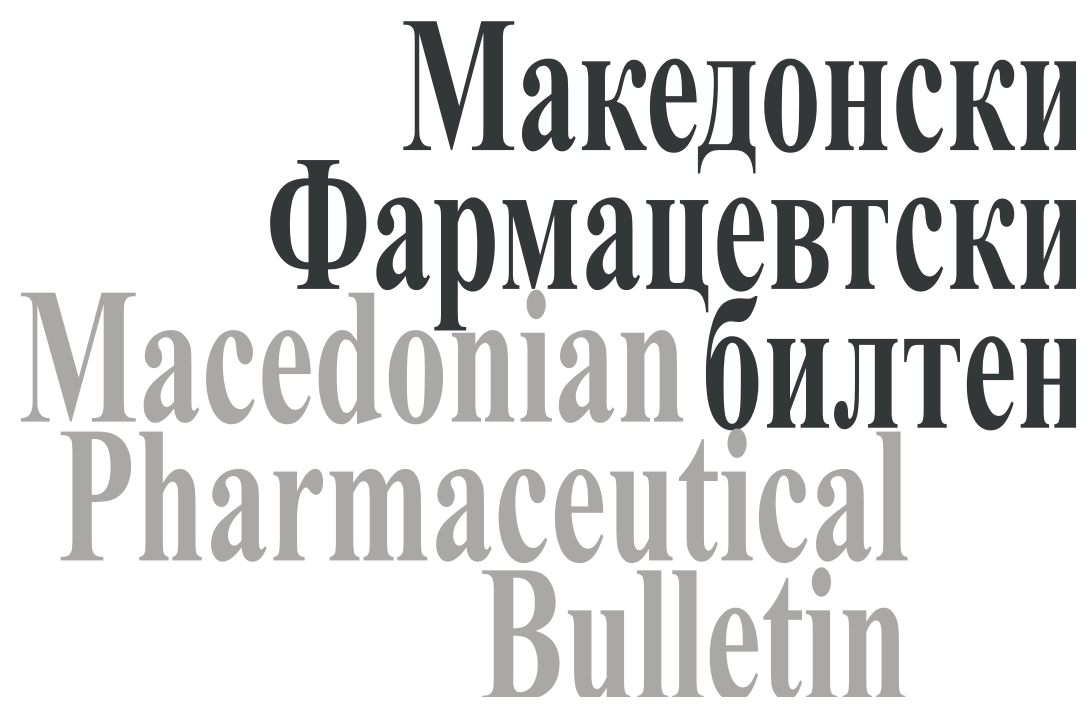

волумен 59 (1, 2) 2013 / volume 59 (1, 2) 2013

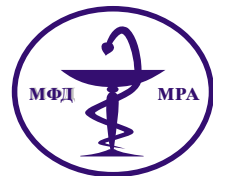

Македонско фармацевтско друштво, ул. Маршал Тито 13б/8, Скопје, Македонија Macedonian Pharmaceutical Association, Marshal Tito 13b/8, Skopje Macedonia 


\title{
Natural antioxidants in cancer prevention
}

\author{
Zorica Arsova-Sarafinovska ${ }^{1}$, Aleksandar J. Dimovski² \\ ${ }^{1}$ Institute of Public Health of the Republic of Macedonia, Department for Quality Control of Medicine, 50 Divizija 6, 1000 \\ Skopje, Republic of Macedonia \\ ${ }^{2}$ Faculty of Pharmacy, Institute of Pharmaceutical Chemistry, Department of Molecular Biology and Genetics, Skopje, \\ Vodnjanska 17, 1000 Skopje, Republic of Macedonia
}

Received: February 2013; Accepted: May 2013

\begin{abstract}
It is well known that oxidative stress is an inevitable event in aerobic life. When our cells use oxygen to create energy, a variety of reactive oxygen (ROS) and nitrogen species (RNS) are generated. These species could attack DNA directly and form mutagenic lesions afterwards. According to the oxidative stress hypothesis of aging, the oxidative damage to critical molecules accumulates over the life period and could ultimately impair the body's function. Moreover, severe oxidative stress causes mutations of tumor suppressor genes, known as one of the initial events in carcinogenesis. Furthermore, it could also play a crucial role in the promotion of the multi-step carcinogenesis. On the other hand, the human body possesses a number of mechanisms that counteract oxidative stress by producing antioxidants in situ, or externally supplied them through foods and/or supplements. Indeed, a considerable amount of laboratory evidence from chemical, cell culture, and animal studies indicates that antioxidants may slow down or possibly prevent the cancer development. Yet, the information from recent cohort, case-control and/or ecological studies is less clear. Therefore, the objectives of this review are to compile a compendium of studies, and to identify effective and promising natural antioxidant interventions.
\end{abstract}

Key words: oxidative stress; reactive oxygen species; reactive nitrogen species; natural antioxidants; cancer;

\section{Introduction}

It is well known that oxidative stress is an inevitable event in aerobic life. When our cells use oxygen to create energy, a variety of reactive oxygen (ROS) and nitrogen species (RNS) are generated as a consequence of ATP (adenosine triphosphate) production by the mitochondria (Bahorun et al., 2006; Halliwell and Gutteridge, 2007). These reactive species could damage the cell structures, including lipids and membranes, proteins and nucleic acids. Their destructive effects are balanced by the antioxidant action of non-enzymatic antioxidants and antioxidant en-

* Tel.: 0038923125044 ext. 106

Fax: 003892 3223-354;

E-mail: zarsova2002@yahoo.co.uk zymes (Halliwell, 1996). Despite the presence of the cell's defense system, oxidative damage accumulates during the life period. Moreover, this radical-related damage to DNA, to proteins and to lipids could play a crucial role in the development of age-dependent diseases such as cancer, arteriosclerosis, arthritis, neurodegenerative disorders and other conditions (Halliwell and Gutteridge, 2007; Pham-Huy, 2008). According to the oxidative stress hypothesis of aging, the oxidative damage to critical molecules accumulates over the life period and could ultimately impair the body's function. Moreover, severe oxidative stress causes DNA damage and mutations of tumor suppressor genes, known as one of the initial events in carcinogenesis (Chatterjee et al., 2007; Valko et al., 2006; Valko et al., 2007). 
The human body possesses a number of mechanisms that counteract oxidative stress by producing antioxidants. They are either produced in situ, or externally supplied through foods and/or supplements. The roles of antioxidants are to act as "free radical scavengers" - to prevent and/or repair damages caused by ROS and RNS, and ultimately to lower the cancer risk (Chatterjee et al., 2007; Valko et al., 2006; Valko et al., 2007; Raj et al., 2011).

Endogenous compounds in cells can be classified as enzymatic and non-enzymatic antioxidants. The most important antioxidant enzymes directly involved in the scavenging of reactive species are: superoxide dismutase (CuZn-SOD, EC 1.15.1.1), catalase (CAT, EC 1.11.1.6), and glutathione peroxidase (GPX, EC 1.11.1.9) (Kenneth, 2003). CuZn-SOD is the first line of defense against free radicals, that catalyzes the dismutation of superoxide anion $\left(\mathrm{O}_{2}{ }^{-}\right)$into hydrogen peroxide $\left(\mathrm{H}_{2} \mathrm{O}_{2}\right)$. The last further transforms into water and oxygen $\left(\mathrm{O}_{2}\right)$ by another enzymes such as catalase (CAT) or glutathione peroxidase (GPX). The selenoprotein GPX enzyme removes $\mathrm{H}_{2} \mathrm{O}_{2}$ and uses it to oxidize reduced form of glutathione $(\mathrm{GSH})$ into oxidized glutathione (GSSG). Besides $\mathrm{H}_{2} \mathrm{O}_{2}$, GPX also reduces lipid or non-lipid hydroperoxides while oxidizing glutathione (GSH) (Bahorun et al., 2006; Droge, 2002; Genestra, 2007; Halliwell, 2007; Pacher et al., 2007; Willcox et al., 2004; Young and Woodside, 2001).

The non-enzymatic antioxidants are divided into metabolic and nutrient antioxidants. Metabolic antioxidants, such as lipoid acid, glutathione, L-ariginine, coenzyme Q10, melatonin, uric acid, bilirubin, metal-chelating proteins, transferrin, etc., are produced by body metabolism (Droge, 2002; Willcox et al., 2004). On the contrary, nutrient antioxidants, such as vitamin E, vitamin C, carotenoids, trace metals (selenium, manganese, zinc), flavonoids, omega-3 and omega-6 fatty acids, must be externally supplied through foods and/or supplements.

Dietary antioxidants play a key role in helping endogenous compounds to combat oxidative stress. They minimize the deleterious effects of free radicals and fight off tumors (Willcox et al., 2004; Donaldson, 2004; Hercberg et al., 2010; Riso et al., 2010; Myung et al, 2011). Vegetables, fruits, legumes, nuts, and seeds are sources of a variety of those bioactive compounds, such as carotenoids (including beta-carotene and lycopene), vitamin $\mathrm{C}$, vitamin $\mathrm{E}$, quercetin, and selenium. Experimental evidence indicates a strong connection between oxidative damage, cancer, and aging. Epidemiological observations suggest that a diet rich in fruits and vegetables is associated with lower incidence of some cancers and longer life expectancy; since fruits and vegetables contain natural antioxidants, a considerable effort has been dedicated to understanding their effects in experimental studies and in human trials (Dolara et al., 2012; Somannavar and Kodliwadmath, 2012).

Most cases of cancer (80-90\%) are linked to environmental causes, and of these, $30-40 \%$ of cancers are linked to the diet. It is believed that most cancers could be prevented by following the recommendations of the 2007 World Cancer Research Fund/American Institute for Cancer Research (WCRF/AICR) Diet and Cancer Report, by not smoking, and by avoiding other types of exposure to tobacco as well as by following recommendations on the subject of diet, physical activity, and weight. (http://www. aicr.org/research/research_science_expert_report.html). Although many dietary recommendations have been proposed to lower the risk of cancer up to date, only few have significant supporting scientific evidence. Therefore, the objectives of this review are to compile a compendium of studies, and to identify effective and promising natural antioxidant interventions.

\section{Natural antioxidants and lung cancer}

\section{Vegetables and lung cancer}

According to the Second Diet and Cancer Report of the World Cancer Research Fund/American Institute for Cancer Research (WCRF/AICR) there are 17 cohort studies of vegetables consumption and lung cancer risk published up to date. 14 cohort studies showed reduced risk associated with higher levels of vegetable consumption (World Cancer Research Fund / American Institute for Cancer Research, DC: AICR, 2007). Out of 27 case-control studies of total vegetables consumption and risk of lung cancer, 17 showed reduced risk associated with higher levels of con-

Table 1. Vegetables and lung cancer

\begin{tabular}{lcccc}
\hline \multirow{2}{*}{ Type of food studied } & \multicolumn{2}{c}{ Cohort Studies } & \multicolumn{2}{c}{ Case-Control Studies } \\
& Reduced Risk* & Total** & Reduced Risk* & Total** \\
\hline Total vegetables & 14 & 17 & 17 & 27 \\
Non-starchy vegetables & 3 & 3 & $n / a$ & $n / a$ \\
Green-leafy vegetables & 5 & 5 & 12 & 17 \\
Carrots & 6 & 6 & 20 & 21 \\
\hline
\end{tabular}

*Number of the studies that reported reduced cancer risk with higher levels of consumption

**Total number of studies

$\mathrm{n} / \mathrm{a}$ : data not available 
sumption (World Cancer Research Fund / American Institute for Cancer Research., Washington, DC: AICR, 2007).

Three cohort studies investigated the association between non-starchy vegetables consumption and lung cancer risk and reported non-significant reduced risk when comparing highest and lowest vegetable intakes (Jansen et al., 2001; Knekt et al., 1997; Kvale et al., 1983). Nonstarchy vegetables are a good source of cancer-preventive substances (such as carotenoids and vitamin C, flavonoids, allylsulphides, and phytoestrogens). Few possible mechanisms of action are proposed: via their antioxidant activities, induction of detoxification enzymes, stimulation of the immunity, antiproliferative potential, and/or modulation of hormone metabolism.

Five cohort studies of green, leafy vegetables intake and risk of lung cancer reported reduced risk when comparing high to low intake groups (Stahelin et al., 1991; Steinmetz et al., 1993).

All six cohort studies of the association between carrots consumption and risk of lung cancer published up to date reported reduced risk (Speizer et al., 1999). Twenty out of the 21 case-control studies showed decreased risk when comparing high against low carrots intake groups.

Carrots contain high levels of carotenoids, mostly alpha-carotene and beta-carotene, as well as other vitamins with protective effects. Tomatoes are a source of vitamin $\mathrm{C}$ and carotenoids, mainly lycopene. Suggested mechanisms of action of carotenoids include the antioxidant properties and ligand-dependent signaling via retinoid receptors (Shardell et al., 2011).

\section{Fruits and lung cancer}

According to the Second Diet and Cancer Report of the World Cancer Research Fund/American Institute for Cancer Research (WCRF/AICR) there is convincing evidence that fruits consumption protect against lung cancer. Pooled analysis from 8 cohort studies of fruits intake and lung cancer showed a statistically significant reduced risk for the highest intake group when compared to the lowest. Similar results were obtained from the 21 case-control studies published up to date. Of the seven ecological studies, four reported non-significant decreased risk in areas of higher fruit consumption, one reported no consistent association, and two reported non-significant increased risk.

A few possible mechanisms are proposed to explain the antioxidant properties of fruits. Fruits, in particular cit- rus fruits, are main sources of vitamin $\mathrm{C}$ and flavonoids. Vitamin C traps ROS and RNS, protecting against freeradical damage. It also regenerates other antioxidants such as vitamin E (Miller, 2002; Padayatty et al., 2003). Some fruits (for instance apples and grapefruit) contain high levels of beta-carotene and other carotenoids, or quercetin and other flavonoids. They can further inhibit carcinogen-activating enzymes and reduce oxidative damage generated by inflammation. Furthermore, Liu et al. (2005) reported that apples given in physiological quantities inhibited carcinogen-induced mammary cancer in rodents.

\section{Dietary quercetin and lung cancer}

According to the WCRF/AICR Diet and Cancer Report there is limited evidence suggesting that dietary quercetin protects against lung cancer. In fact, there are only two cohort studies that investigated foods containing quercetin consumption and lung cancer risk and they showed significant decreased risk for the highest intake groups when compared to the lowest (Hirvonen et al., 2001; Knekt et al., 2002). Two case-control studies showed decreased risk for the highest intake groups when compared to the lowest (statistically significant in one), while one study reported non-significant increased risk (World Cancer Research Fund / American Institute for Cancer Research. Washington, DC: AICR, 2007).

The proposed mechanism of action is that quercetin inhibits expression of cytochrome P450 enzyme CYP1A1 that consequently results in reduced formation of DNA adducts. Indeed, elevated CYP1A1 activity has been linked with increased risk of lung cancer, predominantly in smokers. The protective association of flavonoids is related with specific CYP1A1 genotypes; the fact that explains heterogeneity of the results (Kang et al., 1999; Le Marchand et al., 2000).

\section{Dietary carotenoids and lung cancer}

There is a substantial amount of evidence available from both cohort and case-control studies that food containing carotenoids probably protect against lung cancer. All 11 cohort studies showed decreased risk for the highest intake group, which was statistically significant in three. Twelve of the case-control studies showed decreased risk for the highest intake group when compared to the lowest, which was statistically significant in seven. Three stud-

Table 2. Fruits and lung cancer

\begin{tabular}{|c|c|c|c|c|c|c|}
\hline \multirow{2}{*}{$\begin{array}{c}\text { Type of food } \\
\text { studied }\end{array}$} & \multicolumn{2}{|c|}{ Cohort Studies } & \multicolumn{2}{|c|}{ Case-Control Studies } & \multicolumn{2}{|c|}{ Ecological Studies } \\
\hline & Reduced Risk* & Total $* *$ & Reduced Risk* & Total** & Reduced Risk* & Total $* *$ \\
\hline Fruits & 8 & 8 & 21 & 21 & 4 & 7 \\
\hline
\end{tabular}

Макед. фарм. билт., 59 (1, 2) 3 - 14 (2013) 
Table 3. Dietary quercetin, carotenoids, beta-cryptoxanthin and selenium and lung cancer

\begin{tabular}{lcccc}
\hline \hline \multirow{2}{*}{ Foods containing } & \multicolumn{2}{c}{ Cohort Studies } & \multicolumn{2}{c}{ Case-Control Studies } \\
& Reduced Risk* & Total** & Reduced Risk* & Total** \\
\hline Quercetin & 2 & 2 & 2 & 3 \\
Carotenoids & 11 & 11 & 12 & 16 \\
Beta-cryptoxanthin & 7 & 7 & 0 & 1 \\
Selenium & 0 & 1 & 0 & 2 \\
\hline
\end{tabular}

*Number of the studies that reported reduced cancer risk with higher levels of consumption

**Total number of studies

ies reported increased risk, statistically significant in one, while one study reported no effect on risk (World Cancer Research Fund / American Institute for Cancer Research. DC: AICR, 2007). The similar results were obtained from the studies of serum or plasma levels of carotenoids and risk of lung cancer - four cohort studies and five case-control studies reported decreased risk for the highest serum or plasma levels when compared to the lowest.

Pooled analysis from 7 cohort studies of dietary betacryptoxanthin consumption and lung cancer risk showed a statistically significant decreased risk when comparing high against low intake groups (Mannisto et al., 2004). On the contrary, the single ecological study reported association between increased intake and increased risk (Le Marchand et al., 1995).

Interestingly, data on beta-carotene supplements provide considerable evidence that high-dose supplements have a contrasting effect, at least in smokers, increasing the risk of lung cancer. Data on dietary beta-carotene (15 cohort studies, a pooled analysis, 32 case-control studies, 2 ecological studies) and serum or plasma beta-carotene (13 cohort studies, 16 case-control studies, 1 ecological study) showed no consistent evidence for association (Lin et al., 2009; Druesne-Pecollo et al., 2010; Jeon et al., 2011).

\section{Dietary selenium and lung cancer}

According to the WCRF/AICR Diet and Cancer Report there is limited evidence to suggest that seleniumrich foods protect against lung cancer. One cohort study showed non-significant increased risk in non-smokers and non-significant decreased risk in smokers for the highest intake group comparing to the lowest (Schrauzer et al., 1977). Both case-control studies showed a non-significant increased risk for the highest intake group (Cheng et al., 1996; Hu et al., 1997). Similar results were obtained in the studies of plasma or serum selenium and lung cancer - seven cohort studies showed decreased risk for the highest selenium levels, but statistical significance was reached in only two of them (Knekt et al., 1998; Salonen et al., 1985). Six case-control studies showed decreased risk for the highest levels when compared to the lowest. One study investigated plasma or serum selenium demonstrated non-sig- nificant increased risk (Tominaga et al., 1992). Two cohort studies that investigated selenium levels in nails showed decreased risk for the highest selenium levels when compared to the lowest, statistically significant in one (van den Brandt et al., 1993; Fritz et al., 2011).

\section{Natural antioxidants and colorectal cancer}

\section{Vegetables and colorectal cancer}

A substantial amount of evidence is available that nonstarchy vegetables protect against colorectal cancer but the findings are inconsistent (Papaioannou et al., 2011). 17 cohort studies of non-starchy vegetables consumption and risk of colorectal cancer reported comparable risk between the highest and lowest intake groups, while 11 were in the direction of reduced risk (World Cancer Research Fund / American Institute for Cancer Research. Washington, DC: AICR, 2007).

Additionally, there is consistent evidence, mostly from case-control studies, that garlic consumption protects against colorectal cancer in a dose-response manner. Indeed, all six case-control studies showed decreased risk for the highest consumers of garlic, statistically significant in three (Levi et al., 1999; Yang et al., 1994). Additionally, the data obtained from the study with model carcinogens and transplantable tumors were in favor of the anticancer effect of garlic and some of its allyl sulphur components. Furthermore, the findings from studies with animal models demonstrated that allyl sulphides effectively inhibit tumor formation in the colon (Chu et al., 2007).

\section{Fruits and colorectal cancer}

There are a number of researchers that studied the association between the fruit consumption and colorectal cancer, but the evidence obtained is inconsistent. Twenty cohort studies and 57 case-control studies investigated fruits and colorectal cancer. Thirteen cohort studies showed decreased risk with increased intake, but the statistical significance was reached only in two studies (World Cancer Research Fund / American Institute for Cancer Research. Washington, DC: AICR, 2007). 
Table 4. Natural antioxidants and colorectal cancer

\begin{tabular}{lcccc}
\hline \hline \multirow{2}{*}{ Foods/ } & \multicolumn{2}{c}{ Cohort Studies } & \multicolumn{2}{c}{ Case-Control Studies } \\
Foods containing & Reduced Risk & Total** & Reduced Risk* & Total** \\
\hline Non-starchy vegetables & 11 & 17 & $\mathrm{n} / \mathrm{a}$ & $\mathrm{n} / \mathrm{a}$ \\
Garlic & $\mathrm{n} / \mathrm{a}$ & $\mathrm{n} / \mathrm{a}$ & 6 & 6 \\
Fruits & 13 & 20 & 30 & 57 \\
Selenium & $\mathrm{n} / \mathrm{a}$ & $\mathrm{n} / \mathrm{a}$ & 15 & 15 \\
\hline
\end{tabular}

*Number of the studies that reported reduced cancer risk with higher levels of consumption

**Total number of studies

$\mathrm{n} / \mathrm{a}$ : data not available

\section{Dietary selenium and colorectal cancer}

A substantial amount of data on the association between dietary selenium and colorectal cancer (although from case-control studies only) suggested that seleniumrich foods protect against colorectal cancer. Fifteen casecontrol studies reported decreased risk, statistically significant in four (World Cancer Research Fund / American Institute for Cancer Research., Washington, DC: AICR, 2007).

The proposed mechanism of action is that selenium deficiency causes a lack of selenoprotein expression. There are twenty-five selenoproteins identified up to date; all of them having significant anti-inflammatory and antioxidant functions. For example, four selenoproteins belong to glutathione peroxidases family; they protect lipids, lipoproteins, and DNA from oxidative damage. Three selenoproteins are thioredoxin reductases which regenerate oxidized ascorbic acid to its active form. All of them are known to be rapidly degraded during selenium deficiency. Moreover, it was suggested that supraphysiological amounts of selenium could affect programmed cell death, DNA repair, carcinogen metabolism, immune system, and anti-angiogenic effects (Ganther, 1999; Higdon, et al., 2007).

\section{Natural antioxidants and prostate cancer}

\section{Tomatoes, dietary lycopene and prostate cancer}

Lycopene is the most efficient antioxidant among all carotenoids identified up to date. It is most bioavailable from cooked and pureed tomatoes. Therefore, the best way of measuring the systemic exposure is study on tomato sauce, or on serum or plasma lycopene.

There is a substantial amount of consistent evidence, from both cohort and case-control studies that lycopenecontaining foods protect against prostate cancer (Seren et al., 2008; Vance et al., 2013).

Three of the cohort studies of tomatoes consumption and risk of prostate cancer showed decreased risk for the highest intake groups when compared to the lowest (Platz et al., 2004). Seven of the case-control studies reported decreased risk for the highest intake groups when compared to the lowest. Two cohort studies of dietary lycopene consumption and prostate cancer reported non-significant decreased risk for the highest intake groups when compared to the lowest, while the other study showed non-significant increased risk. Nine case-control studies showed decreased risk for the highest intake groups when compared to the lowest, which was statistically significant in one.

Five cohort studies of serum or plasma lycopene and prostate cancer risk reported a non-significant reduced risk for the highest intake groups when compared to the lowest; the other study showed an increased risk (Gann et al., 1999). Both case-control studies of serum or plasma lycopene showed a statistically significant reduced risk for the highest intake groups (Lu et al., 2001; Dahan et al., 2008).

\section{Dietary beta-carotene and prostate cancer}

In accordance with the evidence from cohort and casecontrol studies it could be concluded that foods containing beta-carotene does not have a substantial effect on the risk of prostate cancer.

Three cohort studies of dietary beta-carotene consumption and prostate cancer showed non-significant increased risk with increased intake, while three studies showed no effect on risk. Although fourteen case-control studies reported decreased risk with increased intake, statistical significance was reached only in two relatively low quality studies. The similar findings were obtained from the cohort and case-control studies of serum or plasma beta-carotene and prostate cancer risk (Vogt et al., 2002).

\section{Dietary vitamin E and prostate cancer}

It is well known that vitamin E slows down DNA damage, increases DNA repair, reduces lipid peroxidation, and prevents activation of some carcinogens. Additionally, it protects body's vitamin A and selenium. While acting as a free-radical scavenger, it enhances the immune response in the body, which may play a crucial role in cancer defenses (Willis and Wians, 2003). Vitamin E has also been shown to delay the growth of human prostate tumors induced in animal models (Fleshner et al., 1999). 
Table 5. Natural antioxidants and prostate cancer

\begin{tabular}{lcccccc}
\hline \hline \multirow{2}{*}{$\begin{array}{l}\text { Type of food stud- } \\
\text { ied }\end{array}$} & \multicolumn{2}{c}{ Cohort Studies } & \multicolumn{2}{c}{ Case-Control Studies } & \multicolumn{2}{c}{ Ecological Studies } \\
Reduced Risk & Total** & Reduced Risk & Total** & Reduced Risk* & Total** \\
\hline Tomatoes & 3 & 5 & 7 & 9 & $\mathrm{n} / \mathrm{a}$ & $\mathrm{n} / \mathrm{a}$ \\
Lycopene & 2 & 2 & 9 & 14 & $\mathrm{n} / \mathrm{a}$ & $\mathrm{n} / \mathrm{a}$ \\
Beta-carotene & 4 & 10 & 14 & 21 & $\mathrm{n} / \mathrm{a}$ & $\mathrm{n} / \mathrm{a}$ \\
Vitamin E & 1 & 7 & $\mathrm{n} / \mathrm{a} / \mathrm{a}$ & $\mathrm{n} / \mathrm{a}$ \\
Selenium & 1 & 1 & 2 & 7 & 2 & 2 \\
\hline
\end{tabular}

*Number of the studies that reported reduced cancer risk with higher levels of consumption

**Total number of studies

$\mathrm{n} / \mathrm{a}$ : data not available

However, there is limited evidence that vitamin E- rich foods protect against prostate cancer. Indeed, the evidence, obtained mostly from case-control studies, was inconsistent. For example, statistical significant decreased risk for the highest intake groups was demonstrated only in one out of seven cohort studies of serum or plasma alpha-tocopherol and prostate cancer (Goodman et al., 2003). Most studies of dietary vitamin E consumption and prostate cancer risk showed non-significant decreased risk, although there is heterogeneity in the direction of effect reported and effect estimates are usually very close to 1 (no effect). All six cohort studies that investigated serum gamma-tocopherol and prostate cancer reported inverse association (Weinstein et al., 2005; Lin et al., 2009; Klein et al., 2011).

\section{Dietary selenium and prostate cancer}

According to the $2007 \mathrm{WCRF} / \mathrm{AICR}$ Diet and Cancer Report there is a considerable amount of evidence from both cohort and case-control studies, that selenium-rich foods protect against prostate cancer. Eight cohort studies and four case-control studies reported inverse associations between serum or plasma selenium and prostate cancer $(\mathrm{Li}$ et al., 2004). Two cohort studies of selenium levels in nails and prostate cancer risk demonstrated non-significant decreased risk for the highest intake groups. Two cohort studies investigated selenium levels in nails for advanced or aggressive prostate cancer. Both showed statistically significant decreased risk for the highest intake groups (van den Brandt et al., 2003; Klein et al., 2011).

\section{Natural antioxidants and breast cancer}

\section{Fruits, vegetables and breast cancer}

Some epidemiologic studies suggest that fruit and vegetable consumption could reduce risk of breast cancer. However, most have been case-control studies in which selection bias may strongly influence the results. In 2000, a meta-analysis was performed, aimed to summarize exist- ing data on the relationship between breast cancer, fruit and vegetable consumption and/or the intake of beta-carotene and vitamin C. Relative risks were extracted from 26 studies published in the period from 1982 to 1997 . It confirms the association between intake of vegetables and, to a lesser extent, fruits and breast cancer risk from published sources (Gandini et al., 2000).

Smith-Warner et al. (2001) studied the relation between breast cancer and total and specific fruit and vegetable group intakes by means of standardized exposure definitions. No associations were found for green leafy vegetables, 8 botanical groups, and 17 specific fruits and vegetables. Therefore, the results suggest that fruit and vegetable consumption during adulthood is not significantly associated with reduced breast cancer risk (Smith-Warner et al., 2001).

Riboli and Norat (2003) wanted to summarize evidence from case-control and prospective studies on fruit and vegetable consumption and cancer risk with a meta-analytic approach. According to their findings, breast cancer is associated with vegetables, but not with fruits consumption (Riboli and Norat, 2003).

Furthermore, of the results from the European Prospective Investigation into Cancer and Nutrition (EPIC) study (the largest study of nutrition and health ever undertaken, with over half a million people from ten European countries enrolled) confirmed that the consumption of fruit and vegetables is not associated with breast cancer risk. This critical finding helped to narrow down the factors involved in breast cancer etiology and prevention (http://epic.iarc.fr/ research/cancer.php).

\section{Natural antioxidants and stomach cancer}

\section{Vegetables and stomach cancer}

There are a number of researchers that studied the possible association between the vegetables consumption and stomach cancer. On the basis of a substantial amount of evidence available, including on specific subtypes, particu- 
larly green yellow vegetables, the 2007 WCRF/AICR Diet and Cancer Report sums up that vegetables probably protect against stomach cancer in a dose-response manner. Of 45 case-control studies that studied non-starchy vegetable consumption and stomach cancer, 28 reported statistically significant decreased risk. Additionally, the majority of the 17 remaining studies that reported no significant effect on risk were in the direction of decreased risk (Gajalakshmi and Shanta, 1996).

Results from ecological studies on non-starchy vegetable consumption were inconclusive, with almost as many studies reporting increased risk as reported decreased risk (Engel et al., 2003).

Of the 21 case-control studies on green yellow vegetable consumption and stomach cancer incidence, 16 showed decreased risk. This exposure included green-yellow vegetables, green vegetables, yellow vegetables, yellow-orange vegetables, carrots and pumpkins, and high-carotenoid vegetables (Zickute et al., 2005). Nine case-control studies that investigated green, leafy vegetables consumption and stomach cancer showed decreased risk with increased intake (Zickute et al., 2005).

Significant inverse association was found in seven out of 12 case-control studies reporting decreased risk with increased intake of lettuce or salad leaves (Ito et al., 2003).

Two cohort studies on tomatoes consumption and stomach cancer demonstrated a non-significant increased risk with increased intake, while most case-control studies showed decreased risk with increased intake (Tokui et al., 2005).

One of the proposed mechanisms of action is that bioactive constituents could protect against H.pylori-induced damage, particularly inflammation, the crucial event in the development of stomach cancers. It is well known that al- lium vegetables, especially garlic, are high in flavonols and organosulphur compounds. They have antibiotic properties. Although this may act directly against $H$ pylori, a study in humans has not proven this effect. The possible mechanism of action is that antibacterial effects of garlic might inhibit the colonization of the stomach after $H$ pylo$r i$-induced atrophy. Indeed, a study with animals provided evidence that dietary garlic can reduce the severity of $H p y$ lori-associated gastritis (Iimuro et al., 2002).

According to the findings, allium vegetables-rich diet most likely protects against stomach cancer. The data from two ecological studies suggested significant decreased incidence of stomach cancer with increased consumption of allium vegetables. Similar results were obtained in case controls studies that showed reduced risk when comparing high with low intake groups (Takezaki et al., 1999).

\section{Fruits and stomach cancer}

On the basis on the substantial amount of evidence on association between fruits intake and stomach cancer risk, the 2007 WCRF/AICR Diet and Cancer Report summarized that fruits probably protect against stomach cancer in a dose-response manner. Forty case-control studies demonstrated decreased risk for the highest intake groups when compared to the lowest, being statistically significant in 25 (López-Carrillo et al., 2004).

\section{Dietary selenium and stomach cancer}

There is a substantial amount on the association between dietary selenium consumption and stomach cancer incidence, mostly from case-control studies. However there is no strong evidence that selenium-rich foods protect

Table 6. Natural antioxidants and stomach cancer

\begin{tabular}{|c|c|c|c|c|c|c|}
\hline \multirow{2}{*}{$\begin{array}{l}\text { Type of food } \\
\text { studied }\end{array}$} & \multicolumn{2}{|c|}{ Cohort Studies } & \multicolumn{2}{|c|}{ Case-Control Studies } & \multicolumn{2}{|c|}{ Ecological Studies } \\
\hline & Reduced Risk* & Total $* *$ & Reduced Risk* & Total** & Reduced Risk* & Total** \\
\hline Vegetables & $n / a$ & $n / a$ & 27 & 45 & $n / a$ & $n / a$ \\
\hline $\begin{array}{l}\text { Non-starchy } \\
\text { vegaables }\end{array}$ & $n / a$ & $n / a$ & 16 & 21 & $n / a$ & $n / a$ \\
\hline $\begin{array}{l}\text { Green, leafy } \\
\text { vegetables }\end{array}$ & $n / a$ & $n / a$ & 9 & 12 & $n / a$ & $n / a$ \\
\hline Letuce & $n / a$ & $n / a$ & 7 & 12 & $n / a$ & $n / a$ \\
\hline Tomato & 2 & 2 & $n / a$ & $n / a$ & $n / a$ & $n / a$ \\
\hline Allium & $n / a$ & $n / a$ & $n / a$ & $n / a$ & 2 & 2 \\
\hline Fruits & $n / a$ & $n / a$ & 30 & 40 & $n / a$ & $n / a$ \\
\hline Selenium & $n / a$ & $n / a$ & 0 & 1 & 2 & 2 \\
\hline
\end{tabular}

*Number of the studies that reported reduced cancer risk with higher levels of consumption

**Total number of studies

n/a: data not available 
against stomach cancer onset (Table 6).

The single case-control study that investigated dietary selenium consumption and stomach cancer reported that dietary selenium was not significantly associated with stomach cancer risk, while most ecological studies showed that low selenium levels were associated with increased stomach cancer risk (World Cancer Research Fund / American Institute for Cancer Research. Food, Washington, DC: AICR, 2007).

\section{Conclusion}

The implication of oxidative stress in the promotion of carcinogenesis suggests that antioxidant therapy represents a promising opportunity for cancer prevention. Additionally, a therapeutic strategy to increase the antioxidant capacity of cells may be used to fortify the long term effective treatment. In the past it was generally believed that high-dose dietary supplements can modify the risk of some cancers. Although some studies in specific, usually highrisk, groups have shown evidence of cancer prevention from some supplements, this finding may not apply to the general population. Their level of benefit may be different, and there may be unexpected adverse effects. Therefore it is unwise to recommend widespread supplement use as a means of cancer prevention.

The 2007 World Cancer Research Fund/American Institute for Cancer Research (WCRF/AICR) Diet and Cancer Report strongly recommend that increasing the consumption of the relevant nutrients through the usual diet is preferred and the best source of antioxidants is foods and drinks, not dietary supplements.

\section{References}

Bahorun, T., Soobrattee, M.A., Luximon-Ramma, V. Aruoma, O.I. 2006. Free radicals and antioxidants in cardiovascular health and disease. Internet J. Med. Update 1, 1-17.

Chatterjee, M., Saluja, R., Kanneganti S. 2007. Biochemical and molecular evaluation of neutrophil NOS in spontaneously hypertensive rats. Cell. Mol. Biol. 53, 84-93.

Cheng, T.J., Christiani, D.C., Xu, X., Wain, J.C., Wiencke, J.K., Kelsey, K.T. 1996. Increased micronucleus frequency in lymphocytes from smokers with lung cancer. Mutat. Res. 17, 349(1), 43-50.

Chu, Q., Lee, D.T., Tsao, S.W., Wang, X., Wong, Y.C. 2007. S-allylcysteine, a water-soluble garlic derivative, suppresses the growth of a human androgen-independent prostate cancer xenograft, CWR22R, under in vivo conditions. BJU Int. 99(4), 925-32.

Dahan, K., Fennal, M., Kumar, N.B. 2008. Lycopene in the prevention of prostate cancer. J. Soc. Integr. Oncol. 6, 29-36.

Dolara, P., Bigagli, E., Collins, A. 2012. Antioxidant vitamins and mineral supplementation, life span expansion and cancer incidence: a critical commentary. Eur. J. Nutr. 51(7):769-81. Epub 2012 Jun 9.

Donaldson M.S. 2004. Nutrition and cancer: A review of the evidence for an anti-cancer diet. Nutr. J. 3, 19-25.

Droge W. 2002. Free radicals in the physiological control of cell function. Review. Physiol Rev. 82, 47-95.

Druesne-Pecollo, N., Latino-Martel, P., Norat, T., Barrandon, E., Bertrais, S., Galan, P., Hercberg, S. 2010. Beta-carotene supplementation and cancer risk: a systematic review and meta-analysis of randomized controlled trials. Int. J. Cancer. 127(1),172-184.

Engel, L.S., Chow, W.H., Vaughan, T.L., Gammon, M.D., Risch, H.A., Stanford, J.L., Schoenberg, J.B., Mayne, S.T., Dubrow, R., Rotterdam, H., West, A.B., Blaser, M., Blot, W.J., Gail, M.H., Fraumeni J.F. 2003. Population attributable risks of esophageal and gastric cancers. J. Natl. Cancer. Inst. 17, 95(18), 1404-13.

Fleshner, N., Fair, W.R., Huryk, R., Heston, W.D. 1999. Vitamin $\mathrm{E}$ inhibits the high-fat diet promoted growth of established human prostate LNCaP tumors in nude mice. J. Urol. 161(5), 1651-4.

Fritz, H., Kennedy, D., Fergusson, D., Fernandes, R., Cooley, K., Seely, A., Sagar, S., Wong, R., Seely, D. 2011. Selenium and lung cancer: a systematic review and meta analysis. PLoS One 6(11):e26259

Gajalakshmi, C.K., Shanta, V. 1996. Lifestyle and risk of stomach cancer: a hospital-based case-control study. Int. J. Epidemiol. 25, 1146-53.

Gandini, S., Merzenich, H., Robertson, C., Boyle, P. 2000. Metaanalysis of studies on breast cancer risk and diet: the role of fruit and vegetable consumption and the intake of associated micronutrients. Eur.J. Cancer 36, 636-646.

Ganther, H.E. 1999. Selenium metabolism, selenoproteins and mechanisms of cancer prevention: complexities with thioredoxin reductase. Carcinogenesis 20, 1657-66.

Genestra, M. 2007. Oxyl radicals, redox-sensitive signalling cascades and antioxidants. Review. Cell Signal. 19, 1807-19

Goodman, G.E., Schaffer, S., Omenn, G.S., Chen, C., King, I. 2003. The association between lung and prostate cancer risk, and serum micronutrients: results and lessons learned from beta-carotene and retinol efficacy trial. Cancer Epidemiol. Biomarkers Prev. 12(6), 518-26.

Halliwell, B. 1996. Antioxidants in human health and disease. Ann. Rev. Nutr. 16, 33-50.

Halliwell, B. 2007. Biochemistry of oxidative stress. Biochem. Soc. Trans. 35, 1147-50.

Halliwell, B., Gutteridge, J.M.C. 2007. Free radicals in biology and medicine. 4th ed. Oxford, UK: Clarendon Press.

Hercberg, S., Kesse-Guyot, E., Druesne-Pecollo, N., Touvier, M., Favier, A., Latino-Martel, P., Briançon, S., Galan, P. 2010. Incidence of cancers, ischemic cardiovascular diseases and mortality during 5-year follow-up after stopping antioxidant vitamins and minerals supplements: a post-intervention follow-up in the SU.VI.MAX study. Int. J. Cancer. 127(8), 1875-1881.

Higdon, J., Drake, V.J., Whanger, P.D. 2007. Selenium. Linus Pauling Institute. Oregon State University. Micronutrient Information Center. http://lpi.oregonstate.edu/infocenter/ minerals/selenium/

Hirvonen, T., Virtamo, J., Korhonen, P., Albanes, D., Pietinen, P. 2001. Flavonol and flavone intake and the risk of cancer in male smokers (Finland). Cancer Causes Control 12(9), 78996.

http://epic.iarc.fr/research/cancer.php

Hu, J., Johnson, K.C., Mao, Y., Xu, T., Lin, Q, Wang, C., Zhao, F., Wang, G., Chen, Y., Yang, Y. 1997. A case-control study 
of diet and lung cancer in northeast China. Int. J. Cancer. 11;71(6), 924-31.

Iimuro, M., Shibata, H., Kawamori, T., Matsumoto, T., Arakawa, T., Sugimura, T., Wakabayashi, K. 2002. Suppressive effects of garlic extract on Helicobacter pylori-induced gastritis in Mongolian gerbils. Cancer Lett. 10; 187(1-2), 61-8.

Ito, L.S., Inoue, M., Tajima, K., Yamamura, Y., Kodera, Y., Hirose, K., Takezaki, T., Hamajima, N., Kuroishi, T., Tominaga, S. 2003. Dietary factors and the risk of gastric cancer among Japanese women: a comparison between the differentiated and non-differentiated subtypes. Ann. Epidemiol. 13(1), 2431.

Jansen, M.C., Bueno-de-Mesquita, H.B., Räsänen, L., Fidanza, F., Nissinen, A.M., Menotti, A., Kok, F.J., Kromhout, D. 2001. Cohort analysis of fruit and vegetable consumption and lung cancer mortality in European men. Int $\mathrm{J}$ Cancer. $15,92(6), 913-8$

Jeon, Y.J., Myung, S.K., Lee, E.H., Kim, Y., Chang, Y.J., Ju, W., Cho, H.J., Seo, H.G., Huh, B.Y. 2011. Effects of betacarotene supplements on cancer prevention: meta-analysis of randomized controlled trials. Nutr. Cancer. 63(8), 11961207.

Kang, Z.C., Tsai, S.J., Lee, H. 1999. Quercetin inhibits benzo[a] pyrene-induced DNA adducts in human Hep G2 cells by altering cytochrome P-450 1A1 gene expression. Nutr. Cancer. 35, 175-9.

Kenneth A.C. 2003. Dietary antioxidants during cancer chemotherapy: impact on chemotherapeutic effectiveness and development of side effects. Nutr. Cancer 37, 1-18.

Klein, E.A., Thompson, I.M. Jr., Tangen, C.M., Crowley, J.J., Lucia, M.S., Goodman, P.J., Minasian, L.M., Ford, L.G., Parnes, H.L., Gaziano, J.M., Karp, D.D., Lieber, M.M., Walther, P.J., Klotz, L., Parsons, J.K., Chin, J.L., Darke, A.K., Lippman, S.M., Goodman, G.E., Meyskens, F.L. Jr, Baker, L.H. 2011. Vitamin E and the risk of prostate cancer: the Selenium and Vitamin E Cancer Prevention Trial (SELECT). JAMA 306(14), 1549-1556.

Knekt P, Marniemi J, Teppo L, Heliövaara M, Aromaa A. 1998. Is low selenium status a risk factor for lung cancer? Am J Epidemiol. 148(10), 975-82.

Knekt, P., Järvinen, R., Seppänen, R., Heliövaara, M., Teppo, L., Pukkala, E., Aromaa, A. 1997. Dietary flavonoids and the risk of lung cancer and other malignant neoplasms. Am. J. Epidemiol. 146, 223-30.

Knekt, P., Kumpulainen, J., Järvinen, R., Rissanen, H., Heliövaara, M., Reunanen, A., Hakulinen, T., Aromaa, A. 2002. Flavonoid intake and risk of chronic diseases. Am. J. Clin. Nutr. 76(3), 560-8.

Kvale, G., Bjelke, E., Gart, J.J. 1983. Dietary habits and lung cancer risk. Int. J. Cancer 31, 397-405.

Le Marchand, L., Hankin, J.H., Bach, F., Kolonel, L.N., Wilkens, L.R., Stacewicz-Sapuntzakis, M., Bowen, P.E., Beecher, G.R., Laudon, F., Baque, P., et al. 1995. An ecological study of diet and lung cancer in the South Pacific. Int. J. Cancer. 63(1), 18-23.

Le Marchand, L., Murphy, S.P., Hankin, J.H., Wilkens, L.R., Kolonel, L.N. 2000. Intake of flavonoids and lung cancer. J. Natl. Cancer Inst. 92(2), 154-60.

Levi, F., Pasche, C., La Vecchia, C., Lucchini, F., Franceschi, S. 1999. Food groups and colorectal cancer risk. Br. J. Cancer. 79(7-8), 1283-7.

Li, H., Stampfer, M.J., Giovannucci, E.L., Morris, J.S., Willett, W.C., Gaziano, J.M., Ma, J. 2004. A prospective study of plasma selenium levels and prostate cancer risk. J. Natl. Cancer Inst. 96(9), 696-703.

Lin, J., Cook, N.R., Albert, C., Zaharris, E., Gaziano, J.M., Van Denburgh, M., Buring, J.E., Manson, J.E. 2009. Vitamins C and $\mathrm{E}$ and beta carotene supplementation and cancer risk: a randomized controlled trial. J. Natl. Cancer. Inst. 101(1),1423.

Liu, R.H., Liu, J., Chen, B. 2005. Apples prevent mammary tumors in rats. J. Agric. Food Chem. 53, 2341-3.

López-Carrillo, L., Torres-Lopez, J., Galvan-Portillo, M. 2004. Helicobacter pylori-CagA seropositivity and nitrite and ascorbic acid food intake as predictors for gastric cancer. Eur. J. Cancer 40, 1752-9.

Lu, Q.Y., Hung, J.C., Heber, D., Go, V.L., Reuter, V.E., CordonCardo, C., Scher, H.I., Marshall, J.R., Zhang Z.F. 2001. Inverse associations between plasma lycopene and other carotenoids and prostate cancer. Cancer Epidemiol. Biomarkers Prev. 10(7), 749-56.

Männistö, S., Smith-Warner, S.A., Spiegelman, D., Albanes, D., Anderson, K., van den Brandt, P.A., Cerhan, J.R., Colditz, et al.. 2004. Dietary carotenoids and risk of lung cancer in a pooled analysis of seven cohort studies. Cancer Epidemiol. Biomarkers Prev. 13(1), 40-8.

Miller, A.B. 2002. Vegetables and fruits and lung cancer. IARC Sci Publ 156, 85-7.

Myung, S.K., Ju, W., Kim, S.C. 2011. Korean Meta-analysis (KORMA) Study Group. Vitamin or antioxidant intake (or serum level) and risk of cervical neoplasm: a meta-analysis. BJOG 118(11),1285-1291.

Pacher, P., Beckman, J.S., Liaudet, L. 2007. Nitric oxide and peroxynitrite in health and disease. Physiol. Rev. 87, 315424.

Padayatty, S.J., Katz, A., Wang, Y., Eck, P., Kwon, O., Lee, J.H., Chen, S., Corpe, C., Dutta, A., Dutta, S.K., Levine, M. 2003. Vitamin $\mathrm{C}$ as an antioxidant: evaluation of its role in disease prevention. J. Am. Coll. Nutr. 22, 18-35.

Papaioannou, D., Cooper, K.L., Carroll, C., Hind, D., Squires, H., Tappenden, P., Logan, R.F. 2011. Antioxidants in the chemoprevention of colorectal cancer and colorectal adenomas in the general population: a systematic review and meta-analysis. Colorectal. Dis. 13(10), 1085-1099.

Pham-Huy, L.A., He, H., Pham-Huy, C. 2008. Free Radicals, Antioxidants in Disease and Health. Int.J.Biomed. Sci. 4(2), 89-96.

Platz E.A., De Marzo A.M., Erlinger T.P., Rifai N., Visvanathan K., Hoffman S.C., Helzlsouer K.J. 2004. No association between pre-diagnostic plasma C-reactive protein concentration and subsequent prostate cancer. Prostate. 59, 393-400.

Raj, L., Ide, T., Gurkar, A.U., Foley, M., Schenone, M., Li, X., Tolliday, N.J., Golub, T.R., Carr, S.A., Shamji, A.F., Stern, A.M., Mandinova, A., Schreiber, S.L., Lee, S.W. 2011. Selective killing of cancer cells by a small molecule targeting the stress response to ROS. Nature 475(7355), 231-234.

Riboli, E., Norat, T. 2003. Epidemiologic evidence of the protective effect of fruit and vegetables on cancer risk. Am. J. Clin. Nutr. 78, 559S-569S.

Riso, P., Martini, D., Møller, P., Loft, S., Bonacina, G., Moro, M., Porrini, M. 2010. DNA damage and repair activity after broccoli intake in young healthy smokers. Mutagenesis, 25(6), 295-602.

Salonen, J.T., Salonen, R., Lappetelainen, R., et al. 1985. Risk of cancer in relation to serum concentrations of selenium 
and vitamins A and E: matched case-control analysis of prospective data. BMJ 290, 417-20.

Schrauzer, G.N., White, D.A., Schneider, C.J. 1977. Cancer mortality correlation studies - III: statistical associations with dietary selenium intakes. Bioinorg. Chem. 7, 23-31.

Seren, S., Lieberman, R., Bayraktar, U.D., Heath, E., Sahin, K., Andic, F., Kucuk, O. 2008. Lycopene in cancer prevention and treatment. Am. J. Ther. 15(1), 66-81.

Shardell, M.D., Alley, D.E., Hicks, G.E., El-Kamary, S.S, Miller, R.R., Semba, R.D., Ferrucci, L. 2011. Low-serum carotenoid concentrations and carotenoid interactions predict mortality in US adults: the Third National Health and Nutrition Examination Survey. Nutr. Res. 31(3), 178-189.

Smith-Warner, S.A., Spiegelman, D., Yaun, S.S., Adami, H.O., Beeson, W.L., van den Brandt, P.A., Folsom, A.R., et al. 2001. Intake of fruits and vegetables and risk of breast cancer: a pooled analysis of cohort studies. JAMA. 285(6), 769-76.

Somannavar, M.S., Kodliwadmath, M.V. 2012. Correlation between oxidative stress and antioxidant defence in South Indian urban vegetarians and non-vegetarians. Eur. Rev. Med. Pharmacol. Sci. 16(3), 351-354.

Speizer, F.E., Colditz, G.A., Hunter, D.J., Rosner, B., Hennekens, C. 1999. Prospective study of smoking, antioxidant intake, and lung cancer in middle-aged women (USA). Cancer Causes Control. 10(5), 475-82.

Stähelin, H.B., Gey, K.F., Eichholzer, M., Lüdin, E., Bernasconi, F., Thurneysen, J., Brubacher G. 1991. Plasma antioxidant vitamins and subsequent cancer mortality in the 12-year follow-up of the prospective Basel Study. Am. J. Epidemiol. 133, 766-75.

Steinmetz, K.A., Potter, J.D., Folsom, A.R. 1993. Vegetables, fruit, and lung cancer in the Iowa Women's Health Study. Cancer Res. 53, 536-43.

Takezaki, T., Gao, C.M., Ding, J.H., Liu, T.K., Li, M.S., Tajima, K. 1999. Comparative study of lifestyles of residents in high and low risk areas for gastric cancer in Jiangsu Province, China; with special reference to allium vegetables. J Epidemiol. 9(5), 297-305.

Tokui, N., Yoshimura, T., Fujino, Y., Mizoue, T., Hoshiyama, Y., Yatsuya, H., Sakata, K., Kondo, T., Kikuchi, S., Toyoshima, H., Hayakawa, N., Kubo, T., Tamakoshi A., JACC Study Group. 2005. Dietary habits and stomach cancer risk in the JACC Study. J. Epidemiol. 15, S98-108.

Tominaga, K., Saito, Y., Mori, K., Miyazawa, N., Yokoi, K., Koyama, Y., Shimamura, K., Imura, J., Nagai, M. 1992. An evaluation of serum microelement concentrations in lung cancer and matched non-cancer patients to determine the risk of developing lung cancer: a preliminary study. Jpn. J. Clin. Oncol. 22, 96-101.

Valko, M., Leibfritz, D., Moncol, J., Cronin, M.T., Mazur, M., Telser, J. 2007. Free radicals and antioxidants in normal physiological functions and human disease. Int. J. Biochem. Cell Biol. 39, 44-84.

Valko, M., Rhodes, C.J., Moncol, J., Izakovic, M., Mazur, M. 2006. Free radicals, metals and antioxidants in oxidative stress-induced cancer. Chem Biol Interact. 160(1), 1-40.

van den Brandt, P.A., Goldbohm, R.A., van 't Veer, P., Bode, P., Dorant, E., Hermus, R.J., Sturmans, F. 1993. A prospective cohort study on selenium status and the risk of lung cancer. Cancer Res. 53, 4860-5.

van den Brandt, P.A., Zeegers, M.P., Bode, P., Goldbohm, R.A. 2003. Toenail selenium levels and the subsequent risk of prostate cancer: a prospective cohort study. Cancer Epidemiol Biomarkers Prev. 12, 866-71.

van Gils, C.H., Peeters, P.H., Bueno-de-Mesquita, H.B., Boshuizen, H.C., Lahmann, P.H., Clavel-Chapelon, F., Thiébaut, A., et al. 2005. Consumption of vegetables and fruits and risk of breast cancer. JAMA. 293, 183-93.

Vance, T.M., Su, J., Fontham, E.T., Koo, S.I., Chun, O.K. 2013. Dietary antioxidants and prostate cancer: a review. Nutr. Cancer. 65(6), 793-801.

Vogt, T.M., Mayne, S.T., Graubard, B.I., Swanson, C.A., Sowell, A.L., Schoenberg, J.B., Swanson, G.M., Greenberg, R.S., Hoover, R.N., Hayes, R.B., Ziegler, R.G. 2002. Serum lycopene, other serum carotenoids, and risk of prostate cancer in US Blacks and Whites. Am. J. Epidemiol. 155, 1023-32.

Weinstein, S.J., Wright, M.E., Pietinen, P., King, I., Tan, C., Taylor, P.R., Virtamo, J., Albanes D. 2005 Serum alphatocopherol and gamma-tocopherol in relation to prostate cancer risk in a prospective study. J. Natl. Cancer Inst. 97, 396-9.

Willcox, J.K., Ash, S.L., Catignani, G.L. 2004. Antioxidants and prevention of chronic disease. Review. Crit. Rev. Food Sci. Nutr. 44, 275-95.

Willis, M.S., Wians, F.H. 2003. The role of nutrition in preventing prostate cancer: a review of the proposed mechanism of action of various dietary substances. Clin. Chim. Acta 330, 57-83.

World Cancer Research Fund / American Institute for Cancer Research. Food, Nutrition, Physical Activity, and the Prevention of Cancer: a Global Perspective. Washington, DC: AICR, 2007.

Yang, G., Gao, Y., Ji, B. 1994. Dietary factors and cancer of the colon and rectum in a population based case-control study in Shanghai. Zhonghua Liu Xing Bing Xue Za Zhi 15, 299303.

Young, I., Woodside, J. 2001. Antioxidants in health and disease. J. Clin. Pathol. 54, 176-86.

Zickute, J., Strumylaite, L., Dregval, L., Petrauskiene, J., Dudzevicius, J., Stratilatovas E. 2005. Vegetables and fruits and risk of stomach cancer. Medicina (Kaunas). 41, 733-40. 


\title{
Резиме
}

\section{Природните антиоксиданси во превенција на малигни заболувања}

\author{
Зорица Арсова-Сарафиновска ${ }^{1}$ и Александар Ј. Димовски ${ }^{2}$

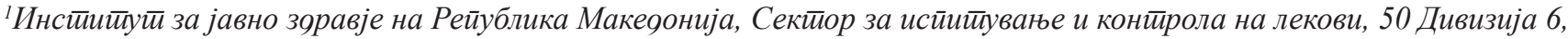 \\ 1000 Скойје, Рейублика Макеоонија

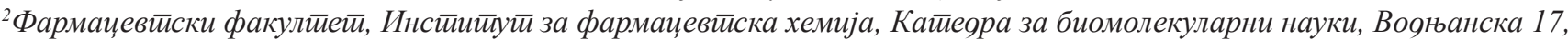 \\ 1000 Скойје, Рейублика Макеоонија
}

Клучни зборови: оксидативен стрес; реактивни кислородни форми; реактивни азотни форми; природни антиоксиданси; канцер.

Оксидативниот стрес е неизбежна последица на аеробниот живот. Во тек на клеточната респирација и продукција на високоенергетски соединенија во митохондриите се создава широк спектар на реактивни кислородни (РКФ) и азотни форми (РАФ) кои можат директно да ја нападнат молекулата на ДНК. Според теоријата на оксидативен стрес, стареењето и дегенеративните болести настануваат како резултат на акумулација на оксидативно оштетување на критични молекули (ДНК, липиди, протеини) во тек на животниот век. Познато е дека тешкиот оксидативен стрес доведува мутација на тумор супресорните гени (рани настани во процесот на карциногенеза), но се поврзува и со стадиумите на промоција и прогресија. Човечкиот организам развил одбранбен механизам за заштита од оксидативниот стрес, кој го сочинуваат систем на антиоксиданси, создадени in situ или обезбедени преку храна или суплементи. Според податоците добиени од студии изведени на клеточни култури или со експериментални животни, антиоксидансите можат да го забават, дури и спречат развојот на малигните процеси. Меѓутоа, поновите податоци добиени со анализа на изведени кохортни студии, студии на случаи, и/или еколошки студии се контрадикторни. Заради тоа, цел на овој преглед е да се резимираат податоците од објавените студии и да се идентификуваат ефективни третмани со природни антиоксиданси. 



\title{
High-throughput SPE-LC-MS/MS method for determination of indapamide in human serum
}

\author{
Natalija Nakov ${ }^{1 *}$, Kristina Mladenovska ${ }^{1}$, Dimche Zafirov $^{2}$, Aleksandar Dimovski ${ }^{1}$, \\ Rumenka Petkovska ${ }^{1}$, Aneta Dimitrovska ${ }^{1}$, Zoran Kavrakovski ${ }^{1}$ \\ ${ }^{1}$ Faculty of Pharmacy, University of "Ss Cyril and Methodius", 1000 Skopje, Republic of Macedonia \\ ${ }^{2}$ Institute of Preclinical and Clinical Pharmacology and Toxicology, Medical Faculty, University of "Ss Cyril and \\ Methodius", 1000Skopje, Republic of Macedonia
}

Received: February 2013; Accepted: April 2013

\begin{abstract}
Simple, automated SPE procedure combined with fast LC-MS/MS chromatographic separation resulted in obtaining high-throughput LC-MS/MS method for determination of indapamide in serum. The SPE procedure was performed on polymeric mixed-mode sorbent and the analytes were quantitated using electrospray ionization in positive mode. The recovery of indapamide and internal standard were $89.25-$ $90.36 \%$ and $79.10 \%$, respectively. Experimentally it was confirmed that the matrix effect had a negligible effect of ionization efficiency. The validation data showed that the proposed method provides accurate and reproducible results in range of $0.50-50 \mathrm{ng} / \mathrm{mL}$. In addition, a comparison was made between the method for determination of indapamide in serum and in blood (develop in our previously work) regarding the extraction procedure and matrix effect.
\end{abstract}

Keywords: indapamide; human serum, solid-phase extraction, liquid chromatography-tandem mass spectrometry

\section{Introduction}

Indapamide is a sulphonamide derivative pharmacologically related to thiazide diuretics. Indapamide is preferentially and reversibly taken up by the red blood cells, but it is also highly bound to plasma proteins (Dollery, C. 1999). The concentration of indapamide, for the needs of pharmacokinetic studies, can be estimated from blood or plasma/serum. The possibility of lysis of the erythrocytes makes its determination from blood more appropriate and precise. There are number reports concerning determination of indapamide in whole blood using high-performance

\footnotetext{
* MSci Natalija Nakov

phone: +3892 3126032; fax: + 38923123054

email: natalijan@ff.ukim.edu.mk
}

liquid chromatography with ultraviolet detection (HPLCUV) and liquid chromatography coupled with mass spectrometry (LC-MS) (Miller et al., 1993; Zendelovska et al., 2003; Tang et al., 2005; Hang et al., 2006; Jain et al., 2006; Nakov et al., 2013).

However, the literature data have shown that indapamide plasma/serum concentrations can also be used for clinical applications. Several HPLC-UV methods for determination of indapamide in plasma have been published (Choi et al., 1982; Gaetani et al., 1986; Zendelovska et al., 2003). In the recent years the number of reported LC-MS methods for estimation of indapamide in human plasma/ serum increases, mainly due to the specificity and sensitivity of the MS detector. Albu et al. (2005) and Ding et al. (2006) described LC-MS method using liquid-liquid extraction (LLE) procedure for determination of indap- 
amide in serum under isocratic conditions, within $11 \mathrm{~min}$ and $5 \mathrm{~min}$, respectively. Another published LC-MS method (Chen et al., 2006) employs LLE and gradient elution with a runtime of $7.5 \mathrm{~min}$. LC-MS/MS method using automated 96-well SPE for determination of indapamide in human serum was described by Morihisa et al (2008). Even though the method showed excellent sensitivity, the separation was performed under gradient elution within $16 \mathrm{~min}$.

In our previously work, we have developed an automated SPE-LC-MS/MS method for determination of indapamide in human whole blood within 3 minutes (Nakov et al., 2013). The objective of this work was to develop an automated SPE procedure for determination of indapamide in serum taking the advantage of the fast chromatographic separation attained in the previous work. The proposed method was validated in order to establish that it will continue to provide accurate, precise and reproducible results during the real study sample analysis. In addition, comparison of the two methods (determination of indapamide in serum vs. blood) in terms of extraction procedure and matrix effect was done.

\section{Experimental}

\section{Chemicals and standards}

Indapamide (purity 97.6\%) and zolpidem tartarate reference standards were purchased from EDQM (Strasbourg, France). Methanol, acetonitrile, water (MS grade) and ammonium acetate and potassium hydrogen phosphate dibasic (analytical grade) were supplied from Sigma-Aldrich, Germany. Formic acid and potassium hydroxide pellets (analytical grade) were purchased from Merck, Germany.

\section{Instrumentation and experimental conditions}

The HPLC-MS/MS system consisted of Shimadzu LC-30 Nexera coupled to a Shimadzu LCMS 8030 triple quadrupole mass spectrometer with an electrospray ionization (ESI) interface. Data were acquired using Shimadzu LCMS LabSolution software. Automated SPE was performed on RapidTrace workstation (Biotage AB), controlled by RapidTrace V 2.0 software.

Chromatographic separation was achieved on Kinetex C18 column $(100 \times 2.1 \mathrm{~mm}, 1.7 \mu \mathrm{m}$ partical size $)$ using acetonitrile and $2 \mathrm{mM}$ ammonium acetate (added $0.5 \mathrm{~mL}$ formic acid in $1 \mathrm{~L}$ buffer) in ratio $90: 10(v / v)$ as a mobile phase. The flow rate was $0.2 \mathrm{~mL} / \mathrm{min}$ and the injection volume $10 \mu \mathrm{L}$. The column temperature was $30^{\circ} \mathrm{C}$ and the autosampler temperature was set at $15{ }^{\circ} \mathrm{C}$. The run time was 2.5 minutes. Mass spectrometric conditions were as follows: drying gas $11.0 \mathrm{~L} / \mathrm{min}$, nebulizing gas $2.4 \mathrm{~L} / \mathrm{min}$, desolvation line temperature $280^{\circ} \mathrm{C}$, heat block temperature $430{ }^{\circ} \mathrm{C}$, interface voltage $4.5 \mathrm{kV}$ and collision gas $230 \mathrm{kPa}$. Indapamide and zolpidem tartarate (internal standard, IS) were quantitated in multiple reaction monitoring (MRM) using the transition of $\mathrm{m} / \mathrm{z} 366.1 \rightarrow 132.15$ and $309.0 \rightarrow$
236.10 respectively. The collision energy applied was $20 \mathrm{~V}$ for indapamide and $35 \mathrm{~V}$ for the IS.

\section{Preparation of calibration standards (CS) and quality control (QC) samples}

Indapamide and zolpidem tartarate were dissolved in methanol to yield a stock solution of $1 \mathrm{mg} / \mathrm{mL}$ each. Indapamide working solutions, in concentrations ranging from 0.50 to $50 \mathrm{ng} / \mathrm{mL}$, were prepared by serial dilution of the stock solution. The calibration standards (CS) and quality control (QC) samples were prepared by spiking $50 \mu \mathrm{L}$ of each working standard solution with $150 \mu \mathrm{L}$ blank human serum. IS working solution of $600 \mathrm{ng} / \mathrm{mL}$ was prepared by dilution of IS stock solution in methanol.

\section{Sample preparation by automated solid-phase extraction (SPE) procedure}

A volume of $200 \mu \mathrm{L}$ of a CS or QC samples was placed in a testing tube and $20 \mu \mathrm{l}$ IS working solution and $400 \mu \mathrm{L}$ of $100 \mathrm{mM} \mathrm{K} \mathrm{HPO}_{4}(\mathrm{pH} 10.5)$ were added and homogenized by vortex-mixed. Phenomenex Strata-X-Drug N Polymer RP $(60 \mathrm{mg} / 3 \mathrm{~mL})$ cartridges were used for analyte extraction. The automated SPE was carried out on RapidTrace workstation according to following steps: a) loading $0.5 \mathrm{~mL}$ sample; b) washing with $2 \mathrm{~mL}$ mixture of methanol and water in ratio 10:90 $(\mathrm{v} / \mathrm{v})$; c) drying for $3 \mathrm{~min}$ with $\mathrm{N}_{2}$ gas; d) elution with $1 \mathrm{~mL}$ methanol. The eluate was transferred to vials and $10 \mu \mathrm{l}$ was injected into the LC-MS/ MS system.

\section{Bioanalytical method validation}

A validation according to the EMA guideline was performed for the determination of indapamide in human serum (EMA 2011).

For selectivity assessment, blank samples from six different subjects were tested using the proposed method. The obtained results were compared with the lower limit QC samples $(0.50 \mathrm{ng} / \mathrm{mL})$.

The effect of serum constituents over the ionization efficinecy of indapamide and IS was determined by comparing the responses of the post-extracted blank serum (obtained from 6 different donors) spiked with analyte and IS with response of analyte from neat standard samples (analyte and IS spiked with methanol instead of blank serum). The matrix factor (MF) for indapamide was determined at low QC and high QC, whereas the MF for IS was determinate at single concentration of $20 \mathrm{ng} / \mathrm{mL}$. The IS normalized MF was obtained by dividing the indapamide MF by the MF of IS.

A calibration curve was constructed from blank sample (serum sample without analyte and IS), a zero sample (serum with IS) and seven non-zero samples covering the range from $0.50-50 \mathrm{ng} / \mathrm{mL}$. The calibration curves ob- 
tained from six days were fitted to the ordinary linear regression through the measurement of the peak area ratio of the analyte to IS. The accuracy and precision of the method were evaluated by within-run $(n=5)$ and between-run $(n=30)$ assay using QC samples at concentrations of 0.50 $\mathrm{ng} / \mathrm{mL}$ (lower limit QC); $1 \mathrm{ng} / \mathrm{mL}$ (low QC), $25 \mathrm{ng} / \mathrm{mL}$ (medium QC) and $40 \mathrm{ng} / \mathrm{mL}$ (high QC). For within-run accuracy and precision, five samples per concentration were prepared and analyzed in the same day. For between-run accuracy and precision, five determinations per concentration per run from three runs were analyzed on two different days.

Stability of indapamide in human serum was evaluated by analyzing replicates $(n=3)$ that were exposed to different conditions ( $24 \mathrm{~h}$ at room temperature, $12 \mathrm{~h}$ in autosampler, three freeze-thaw cycles and 1 month stored at $-20{ }^{\circ} \mathrm{C}$ ) at two concentrations ( $1 \mathrm{ng} / \mathrm{mL}$ and $40 \mathrm{ng} / \mathrm{mL})$. The QC samples are analyzed against calibration curve and compared to the nominal concentrations. The stability of stock solutions of the analytes which were stored at room temperature for $24 \mathrm{~h}$ and one month at $2-8{ }^{\circ} \mathrm{C}$ was also tested.

\section{Results and discussion}

\section{Method development}

The strategy for obtaining high-throughput bioanalytical method is composed of fast chromatographic separation on one hand and automated; fast and simple sample cleanup procedure on the other hand. The fast chromatograph- ic separation is the first segment, which plays an important role in obtaining high sample throughput. The existing literature data have shown that the use of fully-porous particles (Chen et al., 2006; Ding et al., 2006 and Morihisa et al., 2008) or monolithic columns (Albu et al., 2005) did not provide separation of indapamide within short runtime. In our previous work, method for determination of indapamide in human whole blood using core-shell stationary phase was developed (Nakov et al., 2013). These particles are not fully porous; analytes spend less time diffusing into and out of the pores, resulting in faster mass transfer and shorter run time. It was observed that under the optimized chromatographic conditions indapamide and IS eluted in less than 3 minutes. Prompted by these results, the reported chromatographic conditions were applied in the new method for determination of indapamide in human serum. The retention time of indapamide and IS extracted from human serum was $1.55 \mathrm{~min}$ and $1.66 \mathrm{~min}$, respectively (Fig. 1 ), in contrast to 11 min reported by Albu et al. (2005) and 16 min reported by Morihisa et al. (2008). The benefit from short analysis time is not only in the increased sample throughput, but also in dramatically decreased solvent consumption.

One of the important factors in a quality quantitative method is the availability of a quality IS that plays an important role in normalizing (and therefore reducing) variability (Mulvana 2010). Zolpidem tartarate was chosen as internal standard because it not only posses similar physicochemical properties as the analyte, but it also coelute with the analyte and, thus, will experience the same ionization suppression/enhancement as the analyte.
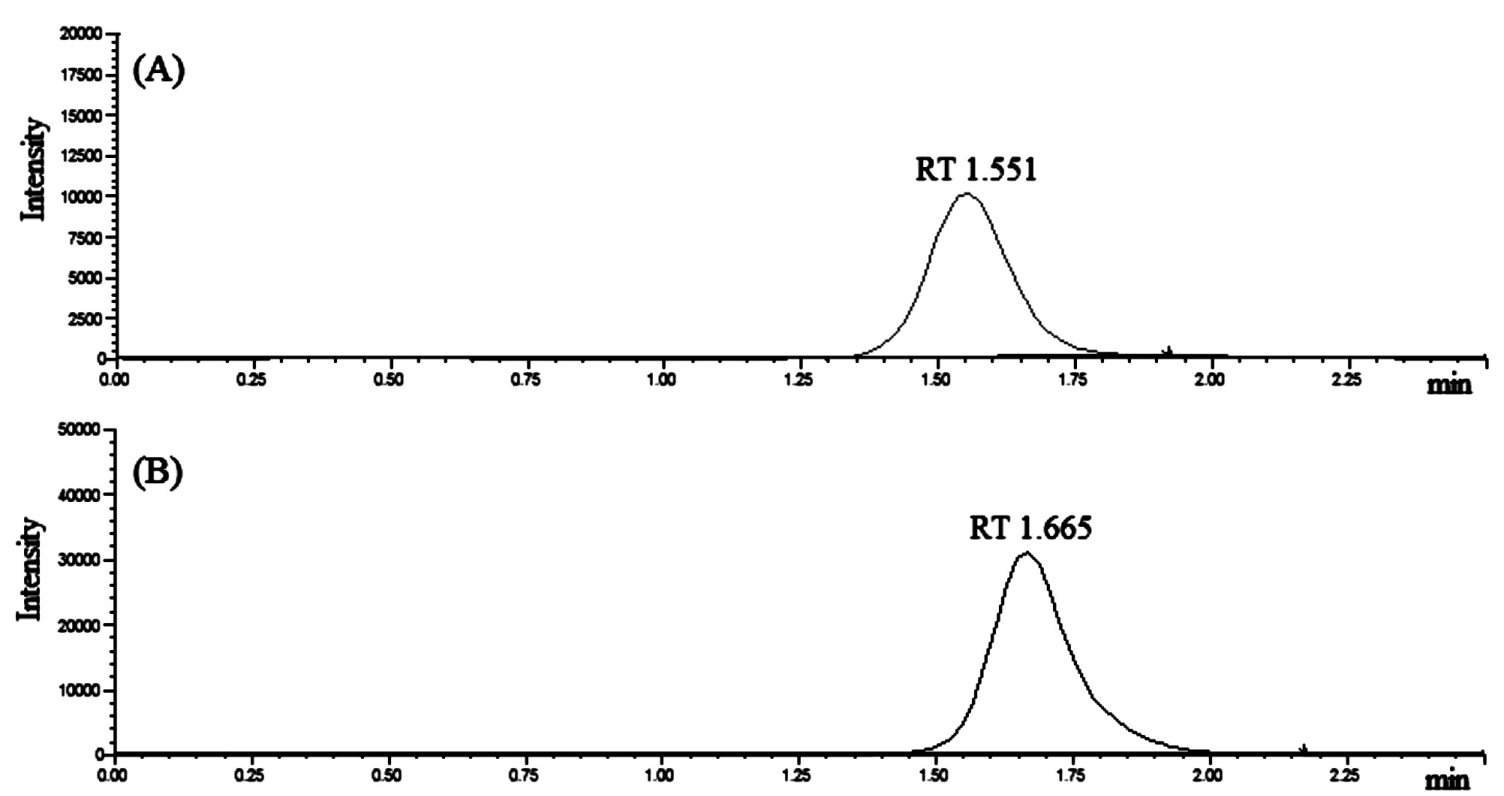

Fig. 1 MRM chromatograms for indapamide (A) and internal standard (B) from medium CS. Conditions: Kinetex C18 column, mobile phase consisting of acetonitrile: $2 \mathrm{mM}$ ammonium acetate $(90: 10 \mathrm{v} / \mathrm{v})$, containing $0.5 \mathrm{~mL}$ formic acid in $1 \mathrm{~L}$ buffer; flow rate of $0.2 \mathrm{~mL} / \mathrm{min}$ 


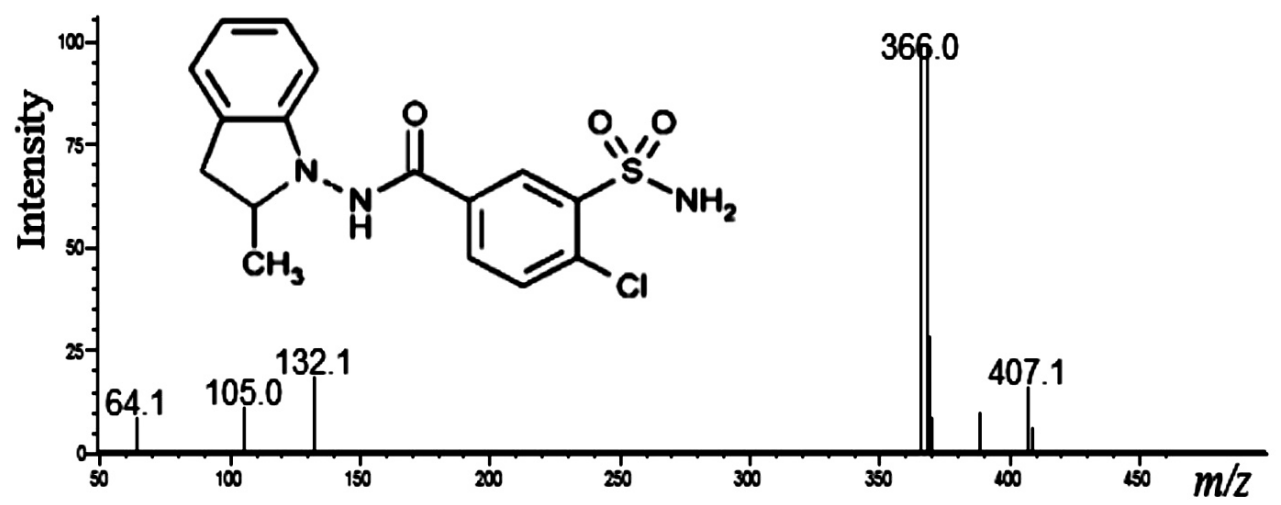

Fig. 2 Chemical structure and $\mathrm{Q}_{3}(+)$ mass scan spectrum of indapamide.

The indapamide molecule contains $\mathrm{NH}_{2}$ group, which could be ionized efficiently using ESI+ mode. The chemical structure and the $\mathrm{Q}_{3}(+)$ mass scan spectrum of indapamide are presented in Figure 2. The molecular weight of indapamide is $365 \mathrm{~g} / \mathrm{mol}$, so $\mathrm{m} / \mathrm{z} 366.0$ correspond to protonated molecular ion $[\mathrm{M}+\mathrm{H}]^{+}$of indapamide and ion with $m / z 132.1$ correspond to the major fragment. The ion mass of $m / z 407.1$ probably comes from the adduct ion of indapamide with acetonitrile; $m / z 64.1$ derives from ammonium formate cluster $\left[\mathrm{CHOONH}_{4}+\mathrm{H}\right]^{+}$and the possible origin of the ion with $\mathrm{m} / \mathrm{z} 105.0$ is from acetonitrile/ ammonium formate cluster.

The second part from obtaining high-throughput bioanalytical method, as stated above, is having an automated, fast and simple sample clean-up procedure. For that purpose our research was towards developing SPE which as a technique has number of advantages over LLE. The SPE procedure was performed on polymeric mixed-mode sorbent which can retain analytes by several different sorbentanalyte interactions. Indapamide is weak basic compound (pKa 8.3, Dollery, C. 1999), so its retention on the sorbent can be achieved as ionic or as neutral form. In that direction experiments were made using buffer at $\mathrm{pH}$ two units below and two units above its $\mathrm{pKa}$ value. The best results were obtained using buffer $\left(100 \mathrm{mM} \mathrm{KH}_{2} \mathrm{PO}_{4}\right)$ at $\mathrm{pH}$ 10.5. In comparison, the extraction of indapamide from blood using buffer at $\mathrm{pH} 6.8$, which is close to physiolog- ical $\mathrm{pH}$, was performed. Optimization of the washing step of the SPE is crucial, in one hand to remove matrix components which otherwise may impose ionization suppression/enhancement of the analytes and to obtain satisfactory recovery on the other hand. The use of methanol and water in ratio 20:80 $(v / v, \%)$ as a washing solvent resulted in low recovery (around 60\%). To avoid washing of the analyte from the cartridge, methanol and water in ratio 10:90 $(v / v)$ was used, but this led to unsatisfactory removal of the matrix components. The matrix effect observed under these conditions, in term of suppression of ionization was around $25 \%$. This problem was solved when larger volume of washing solvent was used $(2 \mathrm{~mL}$ instead of $1 \mathrm{~mL})$. In comparison, removal of matrix effect from whole blood, due to its complexity, was accomplished using $4 \mathrm{~mL}$ washing solvent.

The extraction yield under the optimized conditions is presented in Table 1. Recovery was calculated by comparing mean peak areas obtained from extraction of QC samples and extracted blank serum spiked with the corresponding concentrations of indapamide and IS. The optimized SPE procedures for extraction of indapamide from serum and blood gave similar recovery values. The mean recovery for indapamide from serum was around $90 \%$ and from blood was around $92 \%$. The mean recovery for IS was around $80 \%$ in either case.

Table 1. Absolute recovery of indapamide and internal standard from spiked serum samples

\begin{tabular}{lllc}
\hline \hline Compound & Concentration $(\mathrm{ng} / \mathrm{mL})$ & Recovery $(\%)$ & Variability $(\mathrm{CV}, \%)$ \\
\hline \multirow{2}{*}{ Indapamide } & $1 \mathrm{ng} / \mathrm{mL}$ (low QC) & $89.25(\mathrm{n}=3)$ & 2.45 \\
& $25 \mathrm{ng} / \mathrm{mL}$ (medium QC) & $90.36(\mathrm{n}=3)$ & 1.87 \\
& $40 \mathrm{ng} / \mathrm{mL}$ (high QC) & $89.75(\mathrm{n}=3)$ & 1.13 \\
Internal standard & $20 \mathrm{ng} / \mathrm{mL}$ & $79.10(\mathrm{n}=9)$ & 1.56 \\
\hline
\end{tabular}



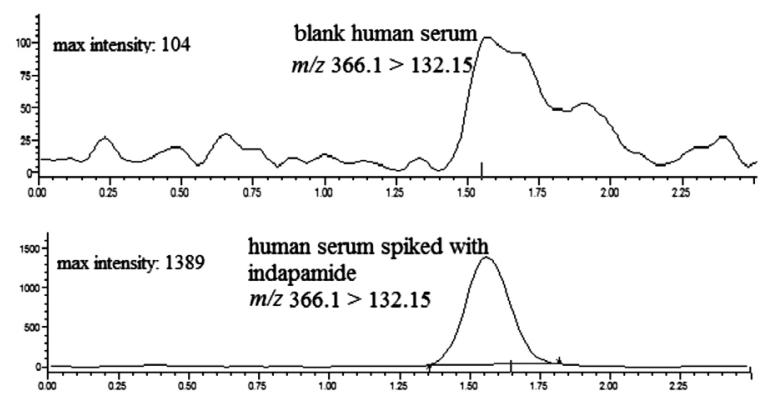

(a)
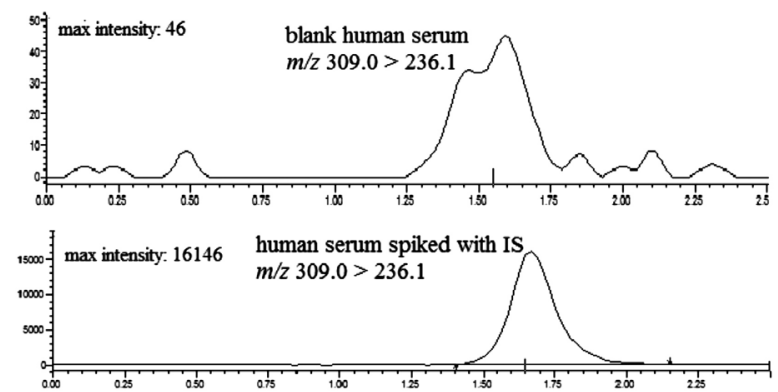

(b)

Fig. 3 MRM chromatogram for: a) indapamide $\mathrm{m} / \mathrm{z}$ $366.1>132.15$ in blank human serum (top); blank serum spiked with indapamide $(0.50 \mathrm{ng} / \mathrm{mL}$, bottom); b) internal standard $\mathrm{m} / \mathrm{z} 309>236.10$ in blank human serum (top); blank serum spiked with IS (20 ng/mL, bottom)

\section{Method validation}

The selectivity met the acceptance criteria that the mean response obtained from the blank samples was less than $20 \%$ of the lower limit quantification for indapamide and less than 5\% for IS. Representative chromatograms of lower limit QC and blank human serum are presented in Figure 3.

Matrix effects are the alteration (suppression or enhancement) of the ionization efficiency by the presence of coeluting substances. These effects are not seen in the chromatogram but have deleterious impact on the method accuracy, precision and sensitivity (Taylor 2005). In this study, the matrix effect was assessed through determination of the IS normalized MF (EMA 2011). For that purpose six different sources of matrices were used. It was found that the coefficient of variation ( $\mathrm{CV} \%$ ) of the IS normalized $\mathrm{MF}$ at two concentration levels were within the acceptance criteria of $15 \%$ (2.87\% for LQC and $3.15 \%$ for high QC). The matrix effect assessment has demonstrated that the inter-subject variability does not affect the reproducibility of the assay.

The indapamide MF obtained from serum was around $97 \%$, which means that the ionization suppresion was almost 3\%. For comparison, the indapamide MF obtained from blood indicates that the matrix effect is almost $8 \%$, resulting in higher suppression of the ionization efficiency (Table 2).

Table 2. Comparison of indapamide MF (\%) obtained from serum and from blood

\begin{tabular}{lcc}
\hline \hline & \multicolumn{2}{c}{ Indapamide MF (\%) } \\
& Low QC & High QC \\
\hline Serum $(\mathrm{n}=6)$ & 96.45 & 97.84 \\
Blood $(\mathrm{n}=6)$ & 91.60 & 92.26 \\
\hline
\end{tabular}

The calibration curve for indapamide was establish in the range from $0.50-50 \mathrm{ng} / \mathrm{mL}$ using seven-point calibration curve from six different days. The regression equation was $y=0.321389 x+0.00106751$ with a coefficient of determination 0.9997 . The $\%$ accuracy observed for the back-calculated concentrations for the calibration curves was within 94.80- 107.91; while the \% precision values ranged from 0.31-6.60.

The results for accuracy and precision are presented in Table 3 . The accuracy was expressed as the $\%$ deviation for the lower limit QC, low QC, medium QC and high QC. The within-run accuracy ranged between $-3.46 \%$ and $9.15 \%$; while between-run ranged from $-4.73 \%$ and $10.12 \%$. The precision was expressed as $\mathrm{CV} \%$. The within-run precision ranged between $2.45 \%$ and $4.23 \%$. The between-run precision was between $2.87 \%$ and $5.14 \%$. The method met the recommended acceptance criteria $(\%$ Deviation and $\% \mathrm{CV}$ $\pm 20 \%$ for lower limit QC and $\pm 15 \%$ for low QC, medium QC and high QC).

Table 3. Accuracy and precision of indapamide in human serum

\begin{tabular}{lccccc}
\hline \hline $\begin{array}{c}\text { Quality control } \\
\text { samples }\end{array}$ & $\begin{array}{c}\text { Nominal conc. } \\
(\mathrm{ng} / \mathrm{mL})\end{array}$ & $\begin{array}{c}\text { Within-run assay }(\mathrm{n}=5) \\
\text { Precision } \\
(\mathrm{CV} \%)\end{array}$ & $\begin{array}{c}\text { Between-run assays }(\mathrm{n}=30) \\
\text { Deviation }(\%)\end{array}$ & $\begin{array}{c}\text { Precision } \\
(\mathrm{CV} \%)\end{array}$ \\
\hline Low limit QC & 0.50 & 9.15 & 4.23 & 10.12 & 5.14 \\
Low QC & 1 & -3.46 & 4.04 & -4.73 & 4.40 \\
Medium QC & 25 & 1.22 & 2.45 & 1.65 & 2.87 \\
High QC & 40 & -1.24 & 2.62 & -2.74 & 3.03 \\
\hline
\end{tabular}


Table 4. Stability of indapamide in human serum $(n=3)$

\begin{tabular}{|c|c|c|c|c|}
\hline \multirow{2}{*}{ Nominal concentration } & \multicolumn{2}{|c|}{$1.0 \mathrm{ng} / \mathrm{mL}$} & \multicolumn{2}{|l|}{$40 \mathrm{ng} / \mathrm{mL}$} \\
\hline & Recovery (mean) $(\%)$ & $\mathrm{CV}(\%)$ & Recovery (mean) (\%) & $\mathrm{CV}(\%)$ \\
\hline $24 \mathrm{~h}$ room temperature & 98.89 & 2.15 & 101.25 & 2.37 \\
\hline Autosampler stability (after 12h) & 99.23 & 1.78 & 100.57 & 1.95 \\
\hline Three freeze-thaw cycles & 95.43 & 3.45 & 97.25 & 5.14 \\
\hline Long term stability $\left(-20^{\circ} \mathrm{C}\right)$ & 92.14 & 4.27 & 95.27 & 6.62 \\
\hline
\end{tabular}

The stability of indapamide in human serum under various conditions is presented in Table 4 . The results were found to be within the acceptable limits ( $\pm 15 \%$ of the nominal concentration). The stability data of indapamide indicated that the analyte is stable in serum at room temperature for $24 \mathrm{~h}$, after $12 \mathrm{~h}$ in autosampler, three freeze-thaw cycles and after 3 month stored at $-20^{\circ} \mathrm{C}$. The stock solutions of indapamide and IS were stable at room temperature for $24 \mathrm{~h}$ and at $2-8^{\circ} \mathrm{C}$ for one month.

\section{Conclusions}

In this research we have developed an automated SPE procedure which in combination with fast chromatographic separation resulted in obtaining high-throughput LCMS/MS method for determination of indapamide in human serum. The benefit from automated SPE procedure is in its simplicity, good recovery and low variability values. The results of all validation parameters have shown that the present method will generate reliable bioanalytical data during the real study sample analysis. All the abovementioned makes the proposed method suitable for analyzing large number of samples involved in pharmacokinetic studies.

\section{References}

Albu, F., Georgita, C., David, F., Medvedovic, A., 2005. Liquidchromatography-electrospray tandem mass spectrometry method for determination of indapamide in serum for single/ multiple dose bioequivalence studies of sustained release formulations. J Chromatogr B Analyt Technol Biomed Sci 816 (1-2), 35-40.

Chen, W.D., Liang, Y., Zhang, H.,Li, H., Xiong, Y., Wang, G.J., Xie, L., 2006. Simple, sensitive and rapid LC-MS method for the quantification of indapamide in human plasmaapplication to pharmacokinetic studies. J Chromatogr B 842, 58-63.

Choi, R.L., Rosenberg, M., Grebow, P.E., Huntley, T.E., 1982. High performance liquid chromatographic analysis of indapamide (RHC 2555) in urine, plasma and blood. J Chromatogr 230 (1), 181-187.

Ding, L., Yang, L., Liu, F., Ju, W., Xiong, N., 2006. A sensitive LC-ESI-MS method for the determination of indapamide in human plasma: method and clinical applications. J Pharm Biomed Anal 42 (2), 213-217.
Dollery, C., 1999. Therapeutic drugs, second edition. Churchill Livingstone, Edinburgh, United Kingdom

Eeckhaut, A.V., Lanckmans, K., Sarre, S., Smolders, I., Michotte, Y., 2009. Validation of bioanalytical LC-MS/MS assays: Evaluation of matrix effects. J Chromatogr B 877, 21982207.

European Medicines Agency. Guideline on validation of bioanalytical methods. Committee for Medical Products for Human Use (CHMP).2011. http://www.ema.europa.eu/docs/ en GB/document library/Scientific guideline/2011/08/ WC 500109686.pdf

Gaetani, E., Laureri, C.F., Vitto, M., Elie, G.F., Novarini, A., 1986. Determination of indapamide in plasma by HPLC. Boll Chim Farm 125 (1), 35-37.

Hang, T.J., Zhao, W., Liu, J., Song, M., Xie, Y., Zhang, Z., Shen, J., Zhang, Y., 2006. A selective HPLC method for the determination of indapamide in human whole blood: application to a bioequivalence study in Chinese volunteers. J Pharm Biomed Anal 40 (1), 202-205.

Miller, R.B., Dadgar, D., Lalande, M., 1993. High performance liquid chromatographic method for the determination of indapamide in human whole blood. J Chromatogr 614 (2), 293-298.

Morihisa, H., Fukata, F., Muro, H., Nishimura, K.I., Makino, T., 2008. Determination of indapamide in human serum using 96-well solid-phase extraction and high-performance liquid chromatography-tandem mass spectrometry (LC-MS/MS). J Chromatogr B 870, 126-130.

Mulvana, D., 2010. Critical topics in ensuring data quality in bioanalytical LC-MS method development. Bioanal 2 (6), 1051-1072.

Nakov, N., Mladenovska, K., Labacevski, N., Dimovski, A., Petkovska, R., Dimitrovska, A., Kavrakovski, Z., 2013. Development and validation of automated SPE-LC-MS/MS method for determination of indapamide in human whole blood and its application on real study samples. Biomed Chromatogr 27, 1540-1546.

Taylor. P.J., 2005. Review Matrix effects: The Achilles heel of quantificatative high-performance liquid chromatographyelectrospray-tandem mass spectrometry. Clin Biochem 38, 328-334.

Zendelovska D, Stafilov T, Stefova M. 2003. Optimization of solid-phase extraction method for determination of indapamide in biological fluids using high performance liquid chromatography. J Chromatogr B 788 (1), 199-206.

Zhou, S., Song, Q., Tang, Y., Naidong. W., 2005. Critical review of development, validation, and transfer for high throughput bioanalytical LC-MS/MS methods. Curr Pharmaceut Anal, $1(1), 3-14$. 


\title{
Резиме
}

\section{Високо-продуктивен LC-MS/MS метод за определување на индапамид во серум}

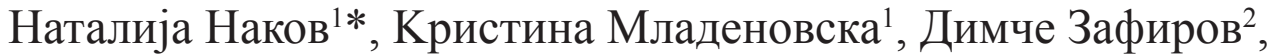 \\ Александар Димовски ${ }^{1}$, Руменка Петковска ${ }^{1}$, Анета Димитровска ${ }^{1}$ \\ и Зоран Кавраковски ${ }^{1}$

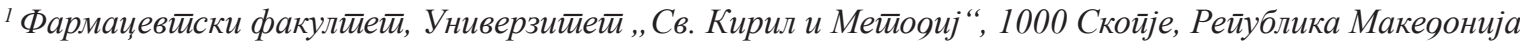

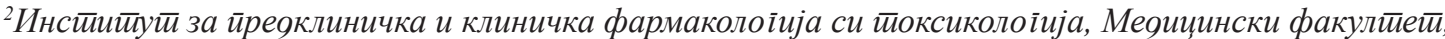 \\ Универзииееӣ „Св. Кирил и Мейояиј“, 1000 Скойје, Рейублика Макеоонија
}

Клучни зборови: индапамид, серум, цврсто-фазна екстракција, течна хроматографија спрегната со тандем масена спектрометрија

Едноставната, автоматизирана постапка на цврсто-фазна екстракција (solid-phase extraction, SPE) комбинирана со течна хроматографија спрегната со тандем масена спектрометрија (liquid chromatography-tandem mass spectrometry, LC-MS/MS) резултираше со добивање на високо-продуктивен метод за определување на индапамид во серум. За SPE користен е полимерен сорбент, додека пак за квантитативното определување на аналитите користена е електроспреј јонизација во позитивен мод. Добиените вредности за приносот на екстрактивната постапка се движат од 89,25-90,36\% за индапамид и 79, $10 \%$ за внатрешениот стандард. Експериментално беше потврдено дека матрикс ефектот има незначително влијание врз ефикасноста на јонизацијата. Валидацијата на методот покажа дека предложениот метод обезбедува точни, прецизни и репродуцибилни резултати во опсег од 0,50-50 ng/mL. Дополнително, направена е споредба на овој методот со методот за определување на индапамид во крв (развиен во наше претходно истражување) по однос на постапката за екстракција и матрикс ефектот. 



\title{
Chemical composition and antimicrobial activity of leaves essential oil of Juniperus communis (Cupressaceae) grown in Republic of Macedonia
}

\author{
Floresha Sela ${ }^{1}$, Marija Karapandzova ${ }^{1}$, Gjose Stefkov $^{1}$, Ivana Cvetkovikj ${ }^{1 *}$, \\ Elena Trajkovska-Dokik ${ }^{2}$, Ana Kaftandzieva², Svetlana Kulevanova ${ }^{1}$ \\ 'Institute of Pharmacognosy, Faculty of Pharmacy, University”'Ss. Cyril and Methodius", str. Majka Tereza 47, 1000 \\ Skopje, R. Macedonia \\ ${ }^{2}$ Institute of Microbiology and Parasitology, Faculty of Medicine, University"Ss. Cyril and Methodius", str. 50 Divizija \\ No.6, 1000 Skopje, R. Macedonia
}

Received: June 2013; Accepted: July 2013

\begin{abstract}
Chemical composition and antimicrobial activity of essential oils isolated from leaves of three different samples of wild growing Juniperus communis L. (Cupressaceae) from R. Macedonia was investigated. Essential oil yield ranged from 7.3 to $9.0 \mathrm{ml} / \mathrm{kg}$. Performing GC/ FID/MS analysis, ninety components were identified, representing 86.07-93.31\% of the oil. The major components of the leaves essential oil (LEO) were $\alpha$-pinene (21.37-28.68\%) and sabinene (2.29-16.27\%), followed by limonene, terpinen-4-ol, $\beta$-elemene, trans-(E)-caryophyllene, germacrene $\mathrm{D}$ and $\delta$-cadinene. Antimicrobial screening of the LEO was made by disc diffusion and broth dilution method against 16 bacterial isolates of Gram positive and Gram negative bacteria and one strain of Candida albicans. Two bacteria, Staphylococcus aureus and Streptococcus pyogenes were sensitive to antimicrobial activity of LEO (MIC $=125 \mu 1 / \mathrm{ml}$ ). Additionally, LEO showed moderate antimicrobial activity against Streptococcus agalactiae, Haemophilus influnzae, Corynebacterium spp. and Campylobacter jejuni (MIC > $500 \mu \mathrm{l} / \mathrm{ml}$ ). Candida albicans, Staphylococcus epidermidis, Acinetobacter spp., Salmonella enteritidis, Shigella flexneri, Klebsiella pneumonia, Pseudomonas aeruginosa and Proteus mirabilis were completely resistant to the antimicrobial effects of this.
\end{abstract}

Keywords: Juniperus communis, leaves essential oil, oil composition, GC/FID/MS analysis, antimicrobial activity

\section{Introduction}

The common juniper, Juniperus communis $\mathrm{L}$. (Cupressaceae), is an evergreen shrub or small coniferous tree, wide spread through the cool temperate Northern Hemisphere. The above-ground parts, especially leaves and berries of juniper are rich in essential oil that has characteristic aromatic flavour and bitter taste. Due to its diuretic and gastrointestinal properties, common juniper is used as me-

\footnotetext{
*email:ivanacvetkovikj@gmail.com, ivanacvetkovic@yahoo.com
}

dicinal plant for centuries. Juniper oil is used in the pharmaceutical, food and cosmetic industries, as well as for the production of perfumes. Certain beverages (gin) are made with distillation from fermented juniper berries.

According to the literature data, juniper essential oil can be obtained from berries, leaves, wood and seeds by hydrodistillation (Orav et al., 2010a; Chatzopoulou and Katsiotis, 1993; Kumar et al., 2007). The average oil yield varies from 0.5 to $2.5 \%$ (for berries) and from 0.2 to $1.0 \%$ (for needles) (Orav et al., 2010a). Dissimilarities in the oil's yield and the chemical composition can vary from the geo- 
Table 1. Plant samples of Juniperus communis from R. Macedonia

\begin{tabular}{clccc}
\hline \hline \multicolumn{1}{c}{ Species } & \multicolumn{1}{c}{ Locality } & Altitude & $\begin{array}{c}\text { Herbarium voucher } \\
\text { specimen }\end{array}$ & $\begin{array}{c}\text { Sample } \\
\text { abbreviation }\end{array}$ \\
\hline Juniperus communis L. & Jelak (Shara Mtn.) & $1800 \mathrm{~m}$ & $\mathrm{~N}^{\circ} \mathrm{JC}-16 / 10$ & $\mathrm{JcS} / 10$ \\
Juniperus communis L. & Velestovo (Galichica Mtn.) & $1000 \mathrm{~m}$ & $\mathrm{~N}^{\circ} \mathrm{JC}-5.1 . / 11$ & $\mathrm{JcG} / 11$ \\
Juniperus communis L. & Kicevo (Bistra Mtn) & $600 \mathrm{~m}$ & $\mathrm{~N}^{\circ} \mathrm{JC}-1 / 11$ & $\mathrm{JcB} / 11$ \\
\hline
\end{tabular}

graphical location, age and degree of plant ripeness, harvesting methods, distillation techniques and other factors.

There are many publications reporting the essential oil composition of juniper berries and leaves (Orav et al., 2010a; Chatzopoulou and Katsiotis, 1993; Kumar et al., 2007, Ottavioli et al., 2009; Filipowicz et al., 2009; Shahmir et al., 2003; Orav et al., 2010b). Considerable variations in the oil composition were observed depending on the plant origin but often the essential oils were rich in $\alpha$-pinene, sabinene and myrcene, followed by trans-(E)caryophyllene, muurolene, germacrene D and B and humulene (Orav et al., 2010a). As major oxygen containing terpene were terpinen-4-ol (Chatzopoulou and Katsiotis, 1993), rarely citronellol (Koukos and Papadopoulou, 1997) and terpenyl acetate (Angioni et al., 2003).

In vitro antimicrobial (antibacterial and antifungal) activity of the berries essential oil was studied and the results showed strong to moderate antimicrobial activity (Filipowitz et al. 2003; Stassi et al. 1995). Other results from the antimicrobial assessment of the leaves essential oil (LEO) demonstrate no or weak antimicrobial activity against various tested microbial strains (Asili et al., 2008; Angioni et al., 2003).

Common juniper, Juniperus communis, is widely spread shrub throughout the territory of Republic of Macedonia (Micevski, 1998). The berries of this plant are extensively utilized in production of blended teas and other herbal medicinal products, in food industry, as a spice, in production of alcoholic beverages, etc. For years, the juniper berries and the juniper essential oil are exported from R. Macedonia. On the other hand the juniper leaves are used in folk medicine for various purposes. Up to date there is no information of the composition and antimicrobial activity of the leaves' essential oil from Macedonian juniper. Therefore the aim of the present study was to investigate the chemical composition and the antimicrobial activity of the leaves essential oil of Juniperus communis grown wild in R. Macedonia.

\section{Material and methods}

\section{Plant materials}

The terminal twigs of Juniperus communis were collected from tree different localities in R. Macedonia in late autumn 2010 and 2011. Plant identity was verified as Juni- perus communis L. and herbarium voucher specimen were deposited at the Department of Pharmaceutical Botany, Institute of Pharmacognosy, Faculty of Pharmacy, Skopje, R. Macedonia (Table 1).

The plant material was dried at room temperature. Just before essential oil isolation, the juniper leaves were separated and minced properly.

\section{Chemicals}

Dimethylsulfoxide was purchased from Sigma-Aldrich (Steinheim, Germany), sodium chloride and anhydrous sodium sulfate from Merck (Darmstadt, Germany) and from Kemica (Zagreb, Croatia), respectively, while xylene was purchased from Alkaloid (Skopje, R. Macedonia).

\section{Essential oil isolation}

The essential oils were obtained from dried plant material through steam distillation using all glass Clevenger-type apparatus. For that purpose, $20 \mathrm{~g}$ of minced plant material was distilled for 4 hours. After isolation, anhydrous sodium sulfate was added to remove residual water from the oil. The essential oil yield was calculated on dried plant material and was expressed in $\mathrm{ml} / \mathrm{kg}$. For $\mathrm{GC} /$ FID/MS analysis, the essential oil was dissolved in xylene to obtain $1 \mu \mathrm{l} / \mathrm{ml}$ oil solution.

\section{Gas chromatography (GC) and gas chromatography/mass spectrometry $(G C / M S)$}

Essential oil samples were analyzed on Agilent 7890A Gas Chromatography system equipped with FID detector and Agilent 5975C Mass Quadrupole detector as well as capillary flow technology which enables simultaneous analysis of the samples on both detectors. For that purpose, HP-5ms capillary column $(30 \mathrm{~m} \times 0.25 \mathrm{~mm}$, film thickness $0.25 \mu \mathrm{m}$ ) was used. Operating conditions were as follows: oven temperature at $60{ }^{\circ} \mathrm{C}(5 \mathrm{~min}), 1{ }^{\circ} \mathrm{C} / \mathrm{min}$ to 80 ${ }^{\circ} \mathrm{C}(2 \mathrm{~min})$ and $5{ }^{\circ} \mathrm{C} / \mathrm{min}$ to $280{ }^{\circ} \mathrm{C}(5 \mathrm{~min})$; helium as carrier gas at a flow rate of $1 \mathrm{ml} / \mathrm{min}$; injector temperature 260 ${ }^{\circ} \mathrm{C}$ and that of the FID $270{ }^{\circ} \mathrm{C}$. $1 \mu \mathrm{l}$ of each sample was injected at split ratio $1: 1$. The mass spectrometry conditions were: ionization voltage $70 \mathrm{eV}$, ion source temperature 230 
${ }^{\circ} \mathrm{C}$, transfer line temperature $280{ }^{\circ} \mathrm{C}$ and mass range from 50 - $500 \mathrm{Da}$. The MS was operated in scan mode.

\section{Identification of the components}

Identification of the components present in essential oils was made by comparing mass spectra of components in essential oils with those from Nist, Wiley and Adams mass spectra libraries, by AMDIS (Automated Mass Spectral Deconvolution and Identification System) and by comparing literature and estimated Kovat's (retention) indices that were determined using mixture of homologous series of normal alkanes from $\mathrm{C}_{9}$ to $\mathrm{C}_{25}$ in hexane, under the same above mentioned conditions.

The percentage ratio of essential oils components was computed by the normalization method of the GC/FID peak areas without any correction factors.

\section{Antimicrobial activity: Microbial strains and cultures}

16 bacterial isolates representing both Gram positive and Gram negative bacteria and one strain of Candida albicans were used for antimicrobial screening. Five isolates were standard strains (Staphylococcus aureus ATCC 29213, Escherichia coli 25927, Klebsiella pneumoniae ATCC 700603, Pseudomonas aeruginosa ATCC 27853 and Candida albicans ATCC 10231). The remaining 12 bacterial strains (Staphylococcus epidermidis, Enterococcus, Streptococcus pyogenes, Streptococcus agalactiae, Streptococcus pneumoniae, Haemophilus influenzae, Proteus mirabilis, Salmonella enteritidis, Corynebacterium spp., Salmonella enteritidis, Shigella flexneri, Campylobacter jejuni and Acinetobacter spp.) were clinical isolates provided from the Institute of Microbiology and Parasitology, Faculty of Medicine, Skopje, R. Macedonia.

A nutrient (Mueller Hinton) agar (Merck, Darmstadt, Germany), blood agar (Oxoid, Basingstoke, UK) and Sabouraud agar (bioMerieux, Durham, NC) were used for growing of the microbes.

\section{Disc diffusion method}

Disc diffusion method was used for screening the antimicrobial activity of all essential oils in order to determine the growth inhibition zones of studied microorganisms that occur around certain essential oil. In this regard, microorganisms were suspended in sterile broth with turbidity corresponding to 0.5 and $1 \mathrm{Mc}$ Farland (approximate by $10^{7}-$ $10^{8} \mathrm{CFU} / \mathrm{ml}$ ) for all bacteria and for Candida albicans, respectively. The microbial suspensions were streaked over the surface of the agar media using a sterile cotton swabs to ensure uniform inoculation. After inoculation of microorganisms, discs of $6 \mathrm{~mm}$ in diameter were made at wellspaced intervals. They were filled with $85 \mu \mathrm{l}$ of $50 \%$ solutions of essential oils in dimethylsulfoxide (DMSO, Sigma-Aldrich, Germany) and one disc was filled only with
DMSO as a control. The plates were incubated at $37{ }^{\circ} \mathrm{C}$, aerobically for 24 hours. The growth inhibition zones were measured after incubation of the isolates under their optimal growth conditions and were ranged between $6 \mathrm{~mm}$ and $30 \mathrm{~mm}$ in diameter. The antimicrobial activity was determined according to the diameters of the inhibition zones (0-14 mm resistant - $\mathrm{R}, 14-19 \mathrm{~mm}$ moderate susceptible $\mathrm{M}$ and 19-30 susceptible - $\mathrm{S}$ microorganisms).

\section{Broth dilution method}

This method was used in order to determine minimal inhibitory concentration (MIC) of the particular essential oil prepared as 50\% solution in DMSO). For that purposes, $25 \mu \mathrm{l}$ of those essential oils were diluted in equal quantities of $0.9 \%$ sodium chloride solution, to make them with the concentration of $25 \%$. This concentration was decreased five times, subsequently, by adding $25 \mu \mathrm{l}$ of each bacterial or fungal suspension, thus the final concentrations were: $12.5 \%, 6.2 \%, 3.1 \%, 1.5 \%$ and $0.7 \%$ or $125 \mu \mathrm{l} / \mathrm{ml}, 62 \mu \mathrm{l} / \mathrm{ml}$, $31 \mu \mathrm{l} / \mathrm{ml}, 15 \mu \mathrm{l} / \mathrm{ml}$ and $7 \mu \mathrm{l} / \mathrm{ml}$, respectively. $15 \mu \mathrm{l}$ of each bacterial or fungal suspensions with these particular concentrations were inoculated on solid media (Miller-Hinton agar, blood agar, Sabouraud agar), depending on the type of microorganism. The growth of any microorganism was evaluated after its incubation under the optimal growth conditions. The lowest concentration of essential oil which was able to inhibit the growth of the particular microorganism was considered as its minimal inhibitory concentration (MIC).

\section{Results and discussion}

The yields of the leaves essential oil were: $7.3,7.3$ and $9.0 \mathrm{ml} / \mathrm{kg}$ for $\mathrm{JcS} / 10, \mathrm{JcB} / 11$ and $\mathrm{JcG} / 11$ respectively. Percentage presence with Kovat's retention indices of ninety identified components representing 86.07-93.31\% of the oil are presented in Table 2. Data analysis of the chemical composition revealed four main classes of components: monoterpene hydrocarbons $(\mathrm{MH})$, oxygen-containing monoterpenes (OM), sesquiterpene hydrocarbons (SH) and oxygen-containing sesquiterpenes (OS). Diterpenes (D) were present in small amounts as well as some non-terpene components (NT). Monoterpene hydrocarbons were the most abundant fraction in all investigated oils $(39.97 \%, 52.32 \%$ and $53.39 \%$, for the samples from Shara Mtn., Galicica Mtn. and Bistra Mtn., respectively), followed by SH $(28.64 \%, 20.66 \%$ and $12.27 \%$, respectively) (Table 2). Oxygen-containing monoterpenes were present in much smaller amounts $3.89 \%$ in samples from Shara Mtn., 6.69\% in samples from Galicica Mtn. and 12.16\% in samples from Bistra Mtn.) as well as the oxygen-containing sesquiterpenes $(13.57 \%, 11.53 \%$ and $5.98 \%$, respectively). The ratios between monoterpenes (M) and sesquiterpenes (S) were 1:1, 2:1 and 3:1 for LEO from Shara Mtn., Galicica Mtn. and Bistra Mtn., respectively (Fig. 1). 


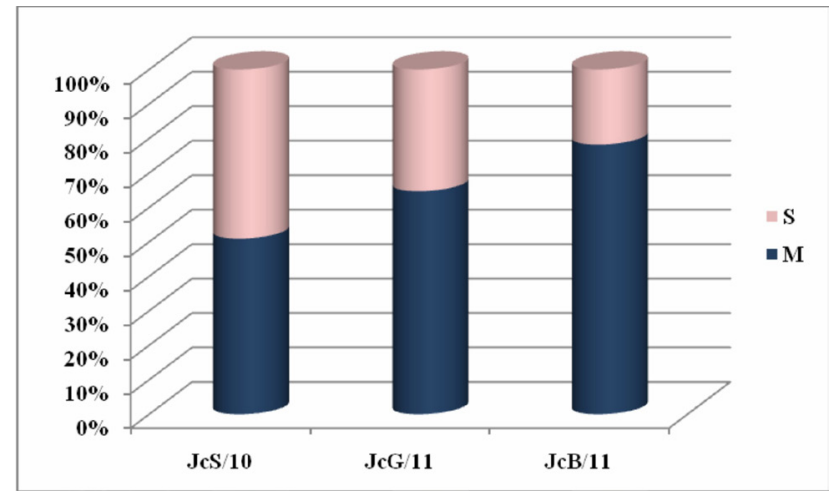

Fig. 1. The monoterpenes $(\mathrm{M}) /$ sesquiterpenes $(\mathrm{S})$ ratio of leaves essential oil from Macedonian juniper

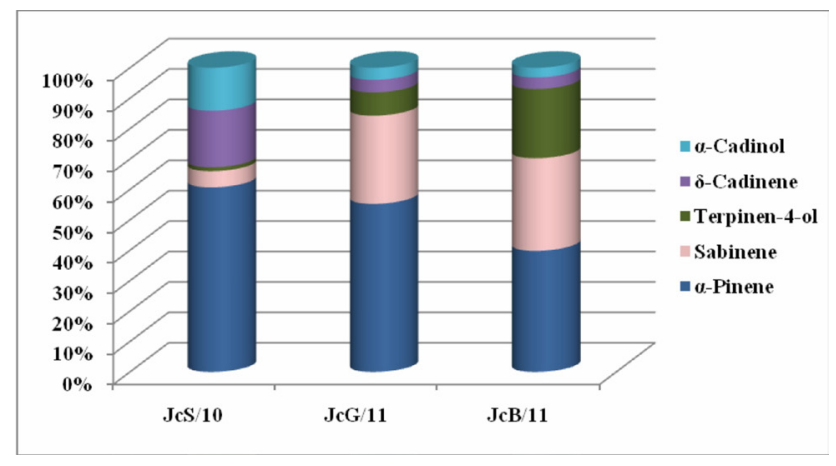

Fig. 2. Predominant components in the leaves essential oil from wild growing $J$. communis in R. Macedonia

GC/FID/MS analysis of the juniper leaves essential oil showed presence of two main components in the samples from Galicica Mtn. and Bistra Mtn.: $\alpha$-pinene (28.68\% and $21.27 \%$, respectively) and sabinene (15.5\% and $16.27 \%$, respectively). Additionally, limonene was identified with $2.82 \%$ and $6.95 \%$, respectively, while terpinene-4-ol was the most abundant oxygen-containing monoterpenes (3.98\% and $12.16 \%$, respectively). Concerning the sesquiterpene fraction, $\beta$-elemene, trans-(E)-caryophyllene, $\alpha$-humulene, germacrene $\mathrm{D}, \delta$-cadinene and $\alpha$-cadinol were present in amounts between 1.37 and 3.45\%. Likewise LEO from Shara Mtn. contained $\alpha$-pinene (26.05\%) as predominant component, followed by smaller amounts of $\delta$-3-carene $(3.15 \%), \beta$-phellandrene $(4.37 \%)$ and sabinene $(2.29 \%)$. Terpinene-4-ol was present with $0.55 \%$. The sesquiterpene components ( $\beta$-elemene, $\delta$-cadinene and $\alpha$ cadinol) were present in amounts up to $7.98 \%$. Evaluation of the occurrence of the main components that characterized the leaves essential oil of Macedonian juniper (Fig.2), showed that sabinene was found in Bistra Mtn. and Galicica Mtn., terpinen-4-ol only in Bistra Mtn., while the sesquiterpenes, $\delta$-cadinene and $\alpha$-cadinol were characteristic for the LEO from Shara Mtn.
Similarity in the composition of the leaves essential oil was found with the Greek $J$. communis where $\alpha$-pinene $(41.25 \%)$ and sabinene $(17.4 \%)$ have been predominant constituents followed by smaller amounts of limonene $(4.2 \%)$, terpinen-4-ol $(2.7 \%), \beta$-myrcene $(2.6 \%)$ and $\beta$-pinene (2.0\%) (Chatzopoulou et al., 1993). Further, the Estonian $J$. communis LEO has been also rich in $\alpha$-pinene (33.3-45.6\%) and sabinene (0.2-15.4\%) while limonene, trans-(E)-caryophyllene, $\alpha$-humulene and germacrene D were present in smaller amounts (Orav et al., 2010a, 2010b). Raal et al. (2010) reported similar composition for the essential oil obtained from branches of $J$. communis from Estonia comparing to the leaves essential oil where $\alpha$-pinene (40.4-62\%) and limonene (4.2-10\%) were dominant components, followed by $\alpha$-cadinol, $\delta$-cadinene, $\gamma$ muurolene and germacrene. LEO from $J$. communis from Lithuania was rich in $\alpha$-pinene (38.5-59.9\%), accompanied by $\beta$-phellandrene (4.1-11.4\%) or $\alpha$-cadinol (one sample of tested essential oil contained 8.7\%) (Butkine et al., 2005). Butkine et al. (2005) have identified 143 components in the juniper LEO which were divided in two groups according to the monoterpenes/sesquiterpenes ratio: $\mathrm{M}: \mathrm{S}=5: 1$ and $\mathrm{M}: \mathrm{S}=2: 1$. Filipowicz et al. (2009) have reported that populations of $J$. communis from Northern Poland have essential oils with different $\alpha$-pinene/sabinene ratio. Iranian authors found that juniper leaves essential oil was rich in sabinene $(40.7 \%)$, than $\alpha$-pinene $(12.5 \%)$ and terpinen-4-ol $(12.3 \%)$ (Shahmir et al., 2003). Asili et al. (2008), confirmed $\alpha$-pinene as predominant component in the Iranian $J$. communis subsp. hemisphaerica LEO, while Ottavioli et al. (2009) for French J. communis subsp. alpina reported limonene (9.2-53.9\%), $\beta$-phellandrene (3.7-25.2\%), $\alpha$-pinene (1.4-33.7\%) and sabinene (0.1-33.6\%) as major constituents. The LEO from Indian J. communis contained predominantly sabinene $(22.8 \%), \beta$-pinene $(10.7 \%)$, transsabinene hydrate $(6.0 \%)$ and $\gamma$-cadinene $(10.6 \%)$ (Kumar et al., 2007).

\section{Antimicrobial activity}

Antimicrobial screening of the essential oils was made by disc diffusion and broth dilution method against 16 bacterial isolates of Gram positive and Gram negative bacteria and one strain of Candida albicans (Table 3). The highest MIC $(125 \mu \mathrm{l} / \mathrm{ml})$ of LEOs were towards Staphylococcus aureus and Streptococcus pyogenes, and moderate antimicrobial activity against Streptococcus agalactiae, Haemophillus influnzae, Corynebacterium spp. and Campylobacter jejuni (MIC > $500 \mu \mathrm{l} / \mathrm{ml})$. Candida albicans, Staphylococcus epidermidis, Acinetobacter spp., Salmonella enteritidis, Shigella flexneri, Klebsiella pneumonia, Pseudomonas aeruginosa and Proteus mirabilis were completely resistant to the antimicrobial activity of juniper oil.

Antimicrobial activity of juniper essential oils was previously investigated so the available literature pointed out no activity to some antimicrobial effects against vari- 
Table 2. The chemical composition of the leaves essential oil (LEO) of Juniperus communis from R. Macedonia

\begin{tabular}{|c|c|c|c|c|c|c|}
\hline No. & Components & KIL & KIE & $\mathrm{JcS} / 10$ & $\mathrm{JcG} / 11$ & $\mathrm{JcB} / 11$ \\
\hline 1 & Tricyclene & 921 & 930.5 & - & 0.04 & - \\
\hline 2 & $\alpha$-Thujene & 924 & 933.3 & - & 0.79 & 2.43 \\
\hline 3 & $\alpha$-Pinene & 932 & 937.5 & 26.05 & 28.68 & 21.27 \\
\hline 4 & Camphene & 946 & 946.3 & 0.18 & 0.91 & - \\
\hline 5 & n-Heptanol & 959 & 946.5 & - & - & 5.69 \\
\hline 6 & Sabinene & 969 & 962.6 & 2.29 & 15.05 & 16.27 \\
\hline 7 & $\beta$-Pinene & 974 & 964.2 & 2.28 & $\operatorname{tr}$ & - \\
\hline 8 & $\beta$-Myrcene & 988 & 975.7 & 0.55 & 1.69 & 2.12 \\
\hline 9 & $\delta$-2-Carene & 1001 & 982.1 & 0.16 & 0.17 & - \\
\hline 10 & $\alpha$-Phellandrene & 1002 & 995.2 & 0.38 & - & - \\
\hline 11 & $\delta$-3-Carene & 1008 & 989.7 & 3.15 & 0.22 & - \\
\hline 12 & $\alpha$-Terpinene & 1014 & 995.3 & - & 0.12 & - \\
\hline 13 & $p$-Cymene & 1020 & 1002 & 0.56 & 1.43 & $\operatorname{tr}$ \\
\hline 14 & $o$-Cymene & 1022 & 1003 & - & - & 4.35 \\
\hline 15 & Limonene & 1024 & 1005 & - & 2.82 & 6.95 \\
\hline 16 & $\beta$-Phellandrene & 1025 & 1016 & 4.37 & - & - \\
\hline 17 & $\gamma$-Terpinene & 1054 & 1033 & - & 0.23 & - \\
\hline 18 & Terpinolene & 1086 & 1062 & - & 0.21 & - \\
\hline 19 & Isopentyl 2-methylbutanoate & 1100 & 1083 & - & 0.1 & - \\
\hline 20 & $\alpha$-Campholenal & 1122 & 1102 & - & 0.16 & - \\
\hline 21 & trans-Pinocarveol & 1135 & 1118 & 0.47 & 0.18 & - \\
\hline 22 & trans-Verbenol & 1140 & 1128 & 1.16 & 0.37 & - \\
\hline 23 & 3-methyl-2-butenyl 3-methyl-Butanoate & 1147 & 1138 & - & 0.02 & - \\
\hline 24 & Borneol & 1165 & 1150 & 0.28 & 0.09 & - \\
\hline 25 & Terpinen-4-ol & 1174 & 1161 & 0.55 & 3.96 & 12.16 \\
\hline 26 & p-Cymene-8-ol & 1179 & 1170 & - & 0.24 & - \\
\hline 27 & $\alpha$-Terpineol & 1186 & 1174 & 0.37 & 0.33 & - \\
\hline 28 & Myrtenol & 1194 & 1178 & - & 0.29 & - \\
\hline 29 & Verbenone & 1204 & 1187 & $\operatorname{tr}$ & 0.27 & - \\
\hline 30 & trans-Carveol & 1215 & 1195 & - & 0.08 & - \\
\hline 31 & $\beta$-Citronellol & 1223 & 1205 & - & 0.1 & - \\
\hline 32 & Thymol methyl ether & 1232 & 1210 & - & 0.05 & - \\
\hline 33 & cis-Myrtanol & 1249 & 1248 & 0.15 & - & - \\
\hline 34 & Bornyl acetate & 1284 & 1260 & 0.78 & 0.42 & - \\
\hline 35 & trans-Sabinyl acetate & 1289 & 1280 & 0.13 & - & - \\
\hline 36 & Terpinen-7-al & 1290 & 1268 & - & 0.03 & - \\
\hline 37 & $\delta$-Elemene & 1335 & 1305 & 0.14 & 0.07 & - \\
\hline 38 & $\alpha$-Cubebene & 1345 & 1319 & 0.12 & 0.09 & - \\
\hline 39 & $\alpha$-Ylangene & 1373 & 1341 & - & 0.04 & - \\
\hline 40 & $\alpha$-Copaene & 1374 & 1345 & - & 0.62 & 0.67 \\
\hline 41 & $\beta$-Bourbonene & 1387 & 1354 & - & 0.32 & - \\
\hline 42 & $\beta$-Elemene & 1389 & 1362 & 4.17 & 2.62 & 1.37 \\
\hline 43 & Sibirene & 1400 & 1384 & 2.31 & 0.39 & 0.31 \\
\hline 44 & 2-epi-Funebrene & 1411 & 1394 & 0.08 & - & - \\
\hline
\end{tabular}




\begin{tabular}{|c|c|c|c|c|c|c|}
\hline No. & Components & KIL & KIE & $\mathrm{JcS} / 10$ & $\mathrm{JcG} / 11$ & $\mathrm{JcB} / 11$ \\
\hline 45 & trans-(E)-Caryophyllene & 1417 & 1387 & 0.81 & 3.45 & 1.52 \\
\hline 46 & $\beta$-Copaene & 1430 & 1396 & 0.13 & 0.2 & - \\
\hline 47 & $\gamma$-Elemene & 1434 & 1400 & 2.95 & 0.58 & 0.67 \\
\hline 48 & Sesquterpene ${ }^{* 1}$ & / & 1405 & - & 0.04 & - \\
\hline 49 & Sesquterpene ${ }^{* 2}$ & / & 1411 & - & 0.11 & - \\
\hline 50 & trans-Muurola-3,5-diene & 1451 & 1418 & 0.1 & $\operatorname{tr}$ & - \\
\hline 51 & $\alpha$-Humulene & 1452 & 1421 & 1.07 & 2.89 & 1.37 \\
\hline 52 & cis-Muurola-4(14),5-diene & 1465 & 1431 & 0.26 & 0.21 & - \\
\hline 53 & Germacrene D & 1484 & 1450 & 2.45 & 3.23 & 1.43 \\
\hline 54 & $\beta$-Selinene & 1489 & 1455 & 0.1 & 0.53 & 0.64 \\
\hline 55 & $\alpha$-Selinene & 1498 & 1463 & 1.07 & 0.88 & 0.7 \\
\hline 56 & $\alpha$-Muurolene & 1500 & 1468 & 1.32 & 0.61 & 0.45 \\
\hline 57 & $\delta$-Amorphene & 1511 & 1487 & 0.21 & - & - \\
\hline 58 & $\gamma$-Cadinene & 1513 & 1481 & 2.26 & 0.9 & 0.6 \\
\hline 59 & $\delta$-Cadinene & 1522 & 1490 & 7.98 & 2.15 & 2.05 \\
\hline 60 & trans-Cadina-1.4-diene & 1533 & 1498 & 0.31 & 0.1 & - \\
\hline 61 & $\alpha$-Cadinene & 1537 & 1517 & 0.5 & - & - \\
\hline 62 & $\alpha$-Calacorene & 1544 & 1510 & 0.2 & 0.22 & - \\
\hline 63 & Elemol & 1548 & 1516 & 0.31 & 0.16 & - \\
\hline 64 & Germacrene B & 1559 & 1525 & - & 0.41 & 0.49 \\
\hline 65 & Nerolidol E & 1561 & 1528 & - & 0.5 & - \\
\hline 66 & Germacrene D-4-ol & 1574 & 1544 & - & $\operatorname{tr}$ & - \\
\hline 67 & Spathulenol & 1577 & 1546 & - & 1.67 & 1.06 \\
\hline 68 & Caryophyllene oxide & 1582 & 1552 & - & 1.73 & 0.78 \\
\hline 69 & Viridiflorol & 1592 & 1563 & - & 0.29 & - \\
\hline 70 & Humulene epoxide II & 1608 & 1578 & 0.77 & 1.17 & 0.71 \\
\hline 71 & 1,10-di-epi 1-epi-Cubenol & 1618 & 1582 & $\operatorname{tr}$ & $\operatorname{tr}$ & - \\
\hline 72 & 1-epi-Cubenol & 1627 & 1595 & 2.31 & 0.51 & 0.39 \\
\hline 73 & $\tau$-Murolol (epi- $\alpha$-Muurolol) & 1640 & 1609 & 4.13 & 1.32 & 1.07 \\
\hline 74 & $\alpha$-Muurolol & 1644 & 1613 & - & 0.44 & 0.3 \\
\hline 75 & $\alpha$-Cadinol & 1652 & 1622 & 6.05 & 2.04 & 1.67 \\
\hline 76 & Cadalene & 1675 & 1624 & - & $\operatorname{tr}$ & - \\
\hline 77 & Sesquterpene ${ }^{* 3}$ & / & 1654 & - & 0.34 & - \\
\hline 78 & Shyobunol & 1685 & 1659 & - & 0.31 & - \\
\hline 79 & 8-Cedren-13-ol & 1688 & 1676 & - & 0.26 & - \\
\hline 80 & Sesquterpene ${ }^{* 4}$ & / & 1690 & - & 0.21 & - \\
\hline 81 & Oplopanone & 1739 & 1705 & - & 0.23 & - \\
\hline 82 & Sesquterpene ${ }^{* 5}$ & / & 1778 & - & 0.23 & - \\
\hline 83 & (Z)-Lanceol & 1760 & 1790 & - & 0.12 & - \\
\hline 84 & Pimaradiene & 1948 & 1934 & - & 0.06 & - \\
\hline 85 & Manool oxide & 1987 & 1962 & - & 0.27 & - \\
\hline 86 & Abietatriene & 2055 & 2025 & - & 0.62 & 0.32 \\
\hline 87 & Abietadiene & 2087 & 2052 & - & 0.12 & - \\
\hline 88 & dehydro-Abietal & 2274 & 2238 & - & 0.03 & - \\
\hline 89 & Abietal & 2313 & 2278 & - & 0.04 & - \\
\hline
\end{tabular}




\begin{tabular}{clccccc}
\hline \hline No. & Components & KIL & KIE & JcS/10 & JcG/11 & JcB/11 \\
\hline 90 & Octacosane & 2800 & 2822 & - & 0.93 & - \\
& & & & & & \\
& Non-terpene components (NT) & & & - & 0.97 & 5.69 \\
& Monoterpene hydrocarbons (MH) & & 39.97 & 52.32 & 53.39 \\
& Oxygen-containing monoterpenes (OM) & & 3.89 & 6.69 & 12.16 \\
& Sesquiterpene hydrocarbons (SH) & & 28.64 & 20.66 & 12.27 \\
& Oxygen-containing sesquiterpenes (OS) & & 13.57 & 11.53 & 5.98 \\
& Diterpenes (D) & & - & 1.14 & 0.32 \\
& Total (\%) & & 86.07 & 93.31 & 89.81 \\
\hline
\end{tabular}

KIL - Kovat's (retention) index - literature data (Adams, 2007); KIE - Kovat's (retention) index experimentally determined (AMDIS); (-) - not found, $\operatorname{tr}$ - traces $<0.02,{ }^{{ }^{1}, 2,3,4,5}$ - tentative identification.

Table 3. Antimicrobial activity of the leaves essential oil of Juniperus communis

\begin{tabular}{|c|c|c|c|c|c|}
\hline No. & Microorganism & & $\mathrm{JcS} / 10$ & $\mathrm{JcG} / 11$ & $\mathrm{JcB} / 11$ \\
\hline \multirow{2}{*}{1} & \multirow{2}{*}{ Streptococcus pneumoniae } & DD & $\mathrm{R}$ & $\mathrm{R}$ & $\mathrm{R}$ \\
\hline & & MIC & n.m. & n.m. & n.m. \\
\hline \multirow{2}{*}{2} & \multirow{2}{*}{ Staphylococcus aureus } & DD & $\mathrm{S}$ & $\mathrm{S}$ & $\mathrm{S}$ \\
\hline & & MIC & 125 & 125 & 125 \\
\hline \multirow{2}{*}{3} & \multirow{2}{*}{ Staphylococcus epidermidis } & DD & $\mathrm{R}$ & $\mathrm{R}$ & $\mathrm{R}$ \\
\hline & & MIC & n.m. & n.m. & n.m. \\
\hline \multirow{2}{*}{4} & \multirow{2}{*}{ Streptococcus agalactiae } & DD & M & $\mathrm{R}$ & $\mathrm{R}$ \\
\hline & & MIC & $>500$ & n.m. & n.m. \\
\hline \multirow{2}{*}{5} & \multirow{2}{*}{ Streptococcus pyogenes } & DD & $\mathrm{S}$ & M & M \\
\hline & & MIC & 125 & $>500$ & $>500$ \\
\hline \multirow{2}{*}{6} & \multirow{2}{*}{ Enterococcus } & $\mathrm{DD}$ & $\mathrm{R}$ & $\mathrm{R}$ & $\mathrm{R}$ \\
\hline & & MIC & n.m. & n.m. & n.m. \\
\hline \multirow{2}{*}{7} & \multirow{2}{*}{ Corynebacterium spp. } & DD & $\mathrm{M}$ & $\mathrm{R}$ & $\mathrm{R}$ \\
\hline & & MIC & $>500$ & n.m. & n.m. \\
\hline \multirow{2}{*}{8} & \multirow{2}{*}{ Haemophilus influenzae } & DD & $\mathrm{M}$ & $\mathrm{M}$ & M \\
\hline & & MIC & $>500$ & $>500$ & $>500$ \\
\hline \multirow{2}{*}{9} & \multirow{2}{*}{ Acinetobacter spp. } & DD & $\mathrm{R}$ & $\mathrm{R}$ & $\mathrm{R}$ \\
\hline & & MIC & n.m. & n.m. & n.m. \\
\hline \multirow{2}{*}{10} & \multirow{2}{*}{ Escherichia coli } & $\mathrm{DD}$ & $\mathrm{R}$ & $\mathrm{R}$ & $\mathrm{R}$ \\
\hline & & MIC & n.m. & n.m. & n.m. \\
\hline \multirow{2}{*}{11} & \multirow{2}{*}{ Salmonella enteritidis } & DD & $\mathrm{R}$ & $\mathrm{R}$ & $\mathrm{R}$ \\
\hline & & MIC & n.m. & n.m. & n.m. \\
\hline \multirow{2}{*}{12} & \multirow{2}{*}{ Shigella flexneri } & $\mathrm{DD}$ & $\mathrm{R}$ & $\mathrm{R}$ & $\mathrm{R}$ \\
\hline & & MIC & n.m. & n.m. & n.m. \\
\hline \multirow{2}{*}{13} & \multirow{2}{*}{ Campylobacter jejuni } & $\mathrm{DD}$ & M & M & $\mathrm{M}$ \\
\hline & & MIC & $>500$ & $>500$ & $>500$ \\
\hline \multirow{2}{*}{14} & \multirow{2}{*}{ Klebsiella pneumoniae } & DD & $\mathrm{R}$ & $\mathrm{R}$ & $\mathrm{R}$ \\
\hline & & MIC & n.m. & n.m. & n.m. \\
\hline \multirow{2}{*}{15} & Pseudomonas aеruoinos & DD & $\mathrm{R}$ & $\mathrm{R}$ & $\mathrm{R}$ \\
\hline & Pseudomonas aeruginosa & MIC & n.m. & n.m. & n.m. \\
\hline 16 & Proteus mirahilis & $\mathrm{DD}$ & $\mathrm{R}$ & $\mathrm{R}$ & $\mathrm{R}$ \\
\hline 10 & Proteus mirabilis & MIC & n.m. & n.m. & n.m. \\
\hline & & DD & $\mathrm{R}$ & $\mathrm{R}$ & $\mathrm{R}$ \\
\hline 17 & Candida albicans & MIC & n.m. & n.m. & n.m. \\
\hline
\end{tabular}

DD - Disc diffusion (zone of inhibition including the diameter of disc $6 \mathrm{~mm}$ ), R - resistant with zone of inhibition 0 - 14 mm, M - moderate susceptible with zone of inhibition 14 - $19 \mathrm{~mm}$ and S - susceptible microorganism with zone of inhibition 19 - $30 \mathrm{~mm}$ ); MIC - minimum inhibitory concentration ( $\mu 1 /$ $\mathrm{ml}) ;$ n.m. - not measured. 
ous tested microbial strains. Essential oil (Juniperi aetheroleum) obtained from the juniper (J. communis) berries was evaluated for the antimicrobial activity against sixteen bacteria, seven yeast-like fungi, three yeasts and four dermatophyte strains. Juniper essential oil showed similar bactericidal activities against Gram-positive and Gram-negative bacterial strains, with MIC values between 8 and $70 \%$ $(\mathrm{V} / \mathrm{V})$, as well as a strong fungicidal activity against yeasts, yeast-like fungi and dermatophytes, with MIC values below $10 \%(\mathrm{~V} / \mathrm{V})$. The strongest fungicidal activity was recorded against Candida spp. (MIC from 0.78 to $2 \%, \mathrm{~V} / \mathrm{V}$ ) and dermatophytes (MIC from 0.39 to $2 \%, \mathrm{~V} / \mathrm{V}$ ). GC/MS analysis of the essential oil showed that predominant constituents in this oil were $\alpha$-pinene (29.17\%), $\beta$-pinene (17.84\%), sabinene $(13.55 \%)$, limonene $(5.52 \%)$ and $\beta$-myrcene $(0.33 \%)$ (Pepelnjak et al., 2005). The essential oil of $J$. communis growing wild in Kosovo, showed moderate to high activities against Staphylococcus aureus, Escherichia coli and Hafnia alvei, while Pseudomonas aeruginosa was resistant to the antimicrobial effects of the oil (Haziri et al., 2013). The leaves essential oils of $J$. communis subsp. hemisphaerica and $J$. oblonga from Iran did not show noticeable activity against Bacillus subtilis, Staphylococcus aureus, Escherichia coli, Pseudomonas aeruginosa and Candida albicans (Asili et al., 2008). Angioni et al. reported similar results concerning the antimicrobial activity of the essential oils from ripe and unripe berries and leaves of Italian $J$. communis against the most of the above mentioned microbial.

\section{Conclusion}

The essential oil (LEO) isolated from tree different leaves samples of wild growing Juniperus communis L. (Cupressaceae), from R. Macedonia was characterized with presence of $\alpha$-pinene $(21.37-28.68 \%)$ and sabinene (2.29-16.27\%), followed by limonene, terpinen-4-ol, $\beta$-elemene, trans $(\mathrm{E})$-caryophyllene, germacrene $\mathrm{D}$ and $\delta$ cadinene. Antimicrobial screening of the LEOs against 16 bacterial isolates of Gram positive and Gram negative bacteria and one strain of Candida albicans, showed the strongest antimicrobial activity towards Staphylococcus aureus and Streptococcus pyogenes (MIC $=125 \mu \mathrm{l} / \mathrm{ml}$ ) and moderate antimicrobial activity against Streptococcus agalactiae, Haemophillus influnzae, Corynebacterium spp. and Campylobacter jejuni (MIC > $500 \mu \mathrm{l} / \mathrm{ml})$. On the other hand, Candida albicans, Staphylococcus epidermidis, Acinetobacter spp., Salmonella enteritidis, Shigella flexneri, Klebsiella pneumonia, Pseudomonas aeruginosa and Proteus mirabilis were completely resistant to the antimicrobial effects of $J$. communis LEO.

\section{References}

Adams, R., 2007. Identification of essential oil components by gas chromatography/mass spectrometry. 4th Ed. Illinois: Allured Publishing Corporation.
Angioni, A., Barra, A., Russo, M.T., Coroneo, V., Dessi, S., Cabras, P., 2003. Chemical composition of the essential oils of Juniperus from ripe and unripe berries and leaves and their antimicrobial activity. J. Agric. Food Chem. 51 (10), 3073-3078.

Asili, J., Emami, S.A., Rahimizadeh, M., Fazly-Bazzaz, B.S., Hassanzadeh, M.K., 2008. Chemical and antimicrobial studies of Juniperus communis subsp. hemisphaerica and Juniperus oblonga essential oils. J. Essent. Oil Bear. Pl. 11 (1), 96-105.

Butkienë, R., Nivinskienë, O., Mockutë, D., 2005. $\alpha$-Pinene chemotype of leaf (needle) essential oils of Juniperus communis L. growing wild in Vilnius district. Chemija. 16 (1), 53-60.

Chatzopoulou, P.S., Katsiotis, S.T., 1993. Chemical investigation of the leaf oil of Juniperus communis L. J. Essent. Oil Res. 5 (6), 603-607.

Filipowicz, N., Madanecki, P., Gołębiowski, M., Stepnowski, P., Ochocka, R.J., 2009. HS-SPME/GC analysis reveals the population variability of terpene contents in Juniperus communis needles. Chem. Biodiv. 6 (12), 2290-2301.

Haziri, A., Faiku, F., Mehmeti, A., Govori, S., Abazi, S., Daci, M., Haziri, I., Bytyqi-Damoni A., Mele, L., 2013. Antimicrobial properties of the essential oil of Juniperus communis (L.) growing wild in east part of Kosovo. Am. J. Pharm. Toxicol. 8 (3), 128-133.

Koukos, P.K., Papadopoulou, K.I., 1997. Essential oil of Juniperus communis L. grown in northern Greece: variations of fruit oil yield and composition. J. Essent. Oil Res. 9 (1), 35-39.

Kumar, A., Yadav, L.B.S., Ahmad, J., Dubey, N., Puri, S., 2007. Chemical composition of commercial Juniperus communis L. leaf oil. J. Essent. Oil Bear. P1. 10 (4), 310-313.

Micevski, K., 1998. Flora na R. Makedonija. 1st Ed. Skopje: Makedonska akademija na naukite i umetnostite.

Orav, A., Kailas, T., Müürisepp, M., 2010a. Chemical investigation of the essential oil from berries and needles of common juniper (Juniperus communis L.) growing wild in Estonia. Nat. Prod. Res. 24 (19), 1789-1799b.

Orav, A., Koel, M., Kailas, T., Müürisepp, M., 2010b. Comparative analysis of the composition of essential oils and supercritical carbon dioxide extracts from the berries and needles of Estonian juniper (Juniperus communis L.). Procedia Chem. 2. 161-167.

Ottavioli, J., Gonny, M., Casanova, J., Bighelli, A., 2009. Chemical variability of the needle oil of Juniperus communis ssp. alpina from Corsica. Chem. Biodivers. 6 (12), 21922199.

Pepelnjak, S., Kosalec, I., Kalodzera, Z., Blazevic, N., 2005. Antimicrobial activity of juniper berry essential oil. Acta. Pharm. 55, 417-422.

Raal, A., Kanut, M., Orav, A., 2010. Annual Variation of yield and composition of the essential oil of Common Juniper (Juniperus communis L.) branches from Estonia. Balt. For. 16 (1), 50-56.

Shahmir, F., Ahmadi, L., Mirza, M., Korori, S.A.A., 2003. Secretory elements of needles and berries of Juniperus communis L. ssp. communis and its volatile constituents. Flavour Frag. J. 18 (5), 425-428.

Stassi, V., Verykokidou, E., Loukis, A., Harvala, A., Philianos, S., 1995. Essential Oil of Juniperus oxycedrus L. subsp. macrocarpa (Sm.) Ball. J. Essent. Oil Res. 7 (6), 675-676. 


\title{
Резиме
}

\section{Хемиски состав и антимикробната активност на етерично масло изолирано од листовите на Juniperus communis L. (Cupressaceae) од Република Македонија}

\author{
Флореша Села ${ }^{1}$, Марија Карапанџова ${ }^{1}$, Ѓ оше Стефков ${ }^{1}$, \\ Ивана Цветковиќ ${ }^{1 *}$, Елена Трајковска-Доќиќ ${ }^{2}$, Ана Кафтанџиева ${ }^{2}$, \\ Светлана Кулеванова ${ }^{1}$
}

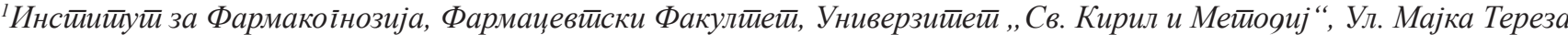
47, 1000 Скойје, Рейублика Макеоонија

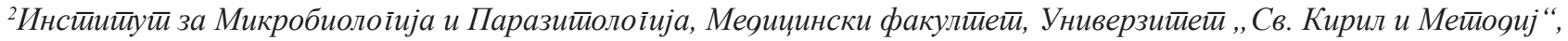
Ул. 50 Дивизија бр. 6, 1000 Скойје, Рейублика Макеоонија
\end{abstract}

Клучни зборови: Juniperus communis, етерично масло од листови, состав на масло, GC/FID/MS анализа, антимикробно дејство

Главна цел на студијата беше испитување на хемискиот состав и антимикробната активност на етеричното масло изолирано од листовите на три различни популации на диво растечки Juniperus communis L. ( Cupressaceae ) од Република Македонија. Приносот на дестилираните етерични масла се движи од 7.3 до $9.0 \mathrm{ml} / \mathrm{kg}$. Co GC/FID/MS анализа беа идентификувани вкупно деведесет компоненти што претставуваат 86.07-93.31 \% од маслото. Најзастапени компоненти во етеричното масло од листовите беа: $\alpha$-пинен ( $21.37-28.68$ \%) и сабинен ( $2.29-16.27$ \%), проследени со помали количества на лимонен, терпинен-4-ол, $\beta$-елемен, Е-кариофилен, гермакрен D и $\delta$-кадинен. Антимикробната активност на маслото беше определена со диск дифузиона и агар дилуциона метода на 16 бактериски изолати на грам позитивни и грам негативни бактерии и еден вид на Candida albicans. Две бактерии, Staphylococcus aureus и Streptococcus pyogenes беа чувствителни на маслото од смрека, со MIC=125 $\mu 1 / \mathrm{ml}$. Етеричното масло од листови покажа умерено антимикробно дејство против Streptococcus agalactiae, Haemophilus influnzae, Corynebacterium spp. и Campylobacter jejuni (MIC> 50 \%). Candida albicans, Staphylococcus epidermidis, Acinetobacter spp., Salmonella enteritidis, Shigella flexneri, Klebsiella pneumonia, Pseudomonas aeruginosa и Proteus mirabilis беа потполно резистентни на маслото изолирано од иглички на J. communis. 



\title{
Bioinspired bioartifical polymer hybrid composites for propolis vaginal delivery I: formulation development and optimization of gelling temperature using experimental design
}

\author{
Maja Simonoska-Crcarevska*, Ana Zafirovska-Gapkovska, Kristina Mladenovska, \\ Renata Slavevska Raicki, Nikola Geskovski, Simona Dimcevska, Marija Glavas-Dodov \\ Institute of pharmaceutical technology, Faculty of pharmacy, "Ss. Cyril \& Methodius" University, Majka Teresa 47, \\ Skopje, R. Macedonia \\ Center of pharmaceutical nanotechnology, Faculty of pharmacy, "Ss. Cyril \& Methodius" University, Majka Teresa 47, \\ Skopje, R. Macedonia
}

Received: April 2013; Accepted: June 2013

\begin{abstract}
Polymer hybrid composites for propolis vaginal delivery were developed and optimized in term of gelling temperature (Tg) using experimental design studies. Formulation of intelligent delivery system, with in situ gelling and controlled release properties, was carried out by bioartificial blending of chitosan and poloxamers, Lutrol ${ }^{\circledR} \mathrm{F} 127$ and Lutrol ${ }^{\circledR} \mathrm{F} 68$.

Response-surface, Box-Behnken, experimental design was applied for determination of key factors influencing $T g$. Influence of Lutrol ${ }^{\circledR}$ F127 concentration, Lutrol ${ }^{\circledR}$ F68/Lutrol ${ }^{\circledR}$ F127 mass ratio and volume of simulated vaginal fluid was evaluated. Derived correlations enabled formulation optimization in term of $\operatorname{Tg}\left(32^{\circ} \mathrm{C}\right)$. The model was cross-validated. Confirmation report and relative error percent of predicted and experimental values were obtained.
\end{abstract}

Key words: bioinspired polymer hybrid composites, propolis, vaginal delivery, experimental design

\section{Introduction}

Bacterial vaginosis and vulvovaginal candidiasis are the most common causes of vaginal infections and they are often referred as symptomatic vaginitis. Conventional approach encompasses use of antibiotics and antimycotics delivered in form of solutions, foams, tablets and pessasries as well as rings, creams and gels (Morlion, 2009). The choice of the most appropriate delivery system will depend on different considerations: required effect (local or systemic), drug release (immediate or controlled) and patient acceptability (Woolfson et al., 2007).

\footnotetext{
* e-mail: msimonoska@ff.ukim.edu.mk tel.: +38923126032 ; fax: +38923123054
}

Conventional vaginal drug delivery systems are associated with multiple days of dosing, dripping, leakage and messiness, causing discomfort to users and expulsion due to the self-cleansing action of the vaginal tract (Yenkar et al., 2013), hence leading to poor patient compliance and unfulfilled desired therapeutic efficacy. Having in mind previous, bioinspired vaginal delivery system should be developed thus offering the advantages of easy administration and spreading in the vagina, slow clearance from local sites allowing prolonged drug release at the desired site of action and hence resulting with better therapeutic efficacy. The rational approach would comprise bioartifical blending of natural and synthetic polymers conferring to unique structural and mechanical properties of the de- 
signed delivery system. By bioartificial blending the concept of biomimicry of several materials can be developed leading to new generation of intelligent vaginal delivery systems (Sionkowska, 2011). Efficient bioresponsive system for vaginal delivery could be formulated using thermo sensitive, $\mathrm{pH}$ responsive and/or ion activated polymer along with mucoadhesive polymers in order to accomplish the desired physico-chemical and biopharmaceutical properties required for efficacious and safe therapy.

One of the most commonly used thermosensitive materials are poloxamers i.e. polyethylene oxide - propylene oxide - polyethylene oxide block copolymers (PEO-PPOPEO) recognized under the proprietary name of Lutrol ${ }^{\circledR}$, especially Lutrol ${ }^{\circledR}$ F127 and Lutrol ${ }^{\circledR}$ F68 characterized by biocompatibility and good compatibility with various drugs and pharmaceutical excipients. The additional advantages are easy availability and simple method for gel preparation and drug loading (Koffi et al., 2006). Addition of bio/mucoadhesive macromolecules to the PEO-PPOPEO based delivery system would result with prolonged residence time along with sustained drug release at the site of action. Blending of PEO-PPO-PEO based polymer systems with other bio/mucoadhesive polymers would result in substantially improved bio/mucoadhesive properties and at the same time surmounting possible rapid gel erosion due to weak mechanical strength (Varshosaz et al., 2008; Yuan et al., 2012). Therefore chitosan is a promising adjuvant, especially due to its additional antimicrobial and antifungal activity (Peña et al., 2013; Tikhonov et al., 2006).

Having in mind that propolis biological and pharmacological properties as antimicrobial and antifungal agent are well known and documented (Sforcin and Bankova, 2011), propolis thermosensitive gel with bio/mucoadhesive properties was developed with rationale of efficacious treatment of vaginal infections. Experimental design studies were used for development and optimization of propolis vaginal delivery system with in situ gelling properties. Lutrol ${ }^{\circledR}$ F127, Lutrol ${ }^{\circledR}$ F68 and chitosan (low viscous, $95 \%$ deacetilation) were used for polymer hybrid composites with desired, thermoresponsive, bio/mucoadesive and prolonged local drug release features. Having in mind that in vivo, designed formulations will be subjected to the dilution with vaginal fluids, the volume of vaginal fluid (usually $\sim$ up to $0.75 \mathrm{ml}$ ) (Owen and Katz, 1999) was also considered as one of the parameters affecting their properties.

\section{Material and methods}

\section{Materials}

Chitosan (low viscous, 95\% deacetilation) (CTS) was obtained from Sigma-Aldrich, USA. Lutrol® ${ }^{\circledR} 127$ and Lutrol ${ }^{\circledR}$ F68 were purchased from BASF (Ludwigshaften, Germany). 20\% propylene-glycolic extract of propolis was kindly donated by Galafarm, Macedonia. All other chemicals were with analytical grade and used as received.

\section{Preparation of thermosensitive gels}

Cold method (Schmolka, 1972) with minor modification was used for preparation of in situ gels. Briefly, 1.5\% CTS solution was prepared by dissolving CTS powder in $1 \%$ lactic acid under gentle stirring (300 rpm). Afterwards, propylene-glycolic extract of propolis as active agent and hence, potassium sorbate as preservative were added. Various amounts of Lutrol ${ }^{\circledR}$ F127 and Lutrol ${ }^{\circledR}$ F 68 were added gradually under continuous agitation $(200 \mathrm{rpm})$ until total dissolution. Obtained viscous solutions were kept for $24 \mathrm{~h}$ at $4{ }^{\circ} \mathrm{C}$ to eliminate foam and air bubbles. The final concentration of propolis in prepared formulations was $3 \%(\mathrm{w} / \mathrm{w})$.

\section{Experimental design}

Response surface method (RSM) is empirical statistical technique that uses quantitative data derived from designed experiments in order to determine the regression pattern and working conditions (Alam et al., 2007; Garg et al., 2008; Ricou-Hoeffer et al., 2001; Tan et al., 2008). Graphical display of their dependence is called response surface and applying this approach, description of the individual and cumulative effects of the studied variables and their impact on appropriate responses could be done. The main objective of RSM is determining the optimal values of variables in order to obtain the desired values of responses (Myers and Montgomery, 1971). Application of statistical experimental design during the development of the formulation may reduce the variability of the procedure, the time of performing the experiments and the total cost, thus resulting with better overall results (Annadurai, 2000).

Response-surface, Box-Behnken design is an independent quadratic design where designed combinations are at the midpoints of edges of the deigned space and at the center. This design is rotatable and requires 3 levels of each factor. Compared to response surface, central composite design it requires fewer designed combinations in cases involving same number of factors. Its "missing corners" may be useful when the experimenter should avoid combined factor extremes thus preventing a potential loss of data in those cases (Chopra et al., 2007a). The quadratic-model could be described by the Eq. 1:

$$
\begin{aligned}
& Y=b_{\mathrm{o}}+b_{1} X_{1}+b_{2} X_{2}+b_{3} X_{3}+b_{12} X_{1} X_{2}+b_{13} X_{1} X_{3}+ \\
& b_{23} X_{2} X_{3}+b_{11} X_{1}^{2}+b_{22} X_{2}^{2}+b_{33} X_{3}^{2}
\end{aligned}
$$

where $\mathrm{Y}$ is the measured response associated with each factor level combination; $b_{0}$ is an intercept; $b_{1}$ to $b_{33}$ are regression coefficients computed from the observed experimental values of $Y$; and $X_{1}, X_{2}$ and $X_{3}$ are the coded levels of independent variables. The terms $\mathrm{X}_{1} \mathrm{X}_{2}$ and $\mathrm{X}^{2} \mathrm{i}(\mathrm{i}=1,2$ or 3 ) represent the interaction and quadratic terms, respectively (Box and Behnken, 1960; Chopra et al., 2007a; Chopra et al., 2007b).

Having in mind the previous, response-surface, BoxBehnken experimental design (Design Expert ${ }^{\circledR}$ V8; Stat- 
Design-Expert@ Software

Factor Coding: Actual

Geling Temperature

- Design points above predicted value

$\circ$ Design points below predicted value

$\square_{16}^{49}$

$\mathrm{X} 1=\mathrm{A}: \mathrm{F} 127$

$\mathrm{X} 2=\mathrm{B}: \mathrm{F} 68 / \mathrm{F} 127$

Actual Factor

C: Vaginal fluid $=0.38$

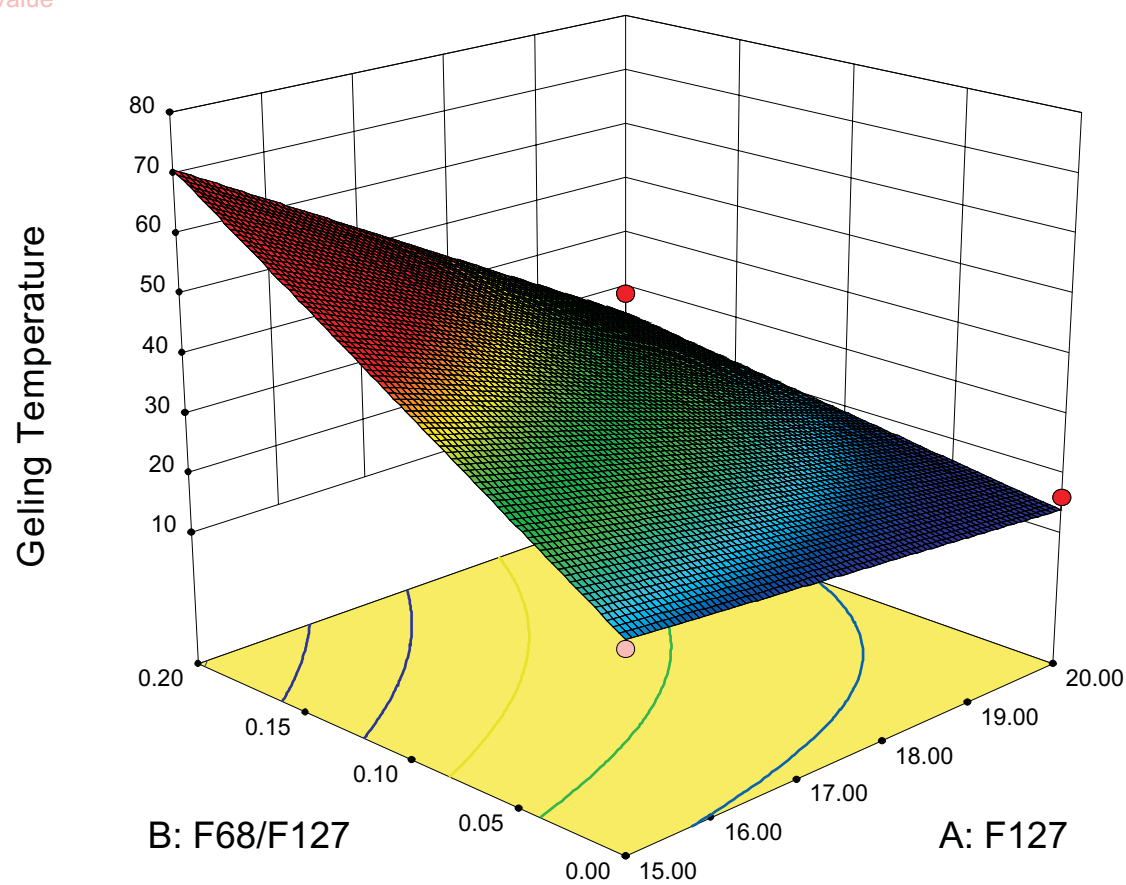

Fig.1. Estimated surface plots ilustrating the dependence of the response from selected model terms.

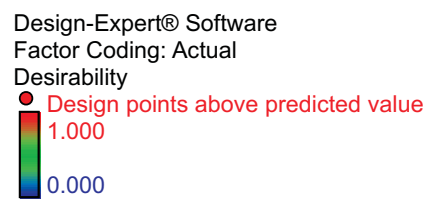

$\mathrm{X} 1=\mathrm{A}: \mathrm{F} 127$

$\mathrm{X} 2=\mathrm{B}: \mathrm{F} 68 / \mathrm{F} 127$

Actual Factor

C: Vaginal fluid $=0.75$

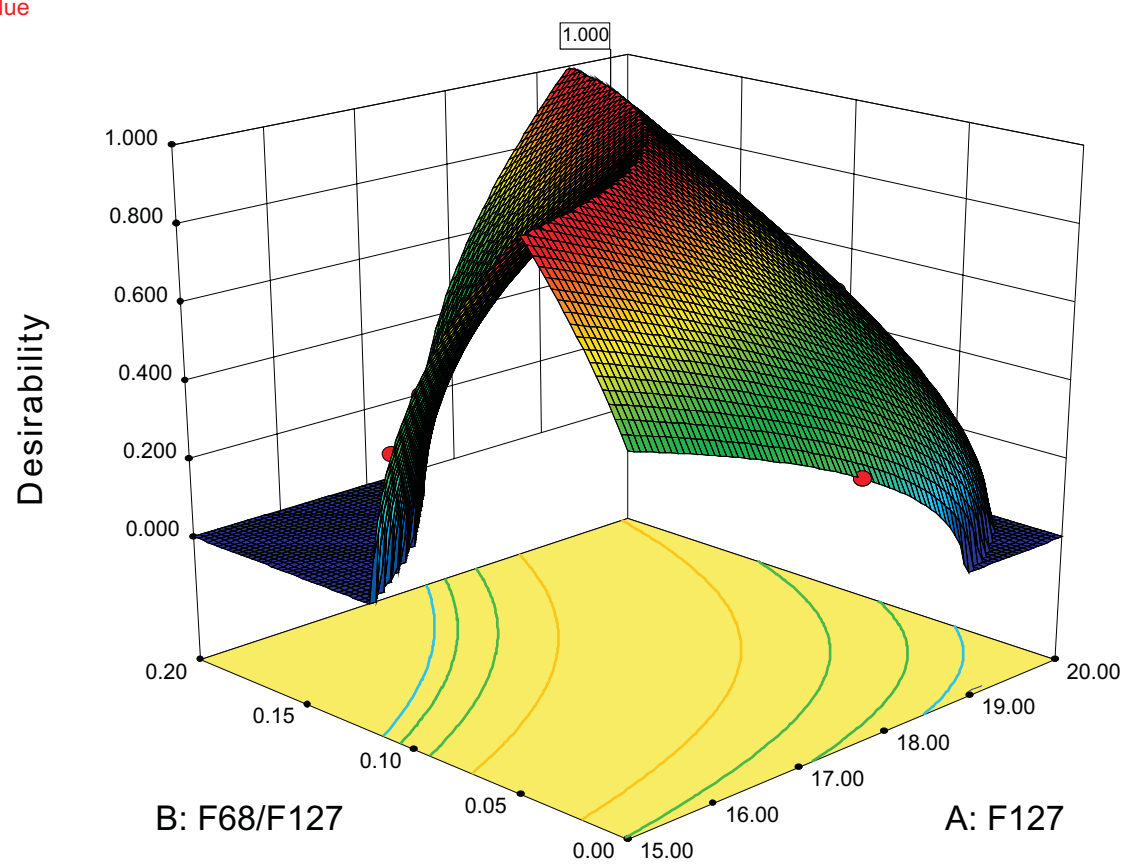

Fig. 2. Desirability graph for $T g$ response.

Макед. фарм. билт., 59 (1, 2) 33 - 40 (2013) 
Ease Inc., Minneapolis, MN) was applied for determination of the influence of concentration of Lutrol ${ }^{\circledR}$ F127 (factor A), Lutrol ${ }^{\circledR}$ F68/ Lutrol ${ }^{\circledR}$ F127 mass ratio (factor $\mathrm{B}$ ) and volume of simulated vaginal fluid (SVF) (factor C) upon the gelation temperature $(\mathrm{Tg})$ of the designed system with in situ gelling properties. The design matrix was constructed in one block where all factors were varied at $3 \mathrm{lev}-$ els, with 5 central points and the total of 17 experiments were carried out.

Low and high level values, coded and actual, of varied variables are presented in Table 1, while designed experiments are presented in Table 2. Experiments were carried out at random.

\section{Determination of gelation temperature (Tg)}

Gelation temperature $(\mathrm{Tg})$ of the designed formulations was determined using "Visual Tube Inversion Method" (Ur-Rehman et al., 2010) with minor modifications. Briefly, $2 \mathrm{ml}$ of prepared samples were placed in glass tubes, designated amount of SVF was added and tubes were put in a horizontal shaker water bath (50 strokes/ $\mathrm{min})$. The temperature of the water bath was gradually increased $\left(1{ }^{\circ} \mathrm{C} / \mathrm{min}\right)$ and the temperature at which the solution in the sample containing tube stopped flowing upon inverting the tube was recorded. Similarly, the temperature was decreased and the temperature, at which the gel started flowing, was recorded. The average of both temperatures was calculated as the critical $T g$.

\section{Results and discussion}

\section{Experimental design}

In the formulation development stage, response-surface, Box-Behnken, experimental design (Design Expert ${ }^{\circledR}$ V8; Stat-Ease Inc., Minneapolis, MN) was applied for determination of key factors affecting the $T g$ (Table 2) of the in situ mucoadhesive vaginal hydrogels. The concentration of Lutrol ${ }^{\circledR}$ F127 (15-20\%), Lutrol ${ }^{\circledR}$ F68/ Lutrol ${ }^{\circledR}$ F127 mass ratio (0-0.2) and the volume of SVF $(0-0.75 \mathrm{ml})$ were investigated as study variables and all factors were varied at 3 levels. 2FI model was suggested for describing the influence of variables upon the $T g$. ANOVA for response surface 2 FI model indicated that concentration of Lutrol ${ }^{\circledR}$ F127, Lutrol ${ }^{\circledR}$ F68/ Lutrol ${ }^{\circledR}$ F127 mass ratio and their interaction are significant model terms that goverend $T g$.

Estimated surface plots ilustrating the dependance of the $\mathrm{Tg}$ response from selected model terms is presneted on Fig.1

Final equation (Eq. 2) for $T g$ in terms of coded factors is:

$$
\begin{gathered}
\text { Geling Temperature }=+32.82-13.11 \cdot A+15.36 \cdot B \\
+0.25 \cdot C-9.6 \cdot A \cdot B-0.12 \cdot A \cdot C-0.12 \cdot B \cdot C(\text { Eq. } 2)
\end{gathered}
$$

Negative value of A indicated its inverse correlation influence on the followed response i.e. its increament would result with lower $T g$ while positive value of B suggested that by increasing the amount of Lutrol ${ }^{\circledR}$ F68 in the Lutrol ${ }^{\circledR}$ F68/ Lutrol ${ }^{\circledR}$ F127 ratio, the $T g$ would be higher. The positive correlation influence was determined for SVF influence. Interaction terms $(\mathrm{AB}, \mathrm{AC}$ and $\mathrm{BC})$ were found to have negative influence upon $T g$, where only $\mathrm{AB}$ interaction therm has significant $T g$ influence.

Albiet, $T g$ of specific polymer system depends on the molecules behaviour in the solution. Temperature-reversible polymer hybrid composites are consisted of molecule agregates physically juncted at specific polymer concetration and enviroment temperature, preceded by coiling of biopolymer chains and forming of double helices (Guenet, 1992). As, Lutrol ${ }^{\circledR} 668$ and Lutrol ${ }^{\circledR} F 127$ are three block copolymers consisted of hydrophilic PEO and hydrophobic PPO blocks at given concentration and temperature, molecules self association occurs and most likely driving force for gel formation is creation of micelles ordering into lattices. Presumably, PPO blocks are forming hydrophobic central core while PEO blocks are part of hydrophilic outer shell, thus interacting very strongly with itself and forming temporary crosslinks trough hydrophobic interaction, van-der Waals and hydrogen bonding (Bromberg and Ron, 1998; Escobar-Chávez et al., 2006). The observation for inverse relation of $T g$ with concentration of Lutrol ${ }^{\circledR}$ F127 are in accordance with literature data about stability regions of ordered micelle strucutres of Lutrol $\mathbb{R}$ and especially cubic three-dimensional lattices (gels) that moves towered lower temperatures at higher concentration (Bromberg and Ron, 1998) i.e. higher concentration would result with micelles packaging at lower temperatures.

Obtained results for $T g$ (Table 2) were in favor of the rationale behind Lutrol ${ }^{\circledR}$ F127 and Lutrol ${ }^{\circledR}$ F68 blending that resulted in $T g$ modulation. The findings about influence of Lutrol ${ }^{\circledR}$ F68 amount in the Lutrol ${ }^{\circledR}$ F68/ Lutrol ${ }^{\circledR}$ F127 ratio upon $T g$ (higher amount of Lutrol ${ }^{\circledR}$ F68 resulted with increased $T g$ ), are correlated with the work of others (Ibrahim et al., 2012; Jeong et al., 2012; Radivojša et al., 2013). It is generally accepted that the PPO, which is hydrophobic, has lowered $T g$ and the PEO, which is hydrophilic, has increased Tg. According to findings of Ibrahim et al. (Ibrahim et al., 2012) addition of Lutrol ${ }^{\circledR}$ F68 to Lutrol ${ }^{\circledR}$ F127 leads to increased $T g$ most likely due to changes of PEO/PPO ratio. Namely, the ratio of PEO/PPO in Lutrol ${ }^{\circledR} F 127$ is $7: 3$, while in Lutrol ${ }^{\circledR} F 68$ it is 8:2 thus when a certain amount of Lutrol ${ }^{\circledR}$ F68 is added to Lutrol ${ }^{\circledR}$ F127 the proportion of PEO increases leading to an increase in $T g$. Similar were the findings of Radivojša and co. and Jeong and co. (Jeong et al., 2012; Radivojša et al., 2013). As they suggest, this observation could be explained by the dehydration of PPO. Having in mind that proportion of PPO in Lutrol ${ }^{\circledR}$ F68 is lower than in Lutrol ${ }^{\circledR}$ F127, gelation would occur at higher concentration and/ or higher 
Table 1. Coded and actual values of independent experimental variables

\begin{tabular}{lccccc}
\hline \multicolumn{1}{c}{ Factor } & \multicolumn{2}{c}{ Low } & \multicolumn{2}{c}{ High } \\
& Coded & $\begin{array}{l}\text { Actual } \\
\text { values }\end{array}$ & $\begin{array}{l}\text { Coded } \\
\text { values }\end{array}$ & $\begin{array}{l}\text { Actual } \\
\text { values }\end{array}$ \\
& -1 & 15 & +1 & 20 \\
\hline A: concentration of Lutrol@ F127(\%) & -1 & 0 & +1 & 0.2 \\
B: Lutrol@ F68/ Lutrol ${ }^{\circledR}$ F127(w/w) & -1 & 0 & +1 & 0.75 \\
C: volume of simulated vaginal fluid (ml) & & & & & \\
\hline
\end{tabular}

Table 2. Experimental design points for studied independent experimental variables in coded values and obtained response for designed formulations, ANOVA output statistics for measured response and optimized batches with predicted $\mathrm{Tg}$ and cross validation of the model

\begin{tabular}{|c|c|c|c|c|c|c|c|c|}
\hline Std & Run & Block & $\begin{array}{c}\text { Factor } 1 \\
\text { A: } \\
\text { F127* }\end{array}$ & $\begin{array}{c}\text { Factor } 2 \\
\text { B: } \\
\text { F68 / F127* }\end{array}$ & $\begin{array}{c}\text { Factor } 3 \\
\text { C: } \\
\text { SVF }\end{array}$ & $\begin{array}{c}\text { Response } \\
\operatorname{Tg}\left({ }^{\circ} \mathrm{C}\right)\end{array}$ & \multicolumn{2}{|c|}{ ANOVA output statistics } \\
\hline 15 & 1 & $\{1\}$ & 0 & 0 & 0 & 32.5 & Suggested model & $2 \mathrm{FI}$ \\
\hline 6 & 2 & $\{1\}$ & 1 & 0 & -1 & 19 & & \\
\hline 17 & 3 & $\{1\}$ & 0 & 0 & 0 & 32.5 & Sum of Square & 2091.91 \\
\hline 16 & 4 & $\{1\}$ & 0 & 0 & 0 & 32,5 & & \\
\hline 1 & 5 & $\{1\}$ & -1 & -1 & 0 & 19.5 & Degrees of freedom & 6 \\
\hline 14 & 6 & $\{1\}$ & 0 & 0 & 0 & 32.5 & & \\
\hline 8 & 7 & $\{1\}$ & 1 & 0 & 1 & 19 & Mean square & 348.65 \\
\hline 4 & 8 & $\{1\}$ & 1 & 1 & 0 & 29 & F-value & 62.72 \\
\hline 9 & 9 & $\{1\}$ & 0 & -1 & -1 & 16 & Prob $>F$ & $<0.0001$ \\
\hline 2 & 10 & $\{1\}$ & 1 & -1 & 0 & 16 & $\mathrm{SD}$ & 2.36 \\
\hline 11 & 11 & $\{1\}$ & 0 & -1 & 1 & 17 & Mean & 30.44 \\
\hline 7 & 12 & $\{1\}$ & -1 & 0 & 1 & 49 & $\mathrm{CV} \%$ & 7.75 \\
\hline 3 & 13 & $\{1\}$ & -1 & 1 & 0 & 1 & PRESS & 361.53 \\
\hline 12 & 14 & $\{1\}$ & 0 & 1 & 1 & 46 & $\mathrm{R}^{2}$ & 0.9766 \\
\hline 10 & 15 & $\{1\}$ & 0 & 1 & -1 & 45.5 & Adj- $R^{2}$ & 0.9611 \\
\hline 13 & 16 & $\{1\}$ & 0 & 0 & 0 & 32.5 & Pred-R² & 0.8312 \\
\hline 5 & 17 & $\{1\}$ & -1 & 0 & -1 & 48.5 & Adequate precision & 22.034 \\
\hline
\end{tabular}

Optimized batches with predicted $T g$ and cross validation of the model

Factors

$\begin{array}{ccc}\text { Run } & \mathrm{F} 127^{*}(\%) & \begin{array}{c}\mathrm{F} 68 / \mathrm{F} 127^{*} \\ (\mathrm{w} / \mathrm{w})\end{array} \\ 1 & 16.39 & 0.06 \\ 2 & 17.36 & 0.09 \\ 3 & 18.24 & 0.12\end{array}$

Response

$\begin{array}{cc}\text { SVF } & \text { Pred. } \\ (\mathrm{ml}) & \operatorname{Tg}\left({ }^{\circ} \mathrm{C}\right)\end{array}$

0.75

0.75

32

32

0.75

Experimental
$\operatorname{Tg}\left({ }^{\circ} \mathrm{C}\right)$

31

31.8

31.9
1- Bias

$(\%)$

3.125

0.625

0.313

* F68 - Lutrol@ F68; F127 - Lutrol@ F127 


\section{temperatures.}

Having in mind that the main objective of the this work was to develop bioresponsive system for vaginal delivery $T g$ of polymer hybrid composites was investigated in the presence of different amounts of SVF thus biomimicring in vivo conditions. Although SVF influence upon $\mathrm{Tg}$ was not considered statistically significant, a positive influence was noticed. SVF dilution of formulations resulted with slight increase in $\mathrm{Tg}$. This could be attributed not only to the decrease in polymers concentration but also to the possible modification of physicochemical properties of the polymer hybrid composites (Aka-Any-Grah et al., 2010). Presumably, the $T g$ increase is related to the increase of the critical micelle concentration or a increase of the critical micelle temperature, or both.

ANOVA statistics for the fitted model for the followed response is presented in Table 2. The predicted $\mathrm{R}^{2}$ (Pred$\mathrm{R}^{2}$ ) and the adjusted $\mathrm{R}^{2}\left(\mathrm{Adj}-\mathrm{R}^{2}\right)$ should be within 0.20 of each other. Otherwise there may be a problem with either the data or the model. Adj-R $\mathrm{R}^{2}$ and Pred- $\mathrm{R}^{2}$ values were in a reasonable agreement, signifying excellent model fit. $\mathrm{R}$ squeared values are higher than 0.95 and adequat precison values are greater than 4 indicating that all suggested models can be used to navigate the design space (Makraduli et al., 2013).

The derived correlations enabled further formulation optimization in term of required temperature for in situ gelling $\left(32^{\circ} \mathrm{C}\right)$. Optimized batches with predicted $\mathrm{Tg}$ of 32 ${ }^{\circ} \mathrm{C}$ were identified (Table 2).

Desirability value is dependent on how the lower and upper limits are set relative to the actual optimum. The goal of optimization is to find a good set of conditions that will meet all the goals, not to get to a desirability value of 1.0. Desirability is simply a mathematical method to find the optimum. The numerical optimization finds a point that maximizes the desirability function. The characteristics of a goal may be altered by adjusting the weight or importance. For several responses and factors, all goals get combined into one desirability function. Desirability graph for $\mathrm{Tg}$ responses is presented on Fig. 2.

Cross-validation of the model was carried out. Confirmation report and the per-cent of relative error of the predicted and experimental values were obtained (Table 2).

\section{Conclusion}

In this study, a novel approach based on thermosensitive bio/mucoadhesive hydrogel system for prolonged release of propolis was developed. Based on the results obtained it can be concluded that chitosan-Lutrol ${ }^{\circledR}$ based systems seem as an attractive candidates for local vaginal delivery of propolis. This attractive approach will be evaluated in further in vitro and in vivo studies carried out on the optimized batches.

\section{References}

Aka-Any-Grah, A., Bouchemal, K., Koffi, A., Agnely, F., Zhang, M., Djabourov, M., Ponchel, G., 2010. Formulation of mucoadhesive vaginal hydrogels insensitive to dilution with vaginal fluids. Eur. J. Pharm. Bipharm. 76(2), 296-303.

Alam, Z., Muyibi, S. A., Toramae, J., 2007. Statistical optimization of adsorption processes for removal of 2,4-dichlorophenol by activated carbon derived from oil palm empty fruit bunches. J. Environ. Sci. 19(6), 674-677.

Annadurai, G., 2000. Design of optimum response surface experiments for adsorption of direct dye on chitosan. Bioprocess Eng. 23(5), 451-455.

Box, G. E. P., Behnken, D. W., 1960. Some new three level designs for the study of quantitative variables. Technometrics 2(4), 455-475.

Bromberg, L. E., Ron, E. S., 1998. Temperature-responsive gels and thermogelling polymer matrices for protein and peptide delivery. Adv. Drug Deliv. Rev. 31(3), 197-221.

Chopra, S., Motwani, S. K., Iqbal, Z., Talegaonkar, S., Ahmad, F. J., Khar, R. K., 2007a. Optimisation of polyherbal gels for vaginal drug delivery by box-behnken statistical design. Eur. J. Pharm. Bipharm. 67(1), 120-131.

Chopra, S., Patil, G. V., Motwani, S. K., 2007b. Release modulating hydrophilic matrix systems of losartan potassium: Optimization of formulation using statistical experimental design. Eur. J. Pharm. Bipharm. 66(1), 73-82.

Escobar-Chávez, J., López-Cervantes, M., Naik, A., Kalia, Y., Quintanar-Guerrero, D., Ganem-Quintanar, A., 2006. Applications of thermo-reversible pluronic f-127 gels in pharmaceutical formulations. J. Pharm. Pharmaceut. Sci. 9(3), 339-358.

Garg, U. K., Kaur, M., Garg, V., Sud, D., 2008. Removal of nickel (ii) from aqueous solution by adsorption on agricultural waste biomass using a response surface methodological approach. Bioresource Technol. 99(5), 1325-1331.

Guenet, J. M., 1992. Thermoreversible gelation of polymers and biopolymers, ed. Academic Press, London.

Ibrahim, E.-S., Ismail, S., Fetih, G., Shaaban, O., Hassanein, K., Abdellah, N., 2012. Development and characterization of thermosensitive pluronic-based metronidazole in situ gelling formulations for vaginal application. Acta Pharm. 62(1), 5970.

Jeong, B., Kim, S. W., Bae, Y. H., 2012. Thermosensitive sol-gel reversible hydrogels. Adv. Drug Deliv. Rev.

Koffi, A. A., Agnely, F., Ponchel, G., Grossiord, J. L., 2006. Modulation of the rheological and mucoadhesive properties of thermosensitive poloxamer-based hydrogels intended for the rectal administration of quinine. Eur. J. Pharm. Sci. 27(4), 328-335.

Makraduli, L., Crcarevska, M. S., Geskovski, N., Dodov, M. G., Goracinova, K., 2013. Factorial design analysis and optimisation of alginate-ca-chitosan microspheres. J. Microencapsul. 30(1), 81-92.

Morlion, E. 2009. Development of a thermosensitive and mucoadhesive vehicle, based on poloxamer and chitosan, for vaginal administration of drugs, Ghent University.

Myers, R., Montgomery, D. C., 1971. Allyn-Bacon, Boston, Massachusetts.

Owen, D. H., Katz, D. F., 1999. A vaginal fluid simulant. Contraception 59(2), 91-95.

Peña, A., Sánchez, N. S., Calahorra, M., 2013. Effects of chitosan 
on candida albicans: Conditions for its antifungal activity. BioMed Res. Int. 2013.

Radivojša, M., Grabnar, I., Grabnar, P. A., 2013. Thermoreversible in situ gelling poloxamer-based systems with chitosan nanocomplexes for prolonged subcutaneous delivery of heparin: Design and $<\mathrm{i}>$ in vitro $</ \mathrm{i}>$ evaluation. Eur. J. Pharm. Sci.

Ricou-Hoeffer, P., Lecuyer, I., Le Cloirec, P., 2001. Experimental design methodology applied to adsorption of metallic ions onto fly ash. Water Res. 35(4), 965-976.

Schmolka, I. R., 1972. Artificial skin i. Preparation and properties of pluronic f - 127 gels for treatment of burns. J. Biomed. Mater. Res. 6(6), 571-582.

Sforcin, J. M., Bankova, V., 2011. Propolis: Is there a potential for the development of new drugs? J. Ethnopharmacol. 133(2), 253-260.

Sionkowska, A., 2011. Current research on the blends of natural and synthetic polymers as new biomaterials: Review. Prog. Polym. Sci. 36(9), 1254-1276.

Tan, I., Ahmad, A., Hameed, B., 2008. Optimization of preparation conditions for activated carbons from coconut husk using response surface methodology. Chem. Eng. J. 137(3), 462-470.

Tikhonov, V. E., Stepnova, E. A., Babak, V. G., Yamskov, I. A., Palma-Guerrero, J., Jansson, H.-B., Lopez-Llorca, L.
V., Salinas, J., Gerasimenko, D. V., Avdienko, I. D., 2006. Bactericidal and antifungal activities of a low molecular weight chitosan and its $n$-/2 (3)-(dodec-2-enyl) succinoyl/derivatives. Carbohyd. Polym. 64(1), 66-72.

Ur-Rehman, T., Tavelin, S., Gröbner, G., 2010. Effect of dmso on micellization, gelation and drug release profile of poloxamer 407. Int. J. Pharm. 394(1), 92-98.

Varshosaz, J., Tabbakhian, M., Salmani, Z., 2008. Designing of a thermosensitive chitosan/poloxamer in situ gel for ocular delivery of ciprofloxacin. Open Drug. Deliv. J. 2, 61-70.

Woolfson, A. D., McCullagh, S. D., Morrow, R. J., Malcolm, R. K., 2007. Vagina and uterus as drug absorbing organs, in: Touitou, E.,Barry, B. W. (Eds), Enhancement in drug delivery. CRC Press, pp.

Yenkar, P., Mayee, R., Nawale, R., Chavan, R., Salunke, T., Bhoyar, V., 2013. Bio responsive in situ gel of clindamycin for vaginal application. RRJPPS 2(2), 26-32.

Yuan, Y., Cui, Y., Zhang, L., Zhu, H.-p., Guo, Y.-S., Zhong, B., Hu, X., Zhang, L., Wang, X.-h., Chen, L., 2012. Thermosensitive and mucoadhesive in situ gel based on poloxamer as new carrier for rectal administration of nimesulide. Int. J. Pharm. 430(1-2), 114-119.

\title{
Биоинспирирани биовештачки полимерни хибридни композити со контролирано ослободување на прополис во вагина I: развој на формулација и оптимизација на температурата на гелирање со примена на експериментален дизајн
}

\author{
Маја Симоноска-Црцаревска, Ана Зафировска-Гапковска, Кристина Младеновска, \\ Рената Славеска Раички, Никола Гешковски, Симона Димчевска, \\ Марија Главаш-Додов
}

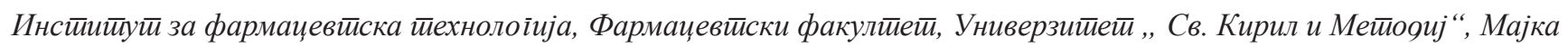
Тереза 47, Скойје, Р. Макеоонија

Клучни зборови: биоинспирирани полимерни хибридни композити, прополис, контролирано ослободување, вагинално локално делување, експериментален дизајн

Целта на овој труд беше формулација и оптимизација на полимерни хибридни композити со прополис со потенцијал за контролирано ослободување, локално во вагината. За формулацијата на интелегентен вагинален систем со особини за in situ гелирање и локално, контролирано ослободување на активната супстанција, беше применет концептот на биовештачко блендирање на цитозан (низок вискозитет, 95\% деацетилација), Lutrol® F127 и Lutrol® F68. 
Определувањето на факторите што влијаат на температурата на гелирање на дизајнираниот систем и оптимизацијата на формулацијата беше направено со примена на методите засновани на моделирање на површината на одговорот, Box-Behnken експерименталниот дизајн. При тоа беше евалуирано влијанието на концентрацијата на Lutrol@ F127, масениот однос на Lutrol® F68 / Lutrol® F127 и волуменот на симулирана вагинална течност врз температурата на гелирање. Сите фактори беа варирани на 3 нивоа и беа направени вкупно 17 формулации што беа карактеризирани од аспект на температурата на гелирање. Влијанието на испитуваните варијабли најдобро може да се опише со помош на 2FI моделот. Еднонасочната ANOVA за овој модел укажа дека статистички значајно влијание имаат концентрацијата на Lutrol® F127, масениот однос на Lutrol® F68 / Lutrol® F127 и нивната интеракција. Добиените резултати укажаа на негативна корелација меѓу температурата на гелирање и концентрацијата на Lutrol® F127, позитивна корелација со масениот однос на Lutrol® F68 / Lutrol® F127 и негативна корелација со нивното взаемно влијание. Утврдените зависности овозможија оптмизиација на формулацијата од аспект на потребната температура за in situ гелирање $\left(32^{\circ} \mathrm{C}\right)$. Моделот беше потврден со вкрстена валидација и беше определен процентот на релативна грешка на предвидените и експериментално добиените вредности. 


\title{
Chemical composition and antimicrobial activity of berry essential oil of Juniperus oxycedrus L. (Cupressaceae) grown wild in Republic of Macedonia
}

\author{
Floresha Sela ${ }^{1}$, Marija Karapandzova ${ }^{1 *}$, Gjose Stefkov ${ }^{1}$, Ivana Cvetkovikj ${ }^{1}$, \\ Elena Trajkovska-Dokikj ${ }^{2}$, Ana Kaftandzieva ${ }^{2}$, Svetlana Kulevanova ${ }^{1}$ \\ ${ }^{1}$ Institute of Pharmacognosy, Faculty of Pharmacy, University"Ss. Cyril and Methodius", Skopje, R. Macedonia \\ ${ }^{2}$ Institute of Microbiology and Parasitology, Faculty of Medicine, University"Ss. Cyril and Methodius", \\ Skopje, R. Macedonia
}

Received: April 2013; Accepted: June 2013

\begin{abstract}
Chemical composition and antimicrobial activity of essential oil isolated from berries from 2 different samples of Juniperus oxycedrus L. (Cupressaceae), growing wild in Republic of Macedonia was investigated. Performing GC/FID/MS analysis, one hundred components were identified, representing $96.0-98.95 \%$ of the oil. The major components were $\alpha$-pinene (22.54- 27.12\%), myrcene (11.26- $15.13 \%$ ) and limonene (2.78-18.06\%). Antimicrobial screening of the $J$. oxycedrus essential oils was made by disc diffusion and broth dilution method against 16 bacterial isolates of Gram positive and Gram negative bacteria and one strain of Candida albicans. The most sensitive bacteria was Haemophilus influenzae $(\mathrm{MIC}=125 \mu \mathrm{l} / \mathrm{ml})$. The essential oils showed moderate antimicrobial activity against Streptococcus pneumoniae, Staphylococcus aureus, Streptococcus agalactiae, Streptococcus pyogenes, Corynebacterium spp., Escherichia coli and Campilobacter jejuni (MIC $>500 \mu \mathrm{l} / \mathrm{ml}$ ) and no activity against Candida albicans, Staphylococcus epidermidis, Acinetobacter spp., Salmonella enteritidis, Shigella flexnery, Klebsiella pneumonia, Pseudomonas aeruginosa, Enterococcus and Proteus mirabilis.
\end{abstract}

Keywords: Juniperus oxycedrus, berry essential oil, oil composition, GC/FID/MS, antimicrobial activity.

\section{Introduction}

Juniperus oxycedrus L. (Cupressaceae) is a hardy spreading plant, that vary in size from a low shrub to a tree of about $6 \mathrm{~m}$. The leaves are tiny, narrow and prickly and are reason for people' name of the plant:"Prickly Juniper". The cones are yellow and rounded, and the fruits are berry-like, growing in clusters, and black when ripe. The plant is known as Cade juniper as well, mainly because of the oil that is obtained through destructive distillation of the wood. Cade oil is dark, aromatic oil with a strong smoky

\footnotetext{
* Marija Karapandzova@ff.ukim.edu.mk; marijakarapandzova@yahoo.com
}

smell which is used in some cosmetics and traditional skin treatment drugs, as well as an incense (Lamnauer, 2005).

$J$. oxycedrus is known as Mediterranean equivalent of the common juniper, native across the Mediterranean region from Morocco and Portugal, southern France and east to Iran, Lebanon and Israel. It grows on rocky sites from sea level up to $1600 \mathrm{~m}$ altitude. Among J. oxycedrus interesting subspecies are $J$. oxycedrus var. badia H.Gay (syn. J. oxycedrus subsp. badia (H.Gay) Debeaux), distinguished on the basis of larger cones and described from northern Algeria, but also reported for Portugal and Spain (Salido et al., 2002; Velasco-Negueruela et al., 2003) and $J$. oxycedrus subsp. macrocarpa (S. et Sm.) Ball., confined to Mediterranean coastal sands, which differs in the broader 
leaves 2-3 mm wide and larger cones (Stassi et al., 1995).

Aromatical oils from different parts of $J$. oxycedrus have been used since antiquity for fragrance, flavoring, medicinal, antibacterial, insecticidal, and cosmetic purposes. In folk medicine, they have been recommended as a mouth analgesic and for stomach disorders. Berries of this plant are used as a spice, particularly in European cuisine, and essential oil is used for production of beverages such as gin, to which the oil gave distinguishing flavor. The composition of leaf essential oil of J. oxycedrus from Morocco (Derwich and Chabir, 2011), Tunisia (Medini et al., 2010), Greece (Adams et al., 1999), Corsica (Boti et al., 2006), and Allgeria (Dob et al., 2006) has been reported in varying details. The oil is characterized by large amount of $\alpha$-pinene followed by smaller amounts of sabinene, limonene, $\beta$-pinene, caryophyllene oxide and myrcene (Derwich et al., 2010; Derwich and Chabir, 2011; Adams et al., 1999). Berry essential oil of J. oxycedrus was examined in Italy and similar composition to that of the leaf essential oil was found with predominant amounts of $\alpha$-pinene followed by smaller amounts of $\beta$-pinene, $\delta$-3-carene, sabinene, myrcene, $\alpha$-phellandrene, limonene and germacrene D (Angioni et al., 2003). Additionally, authors found that ripeness of the berries does not have large influence on the oil composition. Boti et al. (2006) found $\alpha$-pinene, $\beta$-phellandrene and $\delta$-3-carene as the most abundant constituents in the berry essential oil from Corsica. The berry essential oil of $J$. oxycedrus ssp. badia from Spain contained $\alpha$-pinene and myrcene as the predominant components (Velasco-Negueruela et al., 2003), while the oil of J. oxycedrus ssp. macrocarpa contained $\alpha$-pinene, germacrene D, myrcene, abietadiene and cis-calamenene as major constituents (Medini et al., 2012).

J. oxycedrus essential oil possess broad spectrum of biological activities: antioxidant (Loizzo et al. 2007), antimicrobial (Angioni et al., 2003; Medini et al., 2012), antifungal (Cavaleiro et al., 2006), wound healing (Tumen et al., 2012), insecticidal (Athanassiou et al., 2013), herbicidal (Ismail et al., 2011), etc. The oil with predominated content of $\alpha$-pinene and $\beta$-myrcene possesses antiviral activity against HIV-1 (Loizzo, 2008). Antibacterial and antifungal activity against different pathological strains that grow on food makes possible use of $J$. oxycedrus essential oil as food preservative (Stassi at al. 1996).

In Macedonian flora, only J. oxycedrus L. subsp. oxycedrus is present (Micevski, 1989). This species is spread throughout the whole territory of Republic of Macedonia, except on very high altitudes on mountains in the continental part. Up to now, J. oxycedrus was not chemically investigated and no testing of possible biological and pharmacological activities was performed. Therefore the aim of the present study was analysis of chemical composition of berry essential oil of this plant and evaluation of its antimicrobial activity.

\section{Material and methods}

\section{Plant materials}

The terminal twigs with berries were collected from two different localities in R. Macedonia: Velestovo village near Ohrid Lake and Vodno Mtn., near Skopje, in late autumn 2010 and 2012. Plant identity was verified as Juniperus oxycedrus L., and herbarium voucher specimen $\mathrm{N}^{\circ}$ JO-1/10, No JO-1/12, were deposited at the Department of Pharmaceutical Botany, Institute of Pharmacognosy, Faculty of Pharmacy, Skopje, R. Macedonia.

The plant material was dried at room temperature. Just before essential oil isolation, the berries were separated from leaves and branches and minced properly.

\section{Chemicals}

Dimethylsulfoxide was purchased from Sigma-Aldrich (Steinheim, Germany), sodium chloride and anhydrous sodium sulfate from Merck (Darmstadt, Germany) and from Kemica (Zagreb, Croatia), respectively, while xylene was purchased from Alkaloid (Skopje, R. Macedonia).

\section{Essential oil isolation}

Essential oil isolation from plant material was made by steam distillation in special all-glass Clevenger type apparatus. For that purpose, $20 \mathrm{~g}$ of minced plant material was distilled for 4 hours. After isolation, anhydrous sodium sulfate was added to remove residual water from the oil. The essential oil yield was calculated on dried plant material and was expressed in $\mathrm{ml} / \mathrm{kg}$. For GC/FID/MS analysis, the essential oil was dissolved in xylene to obtain $1 \mu \mathrm{l} / \mathrm{ml}$ oil solution.

\section{Gas chromatography (GC) and gas chromatography/mass spectrometry (GC/MS)}

Essential oil samples were analyzed on Agilent 7890A Gas Chromatography system equipped with FID detector and Agilent 5975C Mass Quadrupole detector as well as capillary flow technology which enables simultaneous analysis of the samples on both detectors. For that purpose, HP-5ms capillary column $(30 \mathrm{~m} \times 0.25 \mathrm{~mm}$, film thickness $0.25 \mu \mathrm{m}$ ) was used. Operating conditions were as follows: oven temperature at $60{ }^{\circ} \mathrm{C}(5 \mathrm{~min}), 1{ }^{\circ} \mathrm{C} / \mathrm{min}$ to 80 ${ }^{\circ} \mathrm{C}(2 \mathrm{~min})$ and $5{ }^{\circ} \mathrm{C} / \mathrm{min}$ to $280{ }^{\circ} \mathrm{C}(5 \mathrm{~min})$; helium as carrier gas at a flow rate of $1 \mathrm{ml} / \mathrm{min}$; injector temperature 260 ${ }^{\circ} \mathrm{C}$ and that of the FID $270{ }^{\circ} \mathrm{C} .1 \mu \mathrm{l}$ of each sample was injected at split ratio 1:1. The mass spectrometry conditions were: ionization voltage $70 \mathrm{eV}$, ion source temperature 230 ${ }^{\circ} \mathrm{C}$, transfer line temperature $280{ }^{\circ} \mathrm{C}$ and mass range from 50 - $500 \mathrm{Da}$. The MS was operated in scan mode. 


\section{Identification of the components}

Identification of the components present in essential oils was made by comparing mass spectra of components in essential oils with those from Nist, Wiley and Adams mass spectra libraries, by AMDIS (Automated Mass Spectral Deconvolution and Identification System) and by comparing literature and estimated Kovat's (retention) indices that were determined using mixture of homologous series of normal alkanes from $\mathrm{C}_{9}$ to $\mathrm{C}_{25}$ in hexane, under the same above mentioned conditions.

The percentage ratio of essential oils components was computed by the normalization method of the GC/FID peak areas without any correction factors.

\section{Antimicrobial activity: microbial strains and cultures}

16 bacterial isolates representing both Gram positive and Gram negative bacteria and one strain of Candida albicans were used for antimicrobial screening. Five isolates were standard strains (Staphylococcus aureus ATCC 29213, Escherichia coli 25927, Klebsiella pneumoniae ATCC 700603, Pseudomonas aeruginosa ATCC 27853 and Candida albicans ATCC 10231). The remaining 12 bacterial strains (Staphylococcus epidermidis, Enterococcus, Streptococcus pyogenes, Streptococcus agalactiae, Streptococcus pneumoniae, Haemophylus influenzae, Proteus mirabilis, Salmonella enteritidis, Salmonella enteritidis, Shigella flexneri, Campylobacter jejuni, and Acinetobacter spp.) were clinical isolates provided from the Institute of Microbiology and Parasitology, Faculty of Medicine, Skopje, R. Macedonia.

A nutrient (Mueller Hinton) agar from Merck (Darmstadt, Germany), blood agar (Oxoid, Basingstoke, UK) and Sabouraund agar (bioMerieux, Durham, NC) were used for growing of the microbial strains.

\section{Disc diffusion method}

Disc diffusion method was used for screening the antimicrobial activity of all essential oils in order to determine the growth inhibition zones of studied microorganisms that occur around certain essential oil. In this regard, microorganisms were suspended in sterile broth with turbidity corresponding to 0.5 and $1 \mathrm{Mc}$ Farland (approximate by $10^{7}$ $10^{8} \mathrm{CFU} / \mathrm{ml}$ ) for all bacteria and for Candida albicans, respectively. The microbial suspensions were streaked over the surface of the agar media using a sterile cotton swabs to ensure uniform inoculation. After inoculation of microorganisms, discs of $6 \mathrm{~mm}$ in diameter were made at wellspaced intervals. They were filled with $85 \mu \mathrm{l}$ of $50 \%$ solutions of essential oils in dimethylsulfoxide (DMSO, Sigma-Aldrich, Germany) and one disc was filled only with DMSO as a control. The plates were incubated at $37^{\circ} \mathrm{C}$, aerobically for 24 hours. The growth inhibition zones were measured after incubation of the isolates under their optimal growth conditions and were ranged between $6 \mathrm{~mm}$ and
$30 \mathrm{~mm}$ in diameter. The antimicrobial activity was determined according to the diameters of the inhibition zones (0-14 mm resistant - R, 14-19 mm moderate susceptible $\mathrm{M}$ and 19-30 susceptible microorganisms - S).

\section{Broth dilution method}

This method was used in order to determine minimal inhibitory concentration (MIC) of the particular essential oil (50\% solution in DMSO) that had revealed antimicrobial activity by disc diffusion method. For that purposes, $25 \mu \mathrm{l}$ of those essential oils were diluted in equal quantities of $0.9 \%$ sodium chloride solution, to make them with the concentration of $25 \%$. This concentration was decreased five times, subsequently, by adding $25 \mu 1$ of each bacterial or fungal suspension, thus the final concentrations were: $12.5 \%, 6.2 \%, 3.1 \%, 1.5 \%$ and $0.7 \%$ or $125 \mu \mathrm{l} / \mathrm{ml}, 62 \mu \mathrm{l} / \mathrm{ml}$, $31 \mu \mathrm{l} / \mathrm{ml}, 15 \mu \mathrm{l} / \mathrm{ml}$ and $7 \mu \mathrm{l} / \mathrm{ml}$, respectively. $15 \mu \mathrm{l}$ of each bacterial or fungal suspensions with these particular concentrations were inoculated on solid media (Mueller-Hinton agar, blood agar, Sabouraund agar), depending on the type of microorganism. The growth of any microorganism was evaluated after its incubation under the optimal growth conditions. The lowest concentration of essential oil which was able to inhibit the growth of the particular microorganism was considered as its minimal inhibitory concentration (MIC).

\section{Results and discussion}

The obtained essential oils of $J$. oxycedrus were transparent, agile, light yellowish liquids with specific and very strong turpentine odor. Using GC/FID/MS a total of 100 components were identified, representing $96.01-98.95 \%$ of the oils. Among different classes of components, the most abundant fraction for Velestovo and Vodno oils were the monoterpene hydrocarbons (MH) $(59.23 \%$ and $60.43 \%$, respectively), followed by the sesquiterpene hydrocarbons (SH) $(21.58 \%$ and $28.72 \%$, respectively) (Table 1$)$. Both samples of essential oils, contained smaller amounts of oxygen-containing monoterpenes (OM) $(5.63 \%$ and $3.67 \%$, respectively) as well as oxygen-containing sesquiterpenes (OS) (9.13\% and 5.75\%, respectively) (Table 1).

Chemical analysis of the berry essential oil of $J$. oxycedrus showed presence of tree main components: $\alpha$-pinene (22.54\% and $27.12 \%), \beta$-myrcene (11.26\% and $15.13 \%)$ and limonene $(18.06 \%$ and $2.78 \%)$. Additionally, $\beta$-pinene $(2.60 \%$ and $3.14 \%)$, trans-caryophyllene $(6.18 \%$ and $2.67 \%), \alpha$-humulene $(4.65 \%$ and $2.68 \%$ ), and $\delta$-cadinene (4.16\% and $2.23 \%$ for Velestovo and Vodno, respectively) were determined in smaller amounts. Larger amounts of germacrene D (11.50\%) were found only in the sample from Vodno. 
Table 1. Chemical composition (\%) of Juniperus oxycedrus berry essential oils

\begin{tabular}{|c|c|c|c|c|c|}
\hline No. & Components & KIL & KIE & Velestovo 2010 & Vodno 2012 \\
\hline 1 & Tricyclene & 921 & 938.9 & 0.02 & 0.03 \\
\hline 2 & $\alpha$-Thujene & 931 & 940.8 & 0.26 & 0.75 \\
\hline 3 & $\alpha$-Pinene & 932 & 949.4 & 22.54 & 27.12 \\
\hline 4 & Camphene & 946 & 955.6 & 0.45 & 0.26 \\
\hline 5 & Verbenene & 961 & 966.9 & - & 0.04 \\
\hline 6 & Sabinene & 969 & 975.1 & 1.15 & 9.17 \\
\hline 7 & $\beta$-Pinene & 974 & 976.2 & 2.60 & 3.14 \\
\hline 8 & $\beta$-Myrcene & 988 & 990.6 & 11.26 & 15.13 \\
\hline 9 & $\alpha$-Phellandrene & 1002 & 997.1 & - & 0.05 \\
\hline 10 & $\delta^{3}$-Carene & 1008 & 1001.5 & - & 0.13 \\
\hline 11 & $\alpha$-Terpinene & 1014 & 1007.2 & 0.61 & 0.27 \\
\hline 12 & p-Cymene & 1020 & 1014.3 & 0.13 & 0.09 \\
\hline 13 & Limonene & 1024 & 1018.6 & 18.06 & 2.78 \\
\hline 14 & $\beta$-Phellandrene & 1025 & 1019.9 & - & - \\
\hline 15 & $Z$ - $\beta$-Ocimene & 1032 & 1037.1 & - & 0.02 \\
\hline 16 & $E$ - $\beta$-Ocimene & 1044 & 1037.3 & - & 0.04 \\
\hline 17 & $\gamma$-Terpinene & 1054 & 1046.4 & 1.14 & 0.54 \\
\hline 18 & cis-Sabinene hydrate & 1065 & 1054.2 & - & 0.13 \\
\hline 19 & Terpinolene & 1086 & 1076.3 & 1.03 & 0.94 \\
\hline 20 & Linalool & 1095 & 1091.2 & 0.69 & 0.77 \\
\hline 21 & 2-Methyl butyl isovalerate & 1103 & 1095.6 & 0.22 & - \\
\hline 22 & cis-p-Menth-2-en-1-ol & 1118 & 1114.2 & - & 0.05 \\
\hline 23 & $\alpha$-Campholenal & 1122 & 1121.0 & - & 0.03 \\
\hline 24 & trans-Pinocarveol & 1135 & 1135.4 & - & 0.03 \\
\hline 25 & trans-p-Menth-2-en-1-ol & 1136 & 1138.2 & - & 0.05 \\
\hline 26 & trans-Verbenol & 1140 & 1143.9 & - & 0.06 \\
\hline 27 & Citronelall & 1148 & 1155.0 & - & 0.02 \\
\hline 28 & $\beta$-Pinene oxide & 1154 & 1159.4 & - & 0.03 \\
\hline 29 & Borneol & 1165 & 1163.2 & 0.14 & 0.04 \\
\hline 30 & $p$ - Menth-1,5-dien-8-ol & 1166 & 1166.2 & - & 0.02 \\
\hline 31 & Terpinen-4-ol & 1174 & 1162.3 & 1.60 & 1.13 \\
\hline 32 & $p$-Cymene-8-ol & 1179 & 1184.4 & - & 0.04 \\
\hline 33 & $\alpha$-Terpineol & 1186 & 1184.6 & 0.60 & 0.18 \\
\hline 34 & Myrtenol & 1194 & 1188.5 & - & 0.05 \\
\hline 35 & Methyl chavicol & 1195 & 1190.4 & - & 0.03 \\
\hline 36 & Verbenone & 1204 & 1197.4 & - & 0.04 \\
\hline 37 & endo-Fenchyl acetate & 1218 & 1207.5 & - & 0.02 \\
\hline 38 & $\beta$-Citronellol & 1223 & 1220.1 & 0.30 & 0.15 \\
\hline 39 & trans -Chrysanthenyl acetate & 1235 & 1224.6 & - & 0.05 \\
\hline 40 & Thymol methyl ether & 1232 & 1225.3 & - & - \\
\hline 41 & Neral & 1235 & 1232.2 & - & 0.08 \\
\hline 42 & Hexyl isovalerate & 1241 & 1232.6 & 0.05 & - \\
\hline 43 & Isoamyl hexanoate & 1246 & 1240.9 & 0.08 & - \\
\hline 44 & Geraniol & 1249 & 1247.3 & - & 0.06 \\
\hline 45 & cis-Myrtanol & 1250 & 1249.2 & - & $\operatorname{tr}$ \\
\hline 46 & Methyl citronellate & 1257 & 1252.7 & - & 0.05 \\
\hline 47 & Geranial & 1264 & 1261.8 & - & 0.07 \\
\hline 48 & Bornyl acetate & 1284 & 1261.6 & 0.09 & 0.25 \\
\hline 49 & trans-Sabinyl acetate & 1289 & 1279.6 & 1.29 & - \\
\hline 50 & 2-Undecanone & 1293 & 1282.3 & - & 0.07 \\
\hline 51 & Terpinen-4-ol-acetate & 1299 & 1286.9 & - & 0.02 \\
\hline 52 & Myrtenil acetate & 1324 & 1310.6 & - & 0.12 \\
\hline 53 & $\delta$-Elemene & 1335 & 1322.4 & 0.04 & 0.22 \\
\hline 54 & $\alpha$-Cubebene & 1345 & 1335.3 & 0.09 & 0.59 \\
\hline 55 & Citronellyl acetate & 1350 & 1339.2 & - & 0.08 \\
\hline 56 & Dihydro carveol acetate & 1356 & 1350.0 & - & 0.03 \\
\hline
\end{tabular}




\begin{tabular}{|c|c|c|c|c|c|}
\hline No. & Components & KIL & KIE & Velestovo 2010 & Vodno 2012 \\
\hline 57 & $\alpha$-Ylangene & 1373 & 1356.7 & - & 0.02 \\
\hline 58 & $\alpha$-Copaene & 1374 & 1361.5 & 0.20 & 0.58 \\
\hline 59 & Geranyl acetate & 1379 & 1368.9 & - & 0.23 \\
\hline 60 & $\beta$-Bourbonene & 1387 & 1369.9 & 0.03 & - \\
\hline 61 & $\beta$-Elemene & 1389 & 1378.2 & 0.23 & 2.09 \\
\hline 62 & Longipinene & 1400 & 1384.6 & - & - \\
\hline 63 & Sibirene & 1400 & 1386.8 & - & 0.31 \\
\hline 64 & $\beta$-Longifolene & 1407 & 1390.2 & - & $\operatorname{tr}$ \\
\hline 65 & $\alpha$-cis-Bergamotene & 1411 & 1397.9 & - & 0.01 \\
\hline 66 & trans-(E)-Caryophyllene & 1417 & 1404.0 & 6.18 & 2.67 \\
\hline 67 & $\beta$-Copaene & 1430 & 1413.0 & 0.11 & 0.35 \\
\hline 68 & $\gamma$-Elemene & 1434 & 1418.3 & 0.45 & 2.08 \\
\hline 69 & $\alpha$-Guaiene & 1437 & 1419.2 & 0.07 & - \\
\hline 70 & 6,9-Guaidiene & 1442 & 1424.6 & 0.08 & \\
\hline 71 & Unknown & I & 1435.6 & - & 0.19 \\
\hline 72 & $\alpha$-Humulene & 1454 & 1439.3 & 4.65 & 2.68 \\
\hline 73 & cis-Muurola-4,(14),5-diene & 1465 & 1448.0 & $\operatorname{tr}$ & 0.14 \\
\hline 74 & Germacrene D & 1484 & 1471.5 & 1.89 & 11.50 \\
\hline 75 & $\beta$-Selinene & 1485 & 1473.8 & 0.11 & $\operatorname{tr}$ \\
\hline 76 & Bicyclogermacrene & 1494 & 1501.7 & 0.20 & - \\
\hline 77 & $\alpha$-Muurolene & 1500 & 1483.7 & 1.07 & 1.71 \\
\hline 78 & $\gamma$-Cadinene & 1513 & 1496.9 & 1.16 & 0.69 \\
\hline 79 & $\delta$-Cadinene & 1522 & 1506.8 & 4.16 & 2.23 \\
\hline 80 & trans-Cadina-1,4-diene & 1533 & 1514.7 & 0.15 & 0.12 \\
\hline 81 & $\alpha$-Cadinene & 1537 & 1519.9 & - & 1.71 \\
\hline 82 & Elemol & 1549 & 1532.1 & 0.10 & 0.19 \\
\hline 83 & Unknown & / & 1537.4 & 0.42 & 0.09 \\
\hline 84 & Germacrene B & 1559 & 1543.3 & 0.41 & 1.73 \\
\hline 85 & Germacrene D-4-ol & 1574 & 1560.7 & - & 1.37 \\
\hline 86 & Spathulenol & 1577 & 1563.0 & 0.06 & $\operatorname{tr}$ \\
\hline 87 & Caryophyllene oxide & 1581 & 1593.2 & 1.63 & 0.17 \\
\hline 88 & Humulene epoxide II & 1608 & 1593.6 & 1.80 & 0.17 \\
\hline 89 & 1,10-di-epi-Cubenol & 1618 & 1596.5 & $\operatorname{tr}$ & $\operatorname{tr}$ \\
\hline 90 & Junenol & 1618 & 1602.4 & 0.17 & $\operatorname{tr}$ \\
\hline 91 & 1-epi-Cubenol & 1627 & 1610.7 & 0.26 & 0.25 \\
\hline 92 & $\gamma$-Eudesmol & 1630 & 1613.9 & 0.17 & - \\
\hline 93 & $\tau$-Murolol & 1640 & 1624.7 & 1.55 & 0.88 \\
\hline 94 & $\alpha$-Muurolol & 1645 & 1613.4 & 0.38 & $\operatorname{tr}$ \\
\hline 95 & $\alpha$-Cadinol & 1653 & 1638.8 & 2.60 & 1.16 \\
\hline 96 & Cadalene & 1675 & 1657.1 & $\operatorname{tr}$ & - \\
\hline 97 & Abieta-8,12-diene & 2022 & 2004.0 & $\operatorname{tr}$ & $\operatorname{tr}$ \\
\hline 98 & Abietatriene & 2054 & 2024.8 & $\operatorname{tr}$ & $\operatorname{tr}$ \\
\hline 99 & Abietadiene & 2080 & 2172.8 & $\operatorname{tr}$ & $\operatorname{tr}$ \\
\hline \multirow[t]{6}{*}{100} & Sandarocopimarinal & 2184 & 2172.5 & $\operatorname{tr}$ & $\operatorname{tr}$ \\
\hline & Total & & & 96.01 & 98.95 \\
\hline & Monoterpene hydrocarbons (MH) & & & 59.23 & 60.43 \\
\hline & Oxygen containing monoterpenes (OM) & & & 5.63 & 3.67 \\
\hline & Sesquiterpene hydrocarbons (SH) & & & 21.58 & 28.72 \\
\hline & Oxygen containing sesquiterpenes (OS) & & & 9.13 & 5.75 \\
\hline
\end{tabular}

KIL - Kovat's (retention) index - literature data (Adams, 2007); KIE - Kovat's (retention) index experimentally determined (AMDIS); $(-)$ - not found, $\operatorname{tr}-\operatorname{traces}<0.02$. 
Table 2. Antimicrobial activity of the berry essential oil of Juniperus oxycedrus.

\begin{tabular}{lccc}
\hline \hline Microorganism & & Velestovo & Vodno \\
\hline Streptococcus & $\mathrm{DD}$ & $\mathrm{M}$ & $\mathrm{R}$ \\
pneumoniae & $\mathrm{MIC}$ & $>500$ & $\mathrm{n} . \mathrm{m}$. \\
Staphylococcus & $\mathrm{DD}$ & $\mathrm{M}$ & $\mathrm{R}$ \\
aureus & $\mathrm{MIC}$ & $>500$ & $\mathrm{n} . \mathrm{m}$. \\
Staphylococcus & $\mathrm{DD}$ & $\mathrm{R}$ & $\mathrm{R}$ \\
epidermidis & $\mathrm{MIC}$ & $\mathrm{n} . \mathrm{m}$. & $\mathrm{n} . \mathrm{m}$. \\
Streptococcus & $\mathrm{DD}$ & $\mathrm{M}$ & $\mathrm{R}$ \\
agalactiae & $\mathrm{MIC}$ & $>500$ & $\mathrm{n} . \mathrm{m}$. \\
Streptococcus & $\mathrm{DD}$ & $\mathrm{M}$ & $\mathrm{M}$ \\
pyogenes & $\mathrm{MIC}$ & $>500$ & $>500$ \\
Enterococcus & $\mathrm{DD}$ & $\mathrm{R}$ & $\mathrm{R}$ \\
& $\mathrm{MIC}$ & $\mathrm{n} . \mathrm{m}$. & $\mathrm{n} . \mathrm{m}$. \\
Corynebacterium spp. & $\mathrm{DD}$ & $\mathrm{M}$ & $\mathrm{R}$ \\
& $\mathrm{MIC}$ & $>500$ & $\mathrm{n} . \mathrm{m}$. \\
Haemophilus & $\mathrm{DD}$ & $\mathrm{S}$ & $\mathrm{S}$ \\
influenzae & $\mathrm{MIC}$ & 125 & 125 \\
Acinetobacter spp. & $\mathrm{DD}$ & $\mathrm{R}$ & $\mathrm{R}$ \\
& $\mathrm{MIC}$ & $\mathrm{n} . \mathrm{m}$. & $\mathrm{n} . \mathrm{m}$. \\
Escherichia coli & $\mathrm{DD}$ & $\mathrm{R}$ & $\mathrm{M}$ \\
& $\mathrm{MIC}$ & $\mathrm{n} . \mathrm{m}$. & $>500$ \\
Salmonella enteritidis & $\mathrm{DD}$ & $\mathrm{R}$ & $\mathrm{R}$ \\
& $\mathrm{MIC}$ & $\mathrm{n} . \mathrm{m}$. & $\mathrm{n} . \mathrm{m}$. \\
Shigella flexneri & $\mathrm{DD}$ & $\mathrm{R}$ & $\mathrm{R}$ \\
& $\mathrm{MIC}$ & $\mathrm{n} . \mathrm{m}$. & $\mathrm{n} . \mathrm{m}$. \\
Campylobacter jejuni & $\mathrm{DD}$ & $\mathrm{M}$ & $\mathrm{M}$ \\
& $\mathrm{MIC}$ & $>500$ & $>500$ \\
Klebsiella & $\mathrm{DD}$ & $\mathrm{R}$ & $\mathrm{R}$ \\
pneumoniae & $\mathrm{MIC}$ & $\mathrm{n} . \mathrm{m}$. & $\mathrm{n} . \mathrm{m}$. \\
Pseudomonas & $\mathrm{DD}$ & $\mathrm{R}$ & $\mathrm{R}$ \\
aeruginosa & $\mathrm{MIC}$ & $\mathrm{n} . \mathrm{m}$. & $\mathrm{n} . \mathrm{m}$. \\
Proteus mirabilis & $\mathrm{DD}$ & $\mathrm{R}$ & $\mathrm{R}$ \\
& $\mathrm{MIC}$ & $\mathrm{n} . \mathrm{m}$. & $\mathrm{n} . \mathrm{m}$. \\
Candida albicans & $\mathrm{DD}$ & $\mathrm{R}$ & $\mathrm{R}$ \\
& $\mathrm{MIC}$ & $\mathrm{n} . \mathrm{m}$. & $\mathrm{n} . \mathrm{m}$. \\
\hline & & & \\
& & & \\
& & &
\end{tabular}

DD - Disc diffusion (zone of inhibition including the diameter of disc $6 \mathrm{~mm}$ ), $\mathrm{R}=$ resistant with zone of inhibition 0-14 $\mathrm{mm}, \mathrm{M}$ $=$ moderate susceptible with zone of inhibition $14-19 \mathrm{~mm}$ and $\mathrm{S}$ = susceptible microorganism with zone of inhibition 19-30 mm); MIC - minimum inhibitory concentration $(\mu \mathrm{l} / \mathrm{ml})$; n.m. - not measured.

Similar composition of the berry essential oil was found for the Spanish $J$. oxycedrus ssp. badia with $\alpha$-pinene $(59.8-61.5 \%)$ and myrcene (18.5-18.6\%) as major constituents of the oil (Velasco-Negueruela et al., 2003). Furthermore, in unripe berries, Salido et al. (2002) found essential oil rich with $\alpha$-pinene $(65 \%)$ and smaller amounts of myrcene, limonene, germacrene D and $\gamma$-muurolene. Medini et al. (2011) reported that the amounts of $\alpha$-pi- nene, germacrene D, myrcene, abietadiene and cis-calamenene vary according to the phonological stage of $J$. oxycedrus ssp. macrocarpa. Berry essential oil of $J$. oxycedrus ssp. macrocarpa from Greece contained $63.03 \%$ of $\alpha$-pinene (Stassi et al., 1995). Comparing to the leaf essential oil composition of $J$. oxycedrus, similarities could be found as the leaf essential oil contain $\alpha$-pinene as the most abundant constituent (Derwich et al., 2010; Derwich et al., 2011; Boti et al., 2006; Salido et al., 2002; Adams et al., 1999; Stassi et al., 1995; Medini et al., 2010; Angioni et al., 2003).

Antimicrobial screening of the essential oils was made by disc diffusion and broth dilution method against 16 bacterial isolates of Gram positive and Gram negative bacteria and one strain of Candida albicans. The most sensitive bacteria to antimicrobial effects of Juniperus oxycedrus berry essential oils was Haemophilus influnzae (MIC $=125 \mu \mathrm{l} / \mathrm{ml})($ Table 2$)$.

The berry essential oil showed moderate antimicrobial activity against Streptococcus pneumoniae, Staphylococcus aureus, Streptococcus agalactiae, Streptococcus pyogenes, Corynebacterium spp., Escherichia coli and Campilobacter jejuni with MIC $>500 \mu \mathrm{l} / \mathrm{ml}$. No activity against Candida albicans, Staphylococcus epidermidis, Acinebacter spp., Salmonella enteritidis, Shigella flexnery, Klebsiella pneumonia, Pseudomonas aeruginosa, Enterococcus and Proteus mirabilis was found.

According to literature data, essential oils of $J$. oxycerdrus, J. phoenicea and J. communis were tested against Candida albicans, Staphylococcus aureus, Escherichia coli and Pseudomonas aeruginosa. The results obtained led to a non-significant inhibitory effect, although essential oil of $J$. phoenicea and leaf oil of $J$. oxycerdrus exhibited rather good or weak activity against Candida albicans and Staphylococcus aureus (Angioni et al., 2003). The study of the antimicrobial activity of leaf essential oil of J. oxycedrus from Tunisia showed that Escherichia coli was found to be extremely resistant to this oil while Staphylococcus aureus was the most sensitive strain with MIC ranged from 600 to $650 \mu \mathrm{g} / \mathrm{ml}$ (Medini et al., 2012). J. oxycerdrus leaf essential oil provided to be an emergent alternative as antifungal agent against dermatophyte strains. $\delta$-3-carene was shown to be a fundamental compound for this activity (Cavaliero et al., 2006).

\section{Conclusion}

The major components in the essential oil of two samples of berries of Juniperus oxycedrus L. (Cupressaceae), growing wild in R. Macedonia were $\alpha$-pinene, myrcene and limonene. $\beta$-pinene, caryophyllene, $\alpha$-humulene and $\delta$-cadinene were determinate in smaller amounts while larger amount of germacrene $\mathrm{D}$ was found only in one sample of the oil. Antimicrobial screening of the essential oils showed that the most sensitive bacteria was Haemophilus influenzae $(\mathrm{MIC}=125 \mu \mathrm{l} / \mathrm{ml})$. The $J$. oxycedrus essential 
oil showed moderate antimicrobial activity against Streptococcus pneumoniae, Staphylococcus aureus, Streptococcus agalactiae, Streptococcus pyogenes, Corynebacterium spp., Escherichia coli and Campilobacter jejuni (MIC > $500 \mu \mathrm{l} / \mathrm{ml}$ ) and no activity against other investigated bacteria and Candida albicans.

\section{References}

Adams, R., Altarejos, J., Fermandez, C., Camacho, A., 1999. The leaf essential oils and taxonomy of Juniperus oxycedrus L. subsp. oxycedrus, subsp. badia (H. Gay) Debeaux, and subsp. macrocarpa (Sibth. \& Sm.) Ball. J. Ess. Oil. Res. 11, 167-172.

Adams, R., 2007. Identification of Essential Oil Components by Gas Chromatography/Mass Spectrometry, $4^{\text {th }}$ Ed. Allured Publishing Corporation, IL, USA, pp. 9-31.

Angioni, A., Barra, A., Russo, M.T., Coroneo, V., Dessi, S., Cabras, P., 2003. Chemical composition of the essential oils of Juniperus from ripe and unripe berries and leaves and their antimicrobial activity. Journal of Agricultural and Food Chemistry. 51 (10), 3073-3078.

Athanassiou, C.G., Kavallieratos, N.G., Evergetis, E., Katsoula, A.M., Haroutounian, S.A., 2013. Insecticidal Efficacy of Silica Gel With Juniperus oxycedrus ssp. oxycedrus (Pinales: Cupressaceae) Essential Oil Against Sitophilus oryzae (Coleoptera: Curculionidae) and Tribolium confusum (Coleoptera: Tenebrionidae). Journal of Economic Entomology. 106 (4), 1902-1910.

Boti, J.B., Bighelli, A., Cavaleiro, C., Salgueiro, L., Casanova, J., 2006. Chemical variability of Juniperus oxycedrus ssp. oxycedrus berry and leaf oils from Corsica, analysed by combination of GC, GC-MS and ${ }^{13} \mathrm{C}-\mathrm{NMR}$. Flavour and Fragrance Journal. 21 (2), 268-273.

Cavaleiro, C., Pinto, E., Gonçalves, M.J., Salgueiro, L., 2006. Antifungal activity of Juniperus essential oils against dermatophyte, Aspergillus and Candida strains. Journal of Applied Microbiology. 100 (6), 1333-1338.

Derwich, E., Benziane, Z., Taouli, R., Senhaji, O., Touzani, M., 2010. A comparative study of the chemical composition of the leaves volatile oil of Juniperus phoenicea and Junipeus oxycedrus. Middle-East J. Sci. Res. 5 (5), 416-424.

Derwich, E., Chabir, R., 2011. Identification of the volatile constituents of the essential oil of Juniperus oxycedrus (Cupressaceae) from the north centre region of Morocco. Asian J Pharm Clin Res. 4 (1), 50-54.

Dob, T., Dahmane, D., Chelghoum, C., 2006. Essential oil composition of Juniperus oxycedrus growing in Algeria. Pharmaceutical Biology. 44 (1), 1-6.
Ismail, A., Lamia, H., Mohsen, H., Bassem, J., 2011. Chemical composition of Juniperus oxycedrus L. subsp. macrocarpa essential oil and study of their herbicidal effects on germination and seedling growth of weeds. Asian J. App. Sci. 4 (8), 771-779.

Lamnauer, D., 2005. A Guide to Medicinal Plants in North Africa; IUCN Centre for Mediterranean Cooperation Malaga, pp.157-158.

Loizzo, M.R., Saab, A.M., Tundis, R., Statti, G.A., Menichini, F., Lampronti, I., Gambari, R., Cinatl, J., Doerr, H.W., 2008. Phytochemical analysis and in vitro antiviral activities of the essential oils of seven Lebanon species. Chen Biodivers.5 (3), 461-470.

Medini, H., Elaissi, A., Khouja, M.L., Chraief, I., Farhat, F., Hammami, M., Chemli, R., Harzallah-Skhiri, F., 2010. Leaf essential oil of Juniperus oxycedrus L. (Cupressaceae) harvested in northern Tunisia: composition and intra-specific variability. Chem Biodivers. 7 (5), 1254-1266.

Medini, H., Elaissi, A., Khouja, M.L., Piras, A., Porcedda, S., Falconieri, D., Marongiu, Farhat, F., Chemli, R., 2012. Chemical composition of the essential oils of the berries of Juniperus oxycedrus L. ssp. rufescens (L. K.) and Juniperus oxycedrus L. ssp. macrocarpa (S. \& m.) Ball. and their antioxidant activities. Natural Product Research. 26 (9), 810-820.

Micevski, K., 1985. Flora na R. Makedonija. $1^{\text {st }}$ Ed. Makedonska Akademija na Naukite i Umetnostite, Skopje. pp. 81-84.

Salido, S., Altarejos, J., Nogueras, M., Sánchez, A., Pannecouque, C., Witvrouw, M., De Clercq, E., 2002. Chemical studies of essential oils of Juniperus oxycedrus ssp. Badia. Journal Of Ethnopharmacology. 81, 129-134.

Stassi, V., Verykokidou, E., Loukis, A., Harvala, C., Philianos, S., 1996. The antimicrobial activity of the essential oils of four Juniperus species growing wild in Greece. Flavour and Fragrance Journal. 11(1), 71-74.

Stassi, V., Verykokidou, E., Loukis, A., Harvala, A., Philianos, S., 1995. Essential Oil of Juniperus oxycedrus L. subsp. macrocarpa (Sm.) Ball.. Journal of Essential Oil Research. 7 (6), 675-676.

Velasco-Negueruela, A., Perez-Alonso, M.J., Pala-Paul, J., Inigo, A., Cervera, M., Lopez, G., 2003. Essential oil analysis of the leaves and berries of Juniperus oxycedrus L. subsp. badia (H. Gay) Deneaux. Botanica Complutensis. 27, 147-154.

Tumen, I., Suntar, I., Keles, H., Akkol, E.K., 2012. A Therapeutic Approach for Wound Healing by Using Essential Oils of Cupressus and Juniperus Species Growing in Turkey. Evidence Based Complementary and Alternative Medicine, Article ID 728281. 
Резиме

\title{
Хемиски состав и антимикробна активност на етерично масло од бобинки од диворастечка црвена смрека Juniperus oxycedrus L. (Cupressaceae) од Р. Македонија
}

\author{
Флореша Села ${ }^{1}$, Марија Карапанџова ${ }^{1 *}$, Ѓше Стефков ${ }^{1}$, Ивана Цветковиќ ${ }^{1}$, \\ Елена Трајковска-Докиќ ${ }^{2}$ Ана Кафтанџиева ${ }^{2}$, Светлана Кулеванова ${ }^{1}$

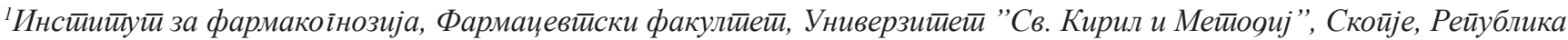 \\ Макеоонија

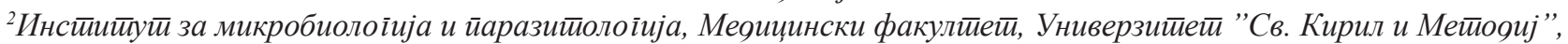 \\ Скойје, Рейублика Макеоонија
}

Клучни зборови: Juniperus oxycedrus, етерично масло од бобинки, состав на етерично масло, GC/FID/MS, антимикробна активност.

Хемискиот состав и антимикробната активност се испитувани на 2 различни примероци на етерично масло од бобинки од диворастечкиот Juniperus oxycedrus L. (Cupressaceae) од Република Македонија. Co GC/FID/MS анализа, идентификувани се 100 компоненти и истите сочинуваат 96,00-98,95 \% од маслото. Најзастапените компоненти во маслото се $\alpha$-пинен (22,54-27,12 $\%)$, мирцен $(11,26-15,13 \%)$ и лимонен $(2,78-18,06$ \%). Антимикробната активност на етеричните масла е испитувана со диск дифузиона и диск дилуциона метода на 16 бактериски изолати на Грам позитивни и Грам негативни бактерии и еден изолат на габата Candida albicans. Најголема осетливост на дејството на маслата покажа бактеријата Haemophilus influenzae (MIC=125 $\mu 1 /$ $\mathrm{ml}$ ). Етеричните масла покажаа умерена антимикробна активност кон Streptococcus pneumoniae, Staphylococcus aureus, Streptococcus agalactiae, Streptococcus pyogenes, Corynebacterium spp., Escherichia coli и Campilobacter jejuni (MIC> $500 \mu 1 / \mathrm{ml})$. Етеричните масла не покажаа активност кон Candida albicans, Staphylococcus epidermidis, Acinetobacter spp., Salmonella enteritidis, Shigella flexnery, Klebsiella pneumonia, Pseudomonas aeruginosa, Enterococcus и Proteus mirabilis. 


\title{
Medical device risk management and its economic impact
}

\author{
Katerina Krsteva Jakimovska ${ }^{1 *}$, Marija Glavas-Dodov², Jasmina Tonic-Ribarska², \\ Suzana Trajkovic-Jolevska \\ ${ }^{1}$ Promedika DOOEL, Skopje, Macedonia \\ ${ }^{2}$ Faculty of Pharmacy, University Ss. Cyril and Methodius in Skopje, Macedonia
}

Received: September 2013; Accepted: October 2013

\begin{abstract}
The importance of medical devices in everyday users/patients lives is imensse. This is the reason why emphasis must be put on safety during their use. Satisfactory safety level can be achived by implementation of quality and risk management standards. Medical device manufacturers must learn to deal with the potential risks by using theoretical and practical examples and measures in order to protect their users/patients and themselves from suffering huge losses arising from adverse events or recall of their products. The best moment for implementation of risk management methods and analysis begins from the device design and development through manufacturing, sales and distribution. These way medical device manufacturers will succseed in protecting their users/patients from serious adverse events and at the same time protect their brand and society status, while minimizing economic losses.
\end{abstract}

Key words: medical device, risk management, adverse events, medical device market, risk-benefit.

\section{Introduction}

Medical devices are vital and integral part of the healthcare system. They have an enormous impact on everyday life quality of all users/patients. Because of this, their safety, quality and efficacy must be assured.

Medical device safety can be viewed by using relative terms. All devices carry certain risk level and during certain circumstances can cause a problem/adverse event. Most of the problems that appear cannot be detected until the medical device is placed on the market and actually used by a patient/user. For example, an implant can show a problem that was not predicted at the moment of implantation. The problem can represent a state that appears only in certain special patients. Some medical devices can experience problem with its consisting components. Yet, some of the problems that appear can be detected so early, for example, during the design phase. Because of this, it is

\footnotetext{
* krsteva_k@promedika.com.mk
}

recommended that risk management processes are applied during the entire life-cycle of the medical device.

\section{Risk and medical device risk management}

The term risk, as defined in WebFinance Bussiness dictionary (Webfinance, 2014), represents a probability or a threat by a hazard, loss or other negative occurrence triggered by external or internal vulnerabilities that can be neutralized by forward taken activities.

The medical device safety approach is consisted of; assessing the potential of the medical device to cause a hazard resulting in safety problems and danger to the patient/user. This is referred to the term risk assessment.

By other means, the term hazard represents the potential for a medical device to show certain adverse event or to represent a source of danger. The term risk refers to a measure for the combination of hazard, the possibility for occurrence of adverse event and the seriousness of the entire event. 
Medical devices cause hazard only if there is sequenced occurrence of events that result in hazard situation. The event sequence may include one event or a combination of events. Hazard situation appears when users/patients or the environment are exposed to hazard. But it must be underlined that a hazard situation may appear even when no visible mistakes exist. In cases when hazard situations occur because of a mistake, the probability of the mistake is not the same as the probability of a hazard occurrence. Mistakes may not always result in hazard situations, and the hazard situations may not always result in hazard.

The risk management goal is to maximize the benefit of the medical device use and minimize the risk occurrence during their use.

In everyday practice, medical device manufacturers have to strive for obliged incorporation and proper use of the Quality Management System (QMS) and Risk Management System (RMS). This is to be done for one and only reason and that is insuring safer products for the patients/users. During the last few years we are witnessing more and more medical device recalls. This is the reason why authorities strive for more demanding requests on incorporation of these standards in the processes of development, design, manufacturing, distribution (the whole life cycle of the medical device). These two systems can exist on their own, but they can be incorporated one into another and this way they would reduce expenses and improve efficacy.

The international standard ISO 13485:2012 represents a system that specifies the requirements on the quality management where the organization demonstrates its ability to assure medical devices that encounter both the regulatory and customer needs. Effective QMS is essential for assuring safety and good performance of the medical devices. Good defined QMS includes safety issues on different specific areas. Knowing the importance of device safety is useful to identify some safety activities that specially imply on safety issues and assure proper input and fitback from the unique activities to QMS.

The degree that the safety issues are analyzed should be adequate to the degree of the risk and the nature of the medical device. Some of the medical devices have low risks or well known risks, and eventually some of the devices represent the state of the art and their risks are still not known and are about to be discovered.

The risk management principles should apply during the entire medical device life-cycle and they should be used identifying and addressing the safety issues. Risk management represents an important part of effective system for assuring quality and safety, and the reason for this is that decision making should be documented on the risk basis. The risk is usually evaluated in two perspectives: safety risks and business risks.

ISO 14971:2007 represents a second edition and it substitutes the edition issued in year 2000 ISO 14971:2000. At the same time it substitudes Annex 1 from this edition
(ISO 14971:2000/Amd 1:2003). The second edition was issued in 2007, and in 2012 was issued ISO 14971:2012 that serves as updated 2007 edition.

This international standard provides system where the experience, clear point of view and judgement are applied systematically in order to manage the risks related to medical device use. This system was specially developed for medical device manufacturers that use principles based on risk management. For all other participants for example, the ones from the health industry, this standard can be used as informative guidance in the development and maintenance of the system and the risk management processes. This standard manages the risk management processes primarily to patient/user, but also to the operator, other equipment and the environment.

Generally, in all activities where the organization or the individual are included they can expose themselves or the other stakeholders to hazard that can cause a loss or harm of their values. Risk management is a complex matter because every stakeholder sets different value on the opportunity to the harm occurring and its seriousness.

All stakeholders, must understand, that medical device use involves certain degree of risk. Risk acceptability depents on various components important for the stakeholder. To make a decision for a medical device to be used in certain clinical procedure needs all residual risks to be balanced against expected benefits. These decisions can be made only by qualified medical personal that has abundant knowledge of the patient's health or the patient himself.

As part of all stakeholders, the manufacturer makes decisions about the medial device safety, including the risk acceptability. The only goal of these complex decisions is to put a safe medical device on the market, with a proper use. ISO 14971 has specific procees that provide every manyfacturer with techniques to identify all hazards related to the medical device. These processes also help to asses and evaluate the risks related to these hazards, to control and monitor the effectiveness of these hazards. The requirements from this standard have their own application in every stage of the medical device life cycle.

The risk management is defined as the probability for the harm to arise and the concequences from this harm, or how dangerous can it be. The manufacturer must consider this definition and than apply the processes of:

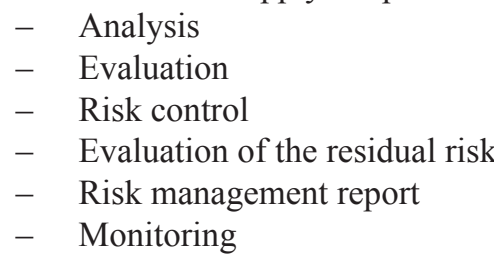

In this way manufacturers identify the possible hazards and hazard situations and demonstrate that the exsisting risk is minimized and brought to an exceptable level.

Once the characteristics of the medical device are identified, the risk assessment process can begin. At first

Maced. pharm. bull., $59(1,2) 49$ - 60 (2013) 
Table 1. Medical device global sales per year (in billion dollars)*

\begin{tabular}{lccccc}
\hline \hline Region & 2009 & 2010 & 2011 & 2012 & 2013 \\
\hline America & 102.4 & 107.1 & 112.1 & 117.4 & 122.8 \\
Western Europe & 62.3 & 66.7 & 71.6 & 76.9 & 82.5 \\
Asia/Pacific & 42.5 & 46.1 & 49.9 & 54.3 & 58.9 \\
Central/Eastern Europe & 10.3 & 11.3 & 12.4 & 13.6 & 14.8 \\
Africa/Middle East & 5.7 & 6.0 & 6.3 & 6.7 & 7.0 \\
Total & 223.2 & 237.2 & 252.3 & 268.9 & 286.0 \\
\hline
\end{tabular}

*Source: Medical Market Fact Book, 2008

hazard identification is made and then evaluation and other actions are taken to make the risks acceptable. All action taken need to be re-evaluated to assure that the risk is minimized to a certain level and no additional risks are created (Dumbrique, 2010).

From above can be concluded that ISO 14971 standard provides manufacturers with risk management frame procedures that are related to the medical device usage. This way the manufacturer can easily identify, asses, evaluate and control the risks and monitor its effectiveness.

\section{Medical device market}

The main reason for medical device growth (both manufacturing and sales) is the incrised requirements and needs by the population that reaches its 50 and 60 (so called baby boomers). This population wants to maintain its vitality as long as possible. So, manufacturers continue to research new ways for growth, development and satisfaction of the needs pointed by the potential buyers.

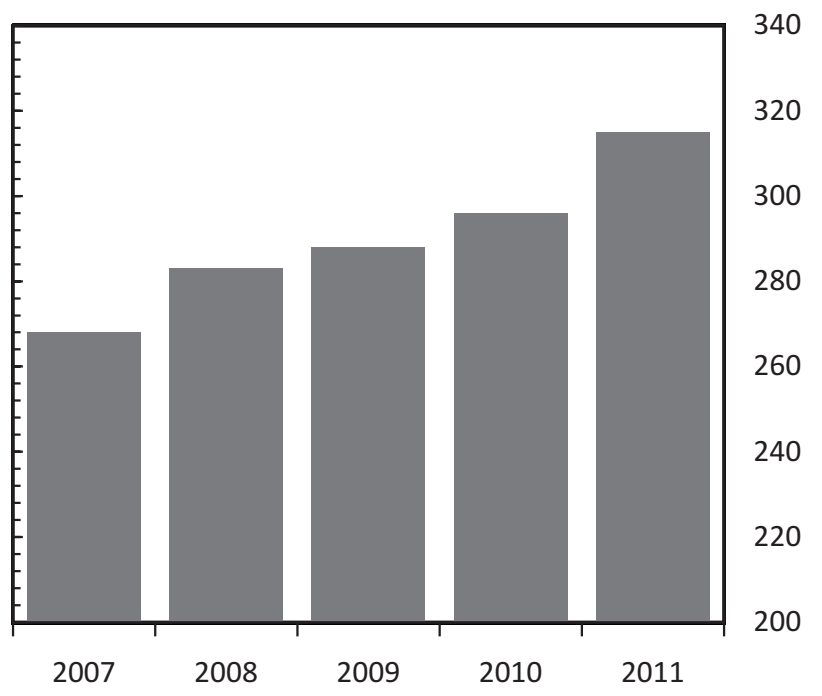

Fig. 1. Medical device market revenue history (USD) (adapted from http://www.slideshare.net/ FrostandSullivan/european-medical-devicesindustry-assessment-a-symptomatic-evaluation).
The Gross Domestic Product (GDP) in Europe is aproximatly 1 trilion euros. Every year, $8.7 \%$ of the European GDP are spent for health care, and $6.3 \%$ (63 bilion euros) from this amount are spent on medical devices that derive from the European market. This represents 0.5$0.6 \%$ from the entire European GDP. Medical devices global sales are shown on Table 1.

According to the Frost and Sulivan report (Praveen, S.M., 2012), which demonstrates hronological review of the world medical device market (Fig. 1), conclusion can be easily reached. It can be seen the continous growth of the rewenues that companies made in this field.

As it can be seen, in 2013 global sales of medical devices is expected to be 286 billion dollars. Approximatelly 123 billion dollars originate from USA market, approximately 100 billion dollars originate from European market (western European and central/eastern European), while 60 billion dollars from the Asia/Pacific (Japanise) market.

In the near future it is expected that the medical device market will continue to grow above average. It is expected that by 2015 the medical device market will have annual growth of 7\% (Reportlinker, 2014). However, the USA medical device market remains to be the lider with greater volume, and the reason for this is the presence of the innovation and foreward technology. The main driving force for this above average growth is the increased number of the population in the development countries that reaches deep ages and the strong position for export of the medical devices in the European industry. USA, Europe, Japan and Canada markets are exteremely big markets, but at the same time they are ripe markets that have stable and relatively low yearly growth rate of the demand and compsumption of medical devices. This is the reason why medical device manufacturers have to seek new alternative markets to ensure its further growth. So, in the near future out of great importance will be the export of the medical devices in the fast growing and over populated countries like China and India, where cheap work force is available (Zimmermann, 2008). 


\section{Adverse event trend and medical device recalls}

Reacently, more and more patients/users experience adverse events that arise from the medical device use. Investigations are made for better understanding the reasons for the gaps in quality and safety. These investigations reveal exsistence of systematic gaps in the manufacturer and industry quality approach.

In the last 10 to 20 years, medical device industry enjoys great growth both in revenues and technology complexity. It was noted that serious adverse event reports associated with the use of medical devices exceeds the growth of $8 \%$ per annum calculated from 2001 until today. Thereby provided 'root cause' analysis reveals that failures in the product design and production process control itself constitute the main reason for more than half market withdrawals. Results have not met the common thought that the main reason for product withdrawal is found in the therapeutic area range.

Between 2001 and 2009, reported side effects have increased approximatelly $15 \%$ per year, i.e. from 57,000 report adverse effects in 2001 to more than 207,000 reported side effects in 2009. From 2005 to 2009 the rate of reported side effects has significantly risen to $19 \%$ annually. The emerge of serious side effects with the obtained resultsdeath, life-threatening, disability or hospitalization rose $17 \%$, from 8000 in 2002 to 28,000 in 2009. During this period the USA medical devices market profit doubled in size. Although the extent of this growth and the occurrence of adverse events are controlled, adverse event reports grew at a rate of $8 \%$ per year, with a sharp increase of $14 \%$ per year starting from 2005 till 2009.

Several factors contribute to the growth of the adverse events. These factors include increased requirements for reporting adverse events which are given on the recommendation of the FDA, which is accompanied by increased sensitivity of producers to these requirements. Part of this growth is a result of the growth in the number of medical devices that are used.

Growth of the number of recalls increases at a lower rate than the growth in the number of adverse events, but also it is determined that their growth is in line with the growing industry of medical devices. In 2003540 recalls were registered, and by 2009 this number increased to 763 , at an annual rate of $6 \%$. Divided by classes, Class 2 medical take up to $80 \%$, followed by Class 3 devices taking around $15 \%$ of recalls.

The increased growth of the adverse events carried out by the devices is attributed to the medical devices that are responsible for life sustaining, but the same it does not refer to the increased number of recalls. In 2003, 27\% of the adverse events accounted for Class III medical devices, by 2009 this figure increased to $40 \%$. Consequently, class III medical device recalls are reduced from $17 \%$ of total withdrawal in 2003 , to $7 \%$ in 2009 . The decreased number of medical device recalls in class III devices is a direct result from implementation of the risk management proceses by the manufacturers of medical devices.

The risk of adverse events is not uniformly distributed within the industry of medical devices. Certain therapeutic areas show a larger share of appearance of adverse events. The research adopted the conclusion that the medical devices in the areas: cardiovascular, IVD, surgical instruments (in comparison with 13 other therapeutic areas) make usp the largest number of reported adverse events. These three therapeutic areas make up the majority of total reported adverse events - and that share is $6 \%$.

With systematic root causes analysis of the medical device quality, it has been established that there are 36 main reasons for beginning a recall procedure. The reason for recall can be found in the area of design, supply, manufacturing, production and change, and the cause for the recall might be the hardware, software, labelling, packaging, procees or regulation. During this surway it was determined that almost one third of total recall $(\mathrm{N}=4391)$ was due to errors in the design area (around 31\% of all recalls), and the remaining quarter is a result of problems in the manufacturing process (around 24\% of all recalls). As a surprise was the fact that only $12 \%$ of all recalls was in the postproduction area (FDA, 2011).

\section{Quality economy}

It must be emphasized that the quality economy changes through the years. In the past, when the products were placed on the market in the early stages of development, it meant that the use of the medical device in its early stages is much more cost approved, than the costs ocurred as a result of a high level of quality and reliability absence. But this is no longer the case and there are three major reasons for that:

- Increase of the risk for failure deriving from the product quality - the increased complexity of medical devices and the complexity of the user environment, simultaneously increased the likelihood of significant adverse events in terms of quality

- Increasing costs as a result of failure in the quality - costs resulting from adverse events in the field of quality in medical devices have increased as a result of increased attention by regulatory, legal bodies and the media. Fig. 2 shows the average drop in the share price of companies which can be seen to be quite significant and increased in the last decade. Fig. 3 shows a few recent examples of events in the area of quality that quite raised the costs (exspences) for the manufacturers.

- Increased transparency and its conversion into quality- Trend leading to research on the comparative effectiveness of medical devices will provide increased visibility of their quality 
and performance. Comparisons of therapeutic opportunities in medical devices will raise the quality and safety of specific medical devices. The formation of databases that would gather data on adverse effects through public-private collaboration is expected to lead into increased alertness and awareness of adverse effects and defects in medical devices.

\section{Overcomming risks by using experience analysis}

Medical device manufacturers are faced daily with enormous risks deriving from regulatory, legal and financial nature. It was determined that risks result from the manufacturers' production line and operational processes that were used in the manufacturing process. Risks may have a wide range. They may represent small disturbances in the operational functions, up to loss of consumer trust and the brand confidence.

It was concluded that companies that enjoy growth in profits and turnover, understand that their success is conceived on the base of things that their customers appreciate, such as:

- Product quality and innovation,

- Brand and reputation,

- User support and

- Flexibility.

These types of companies have more formal processes that foster teamwork between departments and colleagues.

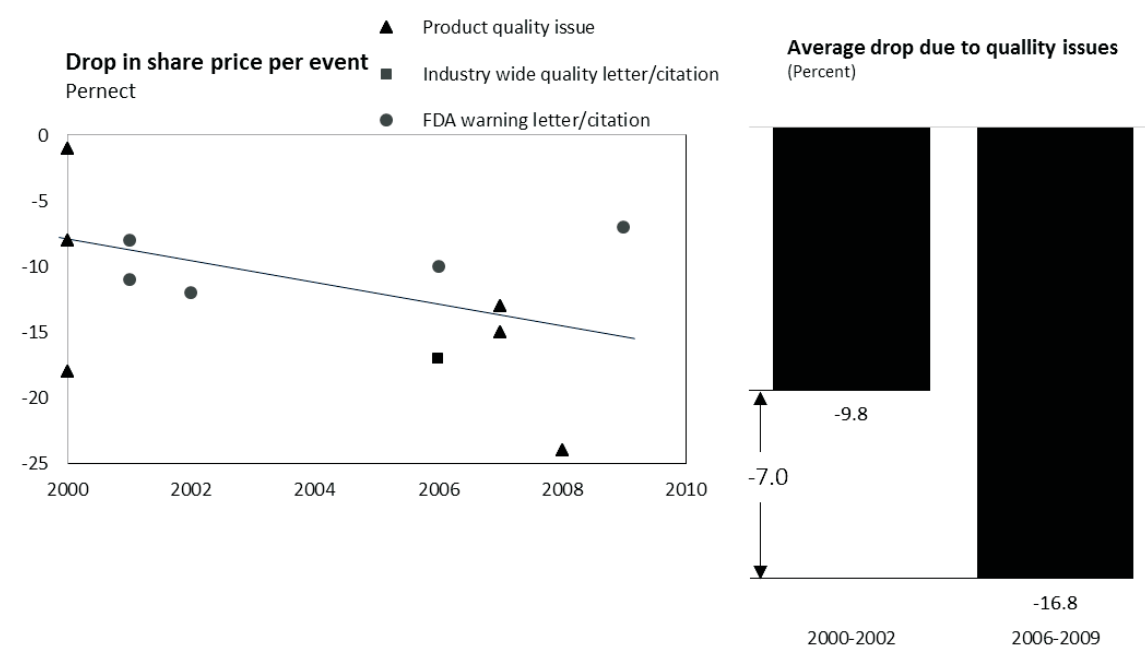

Fig. 2. Size and trends in medical device company share price drops following specific major quality events (FDA, 2011).

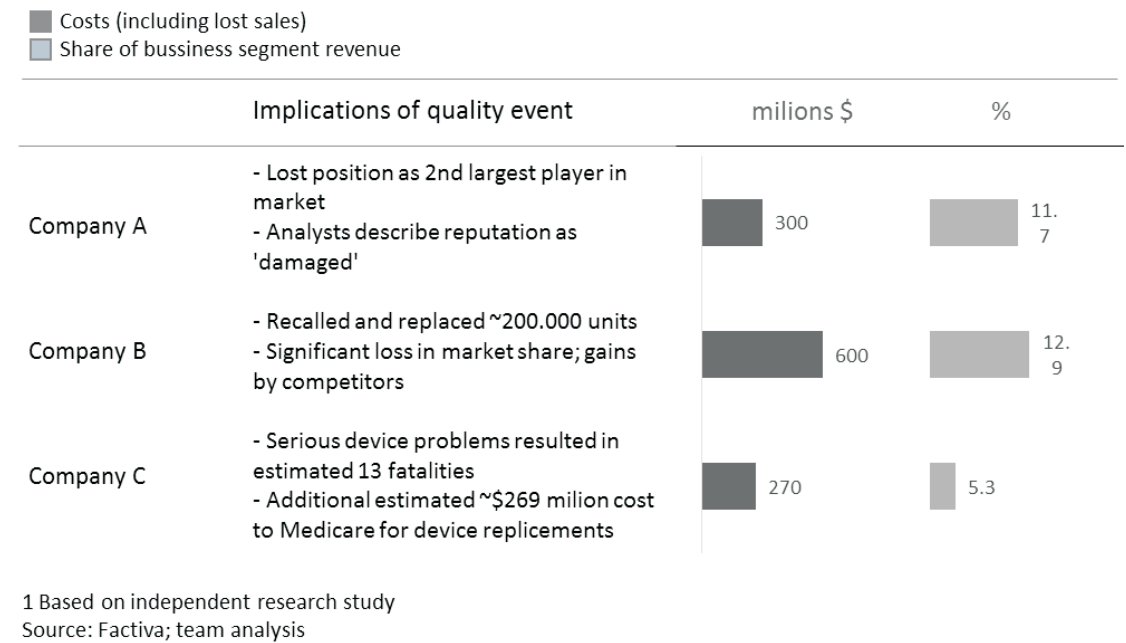

Fig. 3. Examples about the financial impact on the selected quality event incidents. 
That way they can easily overcome potential risks.

The survey (http://www.ptc.com, 2008) found out that although nearly all companies are focused on risk management processes and analysis, implemented processes and practices may be incomplete. Some of the weaknesses of risk management processes include poorly managed product development, poor cooperation between sectors, incomplete risk analysis, incomplete or lack of root cause analysis, inconsistent information and manually processed documents. From here it becomes clear how risks are created for users/patients and business success.

Risk management can take many forms. The most obvious view of the risk management process includes risk for patients who use the medical device and from this point of view the risk to the business. Theoreticaly the risk management process ensures patient safety and it is supposed to reduce the overall risk and contribute to a greater likelihood of profit.

Many of the medical device manufacturers made clear that the processes used to meet regulatory requirements and validation cause constraints in the business. In fact many of the manufacturers feel pressured by regulatory bodies. Manufacturers stated that they constantly needed to teach the latest technologies and regulatory bodies have the impression that they constantly play the role of police. Working under pressure leads to more opportunities for oversight.

The biggest challenge for the large number of manufacturers is the ability to see the overall picture of the company and linking factors through products, departments and premises to the actual risks and thus effectively overcoming the risks for patients and business. Manufacturers describe some strengths and weaknesses in their approaches to risk management (Table 2).

It is also believed that the competitiveness and volume growth represent areas that can contribute to occurrence of potentially increased levels of risk. Adopting new technologies and innovation can also represent a source of risk. However, it must be noted that risks lead to increased profits, but also can lead to a huge loss if not controlled, especially in the early stages of design and development.
The question is where the manufacturer of medical device should invest in order to overcome the risks. On one side, it is believed that special attention should be paid to research and development approaches focused on innovation, and on the other hand attention should be paid to the risk management and all the necessary analysis, as well. Also it is agreed that the timely planning, design and similar efforts contribute to reducing the risk, rather than actions taken when a problem arises.

So, it can be concluded that out of enormous importance is the cooperation and information flow between departments within the companies. Lack of cooperation can lead to increased overall risk. Most of the companies store the informations and data in paper form, eventhough they believe that these data are difficult to obtain. The data can be inaccurate and its reassessment can only slow down the overall process. For this reason most helpful is the implementation of software systems as a program resource planning, electronic document management system, supply chain management system, supplier relationship management. In order to fully use the software companies need to integrate applications that provide data stream. As they experience greater growth and complexity of the products, the explosion of information management will be more difficult without the use of appropriate software.

Medical device manufacturers have a huge opportunity for growth and profit. But this growth contributes to increasing complexity and risk. It can be concluded that risk management is a critical issue for manufacturers of medical devices. Manufacturers increasingly understand that reducing the risk to patients, assists in reducing the business risk (FDA, 2011).

\section{Risk-benefit analysis}

The risk-benefit analysis is not necessary to be performed by the manufacturer for each and every risk. This analysis is used to justify a particular risk in case when all practical risk reduction measures were applied. If the risk has not been judged as acceptable after the application of these measures, it is necessary to obtain risk-benefit

Table 2. Areas of strengths and weaknesess amnog manufacturers of medical devices

\begin{tabular}{ll}
\hline \hline \multicolumn{1}{c}{ Strenghts } & \multicolumn{1}{c}{ Weeknesses } \\
\hline $\begin{array}{l}\text { Consistent and aligned risk-based analysis for all areas with } \\
\text { lifecycle approach }\end{array}$ & $\begin{array}{l}\text { Isolated departments working with piecemeal software that does } \\
\text { not foster teamwork } \\
\text { Constantly improving standards }\end{array}$ \\
$\begin{array}{l}\text { Cound process\&mindset at early concept phase to stop or push sigma } \\
\text { projects by analysis }\end{array}$ & $\begin{array}{l}\text { Postmarket surveillance does not feed prevention at concept stage } \\
\text { Root cause analysis\&trending for re-occurence }\end{array}$ \\
$\begin{array}{l}\text { sit on standards committeesto stay in front of practices } \\
\text { Clinician staff \& QMS software for complaints }\end{array}$ & \begin{tabular}{l} 
Regulatory affairs views all change as risk \\
\hline
\end{tabular}
\end{tabular}


analysis in order to determine whether a medical device will provide more benefit than harm.

Generally, if all practical control measures are insufficient to meet the criteria for acceptability of risk in the risk management plan, the design of the medical devices needs to be abandoned. But, in some cases the major risks can be justified if they exceed the expected benefits from the use of the device. The decision whether the risks outweigh the use is essential work decision by experienced individuals with greater knowledge. Further risk reduction is necessary to take into account before evaluating the benefits. Unfortunately, there is no standardized approach for assessing benefits, and it should be done usin case by case approach.

\section{Benefits Assessments}

The benefits of the medical device use are related to the probability of emergence and continuous improvement of health which is expected. The benefits can be estimated from the following:

- The performance expected during clinical use

- Expected result from the clinical performance

- Factors that are out of importance to the risks and benefits from other possible treatments

The assessment of usefulness is heavily dependent on the reliability of the evidence relating to these factors.

This includes recognizing the possibility of the existence of possible outcomes and factors, as listed below, which is necessary to take into account:

- It is difficult to compare different results, such as what is worse, the pain or the loss of mobility? From the side effects you can get different results which can greatly differ from the initial problem.

- It also involves not stable outcomes. They may arise from the time it takes for recovery and long-term effects.

Due to difficulty of having a rigorous approach, it is generally acquired compsumptions to be simplified. For this reason, most effective way is to put focus on the most common results for each option.

Assessment of the clinical benefit may vary at different stages of the design cycle of a medical device. If available clinical data show constant performance and effectiveness of the product, the clinical benefit can be estimated. In cases where clinical data are with limited quality and quantity, benefits are estimated with greater uncertainty.

For example, sometimes it is necessary to estimate the expected level of health improvement in early stages, but in apsense of relevant clinical data likelihood of achieving the required performance and the desired clinical effect will have to be provided by reference measures for ensuring quality as well as in vitro and in vivo performance characteristics.

Where significant risks are present and there is a high degree of uncertainty in the assessment of the benefits, the expected performance or efficiency may soon be confirmed by surrogate study or clinical trial.

All of this is necessary to determine that the riskbenefit balance is as expected and prevents unwanted exposure of patients to a residual risk.

\section{Criteria for assessing the risk-benefit}

Those who are involved in risk-benefit decision making have a responsibility to understand and take into account the technical, clinical, regulatory, economic, social and political influences that relate to their decisions. This may include interpretation of the requirements set out in regulations and standards applicable to the product under expected conditions of use. Since this type of analysis is highly product-specific, a general guide for further use is impossible. Instead, the safety requirements specified by the standards relating to specific products or risks are considered to be coexistent with a certain acceptable level of risk. It should be noted that sometimes clinical trials, in accordance with the legally recognized procedures, could be required, in order to verify that the balance between medical benefit and residual risk is acceptable.

\section{Risk-benefit comparision}

Direct comparison of risks and benefits is valid only if a common scale for comparison is used. When using this type of comparative scale for risk-benefits, quantitative evaluation can be made. Indirect risk-benefit comparison does not use a general scale and and is not evaluated qualitatively. Whether qualitative or quantitative comparisons are made, it is necessary to take into account the following facts:

- Initial literature survey for potential hazard class of the product can provide significant insight into the risk-benefit.

- Medical devices with high risk-high benefit ratio usually represent the best access technology that provides medical benefits, but does not eliminate completely the risk of injury or illness. For this reason, understanding the current technology that relates to medical practice is required to perform an accurate riskbenefit analysis.

- In order to perform validation for acceptable risk-benefit criteria, it is necessary to perform clinical testing. Clinical testing can quantify the use and risks. Also, through clinical trials 
the acceptability to the society (patients, consumers and medical staff) can be examined.

- Labels for devices with high risk-high benefit should contain relevant information for users, patients and medical staff in order to provide risk-benefit to individuals immediately prior to use of the device

- Medical devices with high risk-high benefit have additional regulatory requirements that need to be met before being placed on the market

- Prior to launch a new or revised product that required a risk-benefit analysis, the manufacturer should summarize the available information related to the determination of risk-benefit and to document these findings.

As a summary, if the residual risk is found to be unacceptable using the criteria set out in the risk management plan and if further risk control measures are not applicable, the manufacturer has to collect and review data and literature to determine whether the medical device use overweights the remaining risks. If these data do not support the conclusion that the medical device use overweight residual risks, the risk remains unacceptable. For the risks that is demonstrated that overcome the benefits of use, the manufacturer has to decide which security information is necessary to be given for the purpose of revealing the residual risk.

\section{Duty to warn (labeling)}

Duty to warn applies to all reasonably foreseeable risks of use and abuse of the medical device, the method of storage, storage/cleaning and disposal of the product. Liability arises if warning marks are unsuccessful or inadequate.

Warning labeling covers specific risks and provides instructions that describe how to avoid risks or how to facilitate other ways to overcome the risk. The purpose of the warning is to inform the user how to behave in a way to avoid injury.

Adequate warning (position labeling/leaflet, specificity of risk, intensity language) should be noticeable, understood and with the appropriate intensity level. Detectable designations are very important because the product can be properly designed and manufactured, but will pose a risk in the absence of warning or absence of proper risk communication.

The duty to warn can be defined as: a reasonable person would want to be warned.

The manufacturer has an obligation for post-sale duty to warn because some hidden risks become apparent after the distribution and market sale. Post-sale duty to warn includes a duty to monitor the changes in technology complaints and post production risks monitoring.

It is generally accepted that the manufacturer knows

Table 3. Review to the manufacturers quality and values*

\begin{tabular}{|c|c|c|c|}
\hline \multirow{2}{*}{ Value stream steps } & \multicolumn{3}{|c|}{ Quality } \\
\hline & Operating system & Management infrastructure & Mindset \& behaviours \\
\hline $\begin{array}{l}\text { Product/process } \\
\text { design }\end{array}$ & $\begin{array}{l}\text { "The way value streams and } \\
\text { resouces are configured and } \\
\text { optimized for safe and timely } \\
\text { delivery of customer demand at } \\
\text { lowest lifecycle cost" }\end{array}$ & $\begin{array}{l}\text { "The formal structure processes, } \\
\text { and systems through which the } \\
\text { operating system is managed to } \\
\text { deliver the business objectives" }\end{array}$ & $\begin{array}{l}\text { "The way people think, feel, } \\
\text { and conduct themselves in the } \\
\text { workplace, both individually } \\
\text { and collectively" }\end{array}$ \\
\hline Supplier management & $\begin{array}{l}\text { - Continuous flow of materal and } \\
\text { information throughout value stream } \\
\text { - Institution of standard operating } \\
\text { procedures for each process stop } \\
\text { focusing on value-added } \\
\text { - Scheduling of capacity to meet } \\
\text { demand }\end{array}$ & $\begin{array}{l}\text { - Performance management } \\
\text { including Key Performance } \\
\text { Indicators (KPIs), metrics, target } \\
\text { setting, reporting, and monitoring } \\
\text { - Talent management/HR including } \\
\text { clear roles, responsibilities, and } \\
\text { accountabilities }\end{array}$ & $\begin{array}{l}\text { - Leadership alignment and role- } \\
\text { modeling } \\
\text { - Clear direction and compelling } \\
\text { purpose } \\
\text {-Discipline, collaboration, and } \\
\text { trust }\end{array}$ \\
\hline Manufacturing & $\begin{array}{l}\text { - Focus is on eliminating waste, } \\
\text { variability, and inflexibility }\end{array}$ & $\begin{array}{l}\text { - Organization design (e.g. aligning } \\
\text { the organization with the value } \\
\text { stream) }\end{array}$ & $\begin{array}{l}\text { - Conformance to internal } \\
\text { quality guidelines (e.g. SOPs) }\end{array}$ \\
\hline $\begin{array}{l}\text { Post-production } \\
\text { activities }\end{array}$ & $\begin{array}{l}\text { - Implementating learnings from } \\
\text { market feedback }\end{array}$ & - Monitoring market feedback & $\begin{array}{l}\text { - Continuous-improvement and } \\
\text { quality mindset }\end{array}$ \\
\hline
\end{tabular}

*adapted from http://www.ptc.com/WCMS/files/141876/en/RiskManagementMedDevStudyReporFinal.pdf 
or should have known the potential or existing risks, but sometitemes there is not need to warn if the danger was obvious or generally known by the general public.

\section{Opportunities and recommendations for improving the quality within the industry of medical devices}

Within the medical device industry there are several areas that have potential to improve quality assurance and risk reduction. These steps in the system of values are divided into three domains operating system, infrastructure and management thinking and behavior.

Operating systems include the ways for configurating product performance and optimize systems in an efficient manner. Infrastructure refers to the formal management structures, processes and systems through which operating system is mannaged to achieve the business goals. The way of thinking and behavior, describe how the employees think, feel and behave on their jobs (Table 3).

There are several best practises that can be used by the manufacturers in order appropriately to design and validate the requests for the medical device use. Some companies use formal statistcs tools for translating the user requests in excact technical specifications. Other companies use discusions, advises, expert recommendations and leading clinical experts to achieve the same goal.

Many manufacturers use software programs that do not follow the latest trends, while these programs are used by different users in different applications and environments. Software manufacturers often use inheritance which in some parts is inadequate. The recommendation to manufacturers would be that it is more effective to deal with the design and validation of the software system.

Manufacturers that have mechanisms for monitoring and feedback of the use of medical devices after they are put on the market, are more able to define critical performance parameters in the design of a device that supports the processes and controls of the supplier. Mechanisms also serve as the basis of continuously refining the estimates for the baseline risk assessment of medical devices. Manufacturers can use predictive analysis to build a model to predict the performance of medical devices that will be used prior to its production and marketing, which would additionally be refined on the basis on the actual performance of the medical device.

Companies that manage well their suppliers use several good practices. They carefully select and contact suppliers, with involvement of the internal quality of the organization. That is the way to identify vendors who work with the most critical aspect of their products. These vendors invest in the training of the perssonel and monitoring of the devices. Medical devices companies managing with their suppliers this way are able to stop the cooperation with the suppliers if the quality of the performance decreases.

Manufacturers that have defined quality measures related to medical device design phase, enjoy many benefits. Quality is measured during the design phase, enabling manufacturers to focus their resources on the most critical elements in the value chain especially in the supply quality management. Others indicated that the percaution measures were a key factor in directing effective thoughts to quality in the organization.

Some manufacturers have separated instead of integrating the quality features. So, as a recommendation to the manufacturers would be anyone who is involved in the value chain of the production quality to be obliged to accept ownership.

Integration of a strong culture of quality within the organization is a recommendation for all the manufacurers. All employees need to be bound to respect and promote the quality culture.

\section{Usefull practices and learned lessons as advice for successful medical device risk management}

All described obligations that manufacturer has to carry out during manufacture, distribution and sale of medical devices. Show that risk management is a huge area that must be carefully implemented. Manufacturers can use some of the following practices in the everyday production in order to protect themselves and still manage the risk successfully.

\section{Learning form the contractual and already closed trials}

Practice proved that companies that are divided into sectors and departments, have bad communication between production and quality assurance and very rarely mutually exchange information. In order to oppose this practice it was given an interesting idea; performing the 'root cause' analysis. The root cause analisis presents a thechique of reconstruction of the event that happened, a kind of "autopsy".

Common causes of defects in products, problems or complaints include:

- Giving preference to the finances before the quality of the product (overlooking hidden costs or poor quality)

- Giving priority to scheduled considerations insted to quality considerations

- Raising the level of political considerations over quality matters (internal policies and external marketing)

The purpose of this practice is to learn from past events. It is known from experience that companies often invest in the risk management when serious event occured. But, this should not be the practice if the manufacturers want to protect themselves from unforeseen risks and legal 
proceedings. Therefore, manufacturers should carry out a risk assessment early in the phase of development and design of the product itself) and that obligation must never evade (Quinley, 2007).

Compliance with regulatory requirements as a beginning of the risk management processs - but not as highest level of achievement

Compliance with the regulatory requirements is necessary and obligatory, but not sufficient for good risk management. Companies that have outsourced activities must have strong program compliance in order to protect themselves from fines, jail sentences or lawsuits. Simply following the regulatory rules will not protect the company from product liability. So, even though the manufacturer follows all regulatory rules remains extra duty to take care of the safety of the products - to have products free from errors in design, manufacture and labeling. Manufacturers should implement GMP, but they should serve only as a foundation for further work. Companies need always to strive to overcome and improve all regulatory requirements (Quinley, 2007).

\section{Manufacturers should not make confusion between risk management and purchase of liability insurance}

Possession of liability insurance is part of the risk management process. But, good risk management must go beyond purchasing insurance. Some organizations try to delegate the risk management by purchasing premium insurance. They believe that this way they will resolve the risk, but acctualy they are actting short sighted. Although the purpose of the liability insurance is to recover the losses they had, the company rarely achieves it. Insurance almost always fails to regain the lost business opportunities, reputation, users/patients, staff morale, etc. In fact there is no such insurance that could bear all these costs. Hence, insurance only provides a false sense of security. For this reason, manufacturers need better risk management and they should use liability insurance only as a protection from genuine catastrophic losses (Quinley, 2007).

\section{Conclusion}

From the overall analysis, it can be concluded that the medical device risk management process is not an instantaneous or one-time project. It is an ongoing process, constantly reviewed and assessed over the medical device life-time. Manufacturing companies with serious approach to the process, face fewer defects, as well as increased patient safety.

By reviewing the implementation of safety and quality standards and also the risk management system, greater confidence in the use of the medical device is provided. The introduction of traceability and identification systems also promotes their safety and quality.

But, reacently it was observed that a growing number of patients/users experience adverse effects arising from the medical device use. Surveys showed the existence of systemic gaps in the quality assurance process within the medical device industry.

The 'root cause' analysis revealed that the main reason for more than the half of the market recalls are triggered by failures in product design and process control during production itself, and not, as it was often thought, in the range of the therapeutic area.

The quality economy changed significantly. In the past, when the products were put on market in the early stages of development, it meant that their use is much more profitable than the costs incurred as a result of the absence of a high level quality and reliability.

The risk-benefit analysis is out of great importance since it searves as a warning to the manufacturers about possible risk/benefit issues during device usage. Also it contributes to the completion of the product liability.

The manufacturer is required to promote the postproduction duty to warn, because some hidden risks become visible after the medical device distribution. Postproduction duty to warn also includes the duty to monitor the changes in technology and post-production monitoring of risks.

Furthermore, through practical examples of the ways manufacturers overcome the potential risks to protect their users/patients, some suggestions were given how the manufacturers should learn through personal and competitiors experience.

Finally, it was concluded that the best time to implement the risk management methods and analysis, ranging from the development and design of the device through the production, sales and distribution, in order manufacturers to protect their users/patients of serious side effects and also protect its brand and status in the society while minimizing their economic losses, is the early stage of the medical device design and development.

\section{References}

Dumbrique, R., 2010. Implementation of risk management in the medical device industry. SJSU Scholar Works. San Jose State University, http://scholarworks.sjsu.edu/gen_eng $\mathrm{grad} /$. (Accessed 15 May 2013).

FDA, 2011. Understanding barriers to Medical Device Quality, http://www.fda.gov/downloads/AboutFDA/CentersOffices/ CDRH/CDRHReports/UCM277323.pdf. (Accessed 12 February 2012).

http://www.ptc.com/W CMS/files/141876/en/ RiskManagementMedDevStudyReporFinal.pdf. (Accessed 8 February 2012).

Praveen, S.M., 2012. http://www.slideshare.net/FrostandSullivan/ european-medical-devices-industry-assessment-asymptomatic-evaluation. (Accessed 20 February 2013).

Quinley, K., 2007. Best Practices in product liability Risk Management, MPO Articles. http//www.mpo-mag.com/ 
articles/2007/03/best-practices-in-product-liability-riskmanagemen. (Accessed 5 October 2012).

Reportlinker, 2014. Medical Device Indystry: Market research reports, statistics and analysis www.report linker.com/ Medical-Devices.html. (Accessed 5 April 2013).
WebFinance, 2014. Definition of risk, http://www. businessdictionary.com/definition/risk.html. (Accessed 2 February 2013).

Zimmermann, M., 2008. European Union Medical Device Regulations Summary Report on Guiding Principles, Progeritas.

\title{
Резиме
}

\section{Управување со ризик кај медицински помагала и неговото економско влијание}

\author{
Катерина Крстева Јакимовска ${ }^{1 *}$, Марија Главаш-Додов², Јасмина Тониќ-Рибарска², \\ Сузана Трајковиќ-Јолевска \\ ${ }^{1}$ Промеоика ДООЕЛ, Скойје, Макеоонија

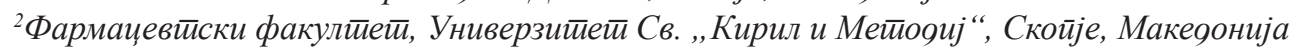

Клучни зборови: Медицинско помагало, управување со ризик, несакани ефекти, пазар на медицински помагала, ризик-корист.

Медицинските помагала имаат огромно значење во секојдневниот живот на корисниците/пациентите. Тоа е основната причина поради која посебно значење се дава на безбедноста при нивната употреба. Задоволително ниво на безбедност при употребата на медицинските помагала може да се постигне со имплементација на стандардите за квалитет и управување со ризик. Производителите на медицински помагала мораат да научат да се справуваат со појавата на потенцијални ризици преку користење на теоретски и практични примери и мерки, а сето тоа да го направат со една единствена цел, да ги заштитат потенцијалните корисници/пациенти, како и себе,од огромни загуби кои би можеле да се појават како резултат на несакани ефекти или отповикувања на нивните производи. Најдобар момент за имплементација на методите и анализите за управување со ризик започнува од моментот на дизајн и развој на медицинското помагало, преку производството, продажбата и дистрибуцијата. На овој начин, производителите на медицински помагала ќе успеат да ги заштитат своите корисници/пациенти од сериозни несакани ефекти и истовремено да го заштитат својот бренд и општествен статус, притоа намалувајќи ги потенцијалните економски загуби. 


\section{INSTRUCTIONS FOR AUTHORS}

Macedonian Pharmaceutical Bulletin is an official publication $\mathrm{f}$ the Macedonian Pharmaceutical Association. The journal publishes original scientific papers, short communications, reviews, mini-reviews and professional papers from all fields of pharmacy and corresponding scientific fields of interest for pharmacy (pharmaceutical and medicinal chemistry, immunology and imunochemistry, molecular biology, pharmaceutical analyses, drug quality control, pharmaceutical technology, pharmacoinformatics, pharmacoeconomics, biopharmacy, pharmacology, applied botany, pharmacognosy, toxicology, clinical pharmacy, food and nutrition, physical pharmacy, organical synthesis, social pharmacy, history of pharmacy etc.)

The Macedonian Pharmaceutical Bulletin, also, publishes and other contributions (recommendations and announcements, reports of meetings, important events and dates, book reviews, various rubrics).

\section{Types of paper}

Original scientific papers (full length manuscripts) should contain own unpublished results of completed original scientific research.

Short communications also should contain completed but briefly presented results of original scientific research. The article should be prepared as described for full length manuscripts, except for the following: the number of pages should not exceed 10 (including 2 illustrations, figures or tables). An Abstract should be included as well as a full reference list.

Reviews and mini-reviews are written at the invitation of the Editorial Board. "Mini-reviews" of a topic are especially welcome.

They should be surveys of the investigations and knowledge of several authors in a given research area, the competency of the authors of the reviews being assured by their own published results.

Professional papers report on useful practical results which are not original but help the results of the original scientific research to be adopted into practical use. Professional papers might be based on the elaborating of theoretical data

\section{Language}

Original scientific papers, short communications, reviews and mini-reviews should be written in good English (American or British usage is accepted, but not a mixture of these), while professional papers and all other contributions may be submitted in Macedonian.

\section{Submission declaration}

Submission of an article implies that the work described has not been published previously (except in the form of an abstract or as part of a published lecture or academic thesis), that it is not under consideration for publication elsewhere, that its publication is approved by all authors and tacitly or explicitly by the responsible authorities where the work was carried out, and that, if accepted, it will not be published elsewhere in the same form, in English or in any other language.

\section{Policy and ethics}

The work described in your article must have been carried out in accordance with The Code of Ethics of the World Medical Association (Declaration of Helsinki) for experiments involving humans http://www.wma.net/ en/30publications/10policies/b3/index.html;

EC Directive 86/609/EEC for animal experiments http:/ec.europa.eu/environment/chemicals/lab animals/ legislation en.htm;

Uniform Requirements for manuscripts submitted to Biomedical journals http://www.icmje.org. This must be stated at an appropriate point in the article.

\section{Submission}

Please submit the manuscript electronically (e-mail address: magl@ff.ukim.edu.mk) as a single PDF file, which will be used in the peer-review process. All correspondence, including notification of the Editor's decision and requests for revision, takes place by e-mail removing the need for a paper trail. 


\section{Referees}

Please submit, with the manuscript, the names, addresses and e-mail addresses of 3 potential referees. Note that the editor retains the sole right to decide whether or not the suggested reviewers are used.

Papers received by the Editorial Board are sent to referees. The suggestions/comments of the referees and Editorial Board are sent to the author(s) for further action. The revised article should be returned to the Editorial Board as soon as possible but in not more than 30 days.

\section{Preparation of manuscripts}

\section{Use of wordprocessing software}

It is important that the file be saved in the native format of the wordprocessor used. The text should be typed (1 $1 / 2$ spaced) on A4 paper with margins of $3.0 \mathrm{~cm}$ on each side in single-column format, font Times New Roman, Mac C Times, Macedonian Times and size 11, Keep the layout of the text as simple as possible. Most formatting codes will be removed and replaced on processing the article. In particular, do not use the wordprocessor's options to justify text or to hyphenate words. However, do use bold face, italics, subscripts, superscripts etc. When preparing tables, if you are using a table grid, use only one grid for each individual table and not a grid for each row. If no grid is used, use tabs, not spaces, to align columns. The electronic text should be prepared in a way very similar to that of conventional manuscripts. To avoid unnecessary errors you are strongly advised to use the "spell-check" and "grammarcheck" functions of your wordprocessor.

The pages in the article should be numbered.

Finally, please create PDF file before sending the article. After acceptance, you will be asked to supply the article as wordprocessing document (zip-file).

\section{Appendices}

If there is more than one appendix, they should be identified as A, B, etc. Formulae and equations in appendices should be given separate numbering: Eq. (A.1), Eq. (A.2), etc.; in a subsequent appendix, Eq. (B.1) and so on. Similarly for tables and figures: Table A.1; Fig. A.1, etc.

\section{Abbreviations}

Define abbreviations that are not standard in this field in a footnote to be placed on the first page of the article. Such abbreviations that are unavoidable in the abstract must be defined at their first mention there, as well as in the footnote. Ensure consistency of abbreviations throughout the article.

\section{Units}

Follow internationally accepted rules and conventions: use the international system of units (SI). If other units are mentioned, please give their equivalent in SI.

The names of substances should be in accordance with the IUPAC recommendations and rules or Chemical $A b$ stracts practice.

\section{Math formulae}

Present simple formulae in the line of normal text where possible and use the solidus (/) instead of a horizontal line for small fractional terms, e.g., $\mathrm{X} / \mathrm{Y}$. In principle, variables are to be presented in italics.

\section{Footnotes}

Footnotes should be used sparingly. Number them consecutively throughout the article, using superscript Arabic numbers. Many wordprocessors build footnotes into the text, and this feature may be used. Should this not be the case, indicate the position of footnotes in the text and present the footnotes themselves separately at the end of the article. Do not include footnotes in the Reference list.

\section{Table footnotes}

Indicate each footnote in a table with a superscript lowercase letter.

\section{Figures}

Figures (photographs, diagrams and sketches) and structural formulae should each be given on a separate sheet (the place to which they belong in the text should be indicated). The figures should be numbered in Arabic numerals (e.g. Fig. 1). Ensure that each illustration has a caption. Supply all captions separately, not attached to the figure. A caption should comprise a brief title (not on the figure itself) and a description of the illustration. Keep text in the illustrations themselves to a minimum but explain all symbols and abbreviations used.

Please submit the pictures in a black and white version.

Tables

The tables should be numbered in Arabic numerals (e.g. Table 1) and each should be given on a separate sheet (the place to which they belong in the text should be indicated). Number tables consecutively in accordance with their appearance in the text. Place footnotes to tables below the table body and indicate them with superscript lowercase letters. Be sparing in the use of tables and ensure that the data presented in the tables are not duplicated elsewhere in the article. 


\section{Article structure}

Manuscript should contain: title, abstract, key words, introduction, material and methods, results and discussion, conclusion, acknowledgment (if desired) references and summary.

\section{Subdivision}

Divide your article into clearly defined sections (Abstract, Introduction, Material and methods. etc.). Any section or subsection may be given a brief heading. Each heading should appear on its own separate line.

\section{Essential title page information}

Papers should be preceded by a title page comprising: the title, the complete name(s) of the authors, and the author's affiliations.

Title. Concise and informative. Avoid abbreviations and formulae where possible.

Author names and affiliations. Where the family name may be ambiguous (e.g., a double name), please indicate this clearly. Present the authors' affiliation addresses (where the actual work was done) below the names. Indicate all affiliations with a lower-case superscript arabic number immediately after the author's name and in front of the appropriate address. Provide the full postal address of each affiliation, including the country name of each author.

Corresponding author. Clearly indicate (with *) who will handle correspondence at all stages of refereeing and publication, also post-publication. Ensure that telephone and fax numbers (with country and area code) are provided in addition to the e-mail address and the complete postal address.

Each paper must begin with an Abstract which should not exceed more than 250 (original scientific and professional papers) or 100 (short communications) words. The abstract should state briefly the purpose of the research, the principal results and major conclusions. References should be avoided, but if essential, then cite the author(s) and year(s). Also, non-standard or uncommon abbreviations should be avoided, but if essential they must be defined at their first mention in the abstract itself. Immediately after the abstract, provide a list of 3 to 6 keywords arranged in the order according to their importance.

\section{Introduction}

State the objectives of the work and provide an adequate background, avoiding a detailed literature survey or a summary of the results.

\section{Material and methods}

Provide sufficient detail to allow the work to be reproduced. Methods already published should be indicated by a reference: only relevant modifications should be described. Manuscripts which are related to theoretical studies, instead of Material and methods, should contain a sub-heading and the Theoretical background where the necessary details for verifying the results obtained should be stated.

\section{Results}

Results should be clear and concise.

\section{Discussion}

This should explore the significance of the results of the work, not repeat them. A combined Results and Discussion section is often appropriate. Avoid extensive citations and discussion of published literature.

\section{Conclusions}

The main conclusions of the study may be presented in a short Conclusions section, which may stand alone or form a subsection of a Discussion or Results and Discussion section.

\section{Acknowledgements}

Collate acknowledgements in a separate section at the end of the article before the references and do not, therefore, include them on the title page, as a footnote to the title or otherwise. List here those individuals who provided help during the research (e.g., providing language help, writing assistance or proof reading the article, etc.).

\section{References}

\section{Citation in text}

Please ensure that every reference cited in the text is also present in the reference list (and vice versa). Any references cited in the abstract must be given in full. Unpublished results and personal communications are not recommended in the reference list, but may be mentioned in the text. If these references are included in the reference list they should follow the standard reference style of the journal and should include a substitution of the publication date with either "Unpublished results" or "Personal communication". Citation of a reference as "in press" implies that the item has been accepted for publication and a copy of the title page of the relevant article must be submitted.

\section{Web references}

As a minimum, the full URL should be given and the date when the reference was last accessed. Any further information, if known (DOI, author names, dates, reference to a source publication, etc.), should also be given. Web references can be listed separately (e.g., after the reference list) under a different heading if desired, or can be included in the reference list. 


\section{Reference style}

Text: All citations in the text should refer to:

1. Single author: the author's name (without initials, unless there is ambiguity) and the year of publication;

2. Two authors: both authors' names and the year of publication;

3. Three or more authors: first author's name followed by "et al." and the year of publication.

Citations may be made directly (or parenthetically). Groups of references should be listed first alphabetically, then chronologically.

Examples: "as demonstrated (Allan, 1996a, 1996b, 1999; Allan and Jones, 1995). Kramer et al. (2000) have recently shown...."

List: References should be arranged first alphabetically and then further sorted chronologically if necessary. More than one reference from the same author(s) in the same year must be identified by the letters "a", "b", "c", etc., placed after the year of publication.

\section{Examples:}

Reference to a journal publication:

Van der Geer, J., Hanraads, J.A.J., Lupton, R.A., 2000. The art of writing a scientific article. J. Sci. Commun. 163, 51-59.

Reference to a book:

Strunk Jr., W., White, E.B., 1979. The Elements of Style, third ed. Macmillan, New York.

Reference to a chapter in an edited book:

Mettam, G.R., Adams, L.B., 1999. How to prepare an electronic version of your article, in: Jones, B.S., Smith, R.Z. (Eds.), Introduction to the Electronic Age. E-Publishing Inc., New York, pp. 281-304.

Journal abbreviations source

Journal names should be abbreviated according to

Index Medicus journal abbreviations: http://www.nlm. nih.gov/tsd/serials/lji.html

List of serial title word abbreviations: http://www.issn. org/2-22661-LTWA-online.php;

CAS (Chemical Abstracts Service): http://www.cas. org/sent.html.

Manuscripts written in English should contain a Summary in Macedonian at the end of the paper. The summary should contain: title, author(s) full-name(s), surname(s), author's affiliations (institution and address), key words and abstract. Professional papers written in Macedonian should contain a summary in English in which the same data should be included.

\section{Submission checklist}

It is hoped that this list will be useful during the final checking of an article prior to sending it to the journal's
Editor for review. Please consult this Guide for Authors for further details of any item.

Ensure that the following items are present:

One Author designated as corresponding Author:

- E-mail address

- Telephone and fax numbers

- All necessary files have been uploaded

- Keywords

- All figure captions

- All tables (including title, description, footnotes)

- Further considerations: Manuscript has been "spellchecked" and "grammar-checked"

- $\quad$ References are in the correct format for this journal

- $\quad$ All references mentioned in the Reference list are cited in the text, and vice versa

- Permission has been obtained for use of copyrighted material from other sources (including the Web)

\section{After acceptance}

Proofs

One set of page proofs (as PDF files) will be sent by e-mail to the corresponding author. Please list the corrections and return them via e-mail. If, for any reason, this is not possible, then mark the corrections and any other comments on a printout of your proof and return by fax, or scan the pages and e-mail, or by post. Please use this proof only for checking the typesetting, editing, completeness and correctness of the text, tables and figures. Significant changes to the article as accepted for publication will not be accepted.

We will do everything possible to get your article published quickly and accurately. Therefore, it is important to ensure that all of your corrections are sent back to us in one communication: please check carefully before replying, as inclusion of any subsequent corrections cannot be guaranteed. Proofreading is solely your responsibility. Note that Macedonia Pharmaceutical Bulletin may proceed with the publication of your article if no response is received.

\section{Offprints}

The corresponding author, at no cost, will be provided with a PDF file of the article by e-mail. The PDF file is a watermarked version of the published article and includes a cover sheet with the journal cover image.

Additional paper offprints can also be ordered for an extra charge. 